Prepared in cooperation with RIO BLANCO COUNTY

\title{
Baseline Characterization of Water Quality and Mass Loading in Piceance Creek, Rio Blanco County, Colorado, December 2000
}

Water-Resources Investigations Report 02-4134

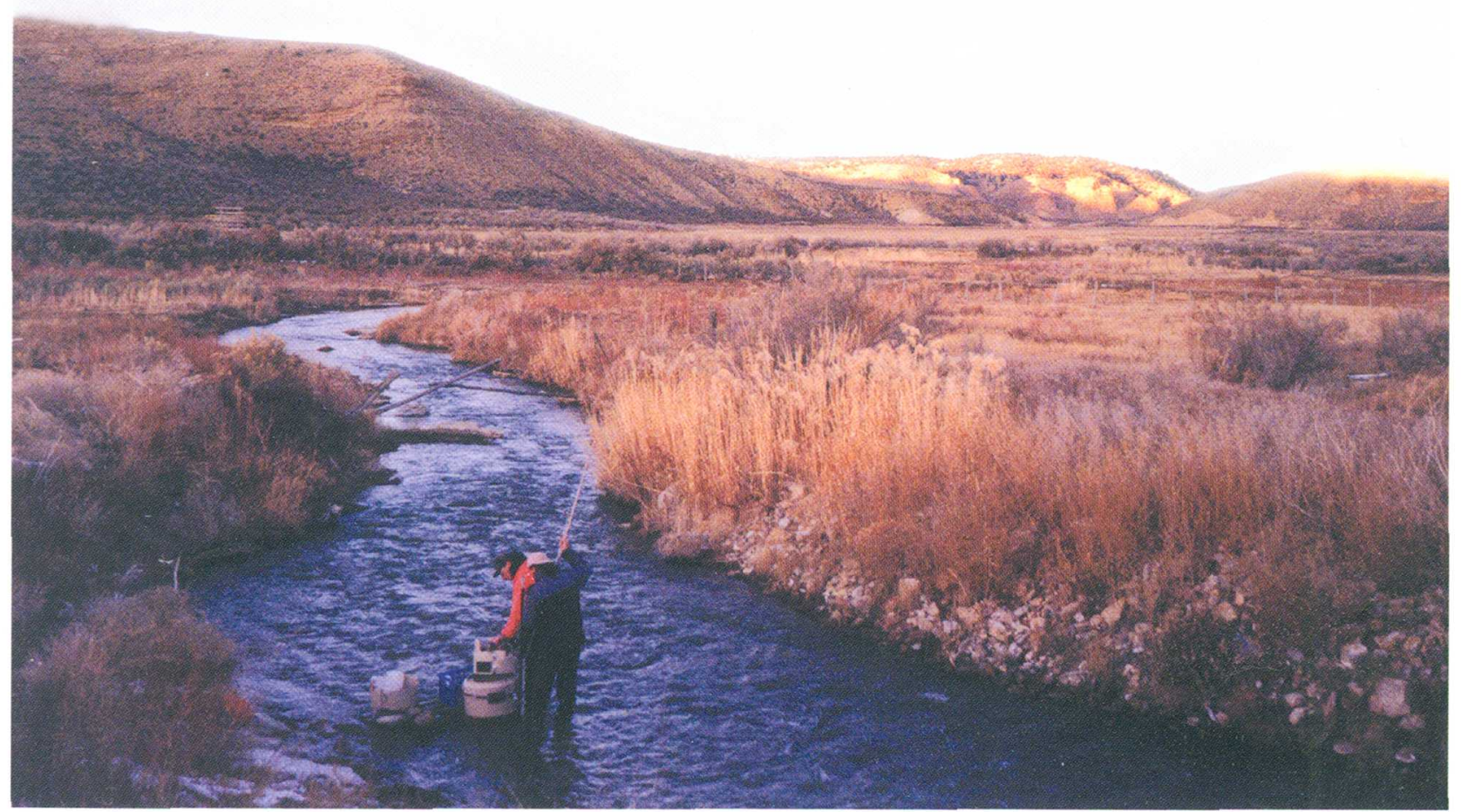

U.S. Department of the Interior U.S. Geological Survey 
Cover Photograph:

Piceance Creek looking downstream from transport site 2.

Field team retrieving tracer samples from automatic sampler.

(Photograph by Sheryl A. Ferguson, U.S. Geological Survey) 


\section{Baseline Characterization of Water Quality and Mass Loading in Piceance Creek, Rio Blanco County, Colorado, December 2000}

By Roderick F. Ortiz

U.S. GEOLOGICAL SURVEY

Water-Resources Investigations Report 02-4134

Prepared in cooperation with RIO BLANCO COUNTY 


\section{U.S. DEPARTMENT OF THE INTERIOR \\ GALE A. NORTON, Secretary}

U.S. GEOLOGICAL SURVEY

Charles G. Groat, Director

The use of firm, trade, and brand names in this report is for identification purposes only and does not constitute endorsement by the U.S. Geological Survey.

For additional information write to:

District Chief

U.S. Geological Survey

Box 25046, Mail Stop 415

Denver Federal Center

Denver, CO 80225-0046
Copies of this report can be purchased from:

U.S. Geological Survey

Information Services

Box 25286

Denver Federal Center

Denver, CO 80225 


\section{CONTENTS}

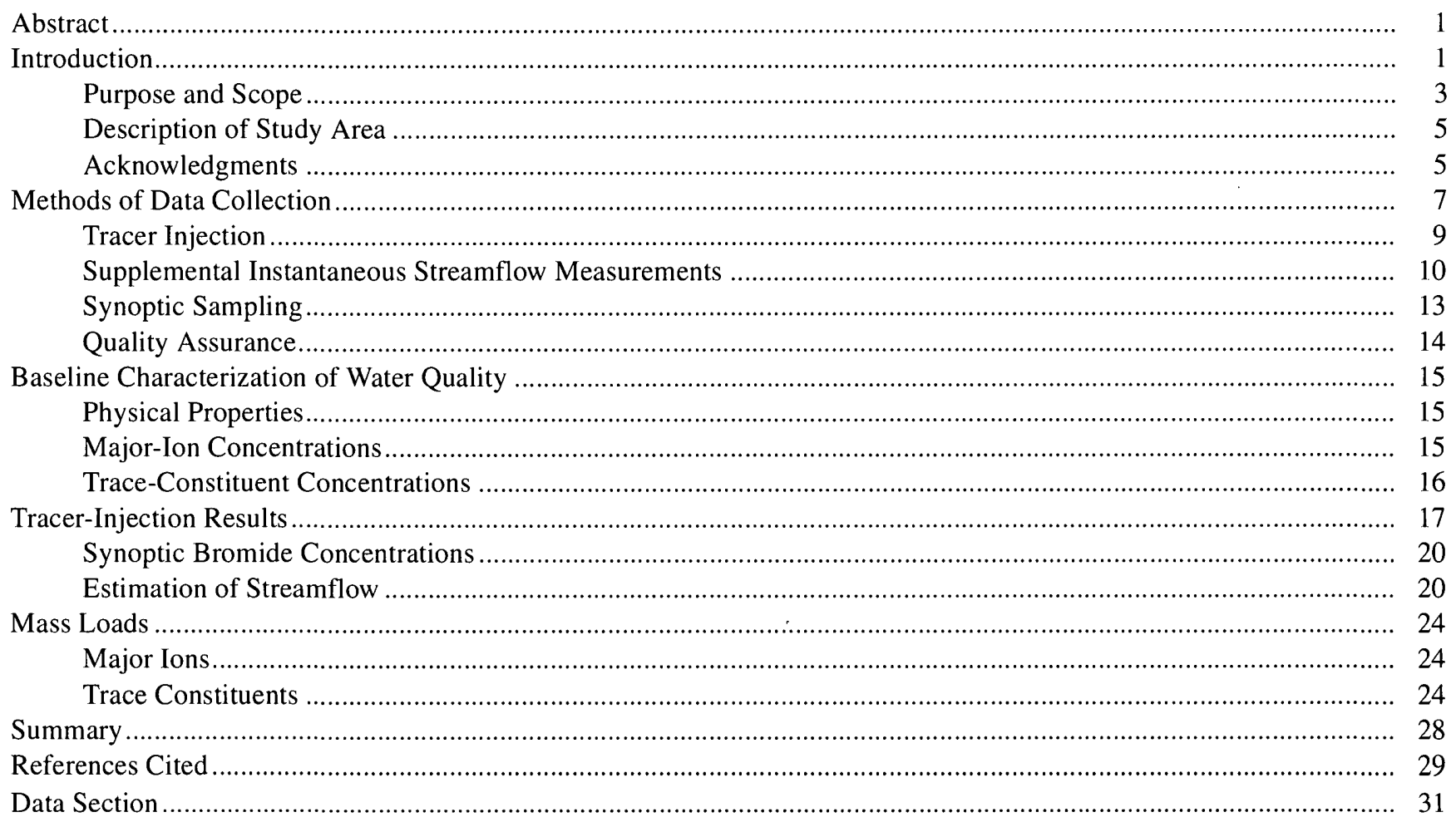

\section{FIGURES}

1. Location map of the Piceance Basin and the study area, Rio Blanco County, Colorado

2. Location map of injection and selected sampling sites in Piceance Creek and inflow sites to

Piceance Creek, December 4-7, 2000

3-16. Graphs showing:

3. Annual hydrograph at USGS streamflow-gaging stations 09306200 and 09306222

for water year 2000 .

4. Injection rates and bromide concentrations from injectate samples collected during

tracer-injection study in Piceance Creek, December 4 and 5, 2000, and December 7, $2000 \ldots \ldots \ldots \ldots \ldots \ldots \ldots . . . . . . . .10$

5. Bromide concentrations at transport sites T5 to T8 in Piceance Creek, December 4 and 5, 2000 .............. 11

6. Bromide concentrations at transport sites T1 to T4 in Piceance Creek, December 6 and 7, 2000............. 12

7. Values of pH, specific conductance, and dissolved solids in Piceance Creek, December 5-7, 2000 ........... 16

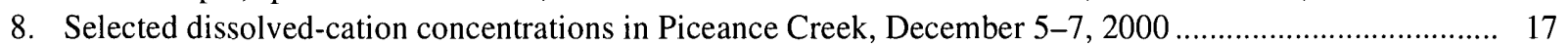

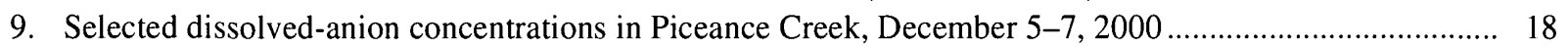

10. Selected dissolved-trace-constituent concentrations in Piceance Creek, December 5-7, 2000 .................. 19

11. Bromide concentrations and estimated streamflow at synoptic sampling sites in Piceance Creek, December 5, 2000 .

12. Bromide concentrations and estimated streamflow at synoptic sampling sites in Piceance Creek, December 7, 2000 .

13. Instanneous streamflow measurements along the primary and secondary study reaches in

Piceance Creek, December 5-7, 2000

14. Dissolved calcium, magnesium, and sodium loads in Piceance Creek, December 5-7, 2000 …............... 25

15. Dissolved bicarbonate, sulfate, and chloride loads in Piceance Creek, December 5-7, 2000.................... 26

16. Dissolved barium, boron, and strontium loads in Piceance Creek, December 5-7, 2000 …...................... 27 


\section{TABLES}

1. Site locations for tracer-dilution and synoptic-sampling study in Piceance Creek, December 4-7, 2000

2. Sequence of events during tracer-dilution and synoptic-sampling study, September 12-14, 2000, and December 3-7, 2000

3. Summary of instantaneous streamflow measurements made along the primary study reach of Piceance Creek, December 3-7, 2000.

4. Linear regression statistics for predicting dissolved solids and selected ion concentrations in Piceance Creek from specific-conductance data, December 2000

5. Chemical data for synoptic samples collected in Piceance Creek Basin, December 4-7, 2000.

6. Comparison of selected constituent concentrations for duplicate water-quality samples collected in Piceance Creek Basin, December 4-7, 2000

7. Water-quality data for field blanks processed December 5 and December 7, 2000

\section{CONVERSION FACTORS, ABBREVIATED UNITS, AND ACRONYMS}

\begin{tabular}{rll}
\hline Multiply & \multicolumn{1}{c}{ By } & To obtain \\
gram & 0.03527 & ounce \\
kilogram & 2.205 & pound \\
ton (metric) & 1.102 & ton (short) \\
micrometer & 0.0000394 & inch \\
millimeter & 0.0394 & inch \\
meter & 3.281 & feet \\
kilometer & 0.6214 & mile \\
milliliter & 0.0339 & ounce \\
liter & 0.2642 & gallon \\
square kilometer & 0.3861 & square mile \\
cubic meter & 0.000811 & acre-foot \\
liter per second & 0.03531 & cubic feet per second \\
milliliter per minute & 0.0339 & ounce per minute \\
kilogram per day & 0.0011 & ton per day \\
\hline
\end{tabular}

Temperature in degrees Celsius $\left({ }^{\circ} \mathrm{C}\right)$ may be converted to degrees Fahrenheit $\left({ }^{\circ} \mathrm{F}\right)$ as follows:

$$
{ }^{\circ} \mathrm{F}=9 / 5^{\circ} \mathrm{C}+32
$$

Sea level: In this report, "sea level" refers to the National Geodetic Vertical Datum of 1929 (NGVD of 1929)—a geodetic datum derived from a general adjustment of the first-order level nets of both the United States and Canada, formerly called Sea Level Datum of 1929.

Specific conductance is given in microsiemens per centimeter at 25 degrees Celsius $\left(\mu \mathrm{S} / \mathrm{cm}\right.$ at $\left.25^{\circ} \mathrm{C}\right)$.

Concentrations of chemical constituents in water are given either in milligrams per liter $(\mathrm{mg} / \mathrm{L})$ or micrograms per liter $(\mu \mathrm{g} / \mathrm{L})$.

\section{ABBREVIATED UNITS USED IN THIS REPORT}

$\mathrm{L} / \mathrm{s} \quad$ liter per second

s.u. $\quad$ standard units

$\mathrm{pCi} / \mathrm{L} \quad$ picocurie per liter 


\section{ACRONYMS USED IN THIS REPORT}

$\begin{array}{ll}\text { BLM } & \text { Bureau of Land Management } \\ \text { USGS } & \text { U.S. Geological Survey } \\ \text { RPR } & \text { Relative percent difference } \\ \text { NWQL } & \text { National Water Quality Laboratory } \\ \mathrm{NaBr} & \text { Sodium Bromide } \\ \mathrm{LiBr} & \text { Lithium Bromide }\end{array}$





\title{
Baseline Characterization of Water Quality and Mass Loading in Piceance Creek, Rio Blanco County, Colorado, December 2000
}

\author{
By Roderick F. Ortiz
}

\begin{abstract}
Data collected by the U.S. Geological Survey provided a baseline characterization of the water quality in Piceance Creek and quantified the mass load for selected chemical constituents in Piceance Creek during base-flow conditions. Tracer-dilution techniques and instantaneous measurements were used to determine streamflow in Piceance Creek. Synopticsampling techniques were used to determine baseline concentrations for selected constituents. Load profiles along subreaches of the creek were generated by combining tracer-dilution and synoptic-sampling techniques.

Data collected as part of this study provide an updated characterization of the water quality in Piceance Creek along the 28-kilometer study reach. In 1987 , bicarbonate, sulfate, and sodium were reported as the principal dissolved constituents in Piceance Creek. The principal dissolved constituents remained the same in December 2000. High concentrations of bicarbonate and sodium result from the contact of ground water with evaporite minerals in the Green River Formation. Sulfate is commonly found in high concentrations in the ground water of the overlying Uinta Formation. Concentrations of barium, boron, lithium, and strontium also were elevated in Piceance Creek. No significant load input to Piceance Creek was detected along the reach adjacent to the boundary of the Yankee Gulch Lease (primary study reach). Although the area near Alkali Flat contributed substantially to the increase in constituent concentration in Piceance Creek, losses in streamflow resulted in relatively small increases in load downstream to the end of the study reach.
\end{abstract}

\section{INTRODUCTION}

The Piceance Creek Basin is a downwarped, depositional region located in northwestern Colorado (fig. 1). The structural basin was formed during the Laramide orogeny, a mountain-building process of thrusting, faulting, and folding that lasted at least 10 million years from Late Cretaceous to Eocene time (Maclachlan, 1987). About 48 million years ago, an ancient lake (Lake Uinta) covered thousands of square kilometers of Colorado, Utah, and Wyoming. At its maximum size, Lake Uinta covered about 57,000 square kilometers, including the Piceance structural basin. Vast quantities of oil shale accumulated as organic-rich marls in the deeper part of the lake. Evaporite minerals such as sodium, bicarbonate, and chloride also precipitated in the oil-rich marlstones as brine concentrations exceeded the solubility limits of these minerals. When downwarping ceased, the basin filled with sediments and Lake Uinta disappeared (Dyni, 1987).

The marlstone of the Green River Formation in the Piceance Basin is a repository for one of the largest energy reserves in the world (Donnell, 1987). For nearly a century, the area has been known for its rich oil-shale deposits. From 1950 to 1990, concentrated efforts were made by the federal government and the oil industry to locate and develop the oil-shale reserves as alternative energy sources. These efforts were never fully realized.

Other potentially valuable minerals also are abundant in the oil-shale deposits. Nahcolite, a sodium bicarbonate mineral; dawsonite, a sodium aluminum carbonate mineral; and halite, sodium chloride, are interspersed through the lower part of the oil-shale deposits. In recent years, the emphasis of resource development in the Piceance Creek Basin has turned to 


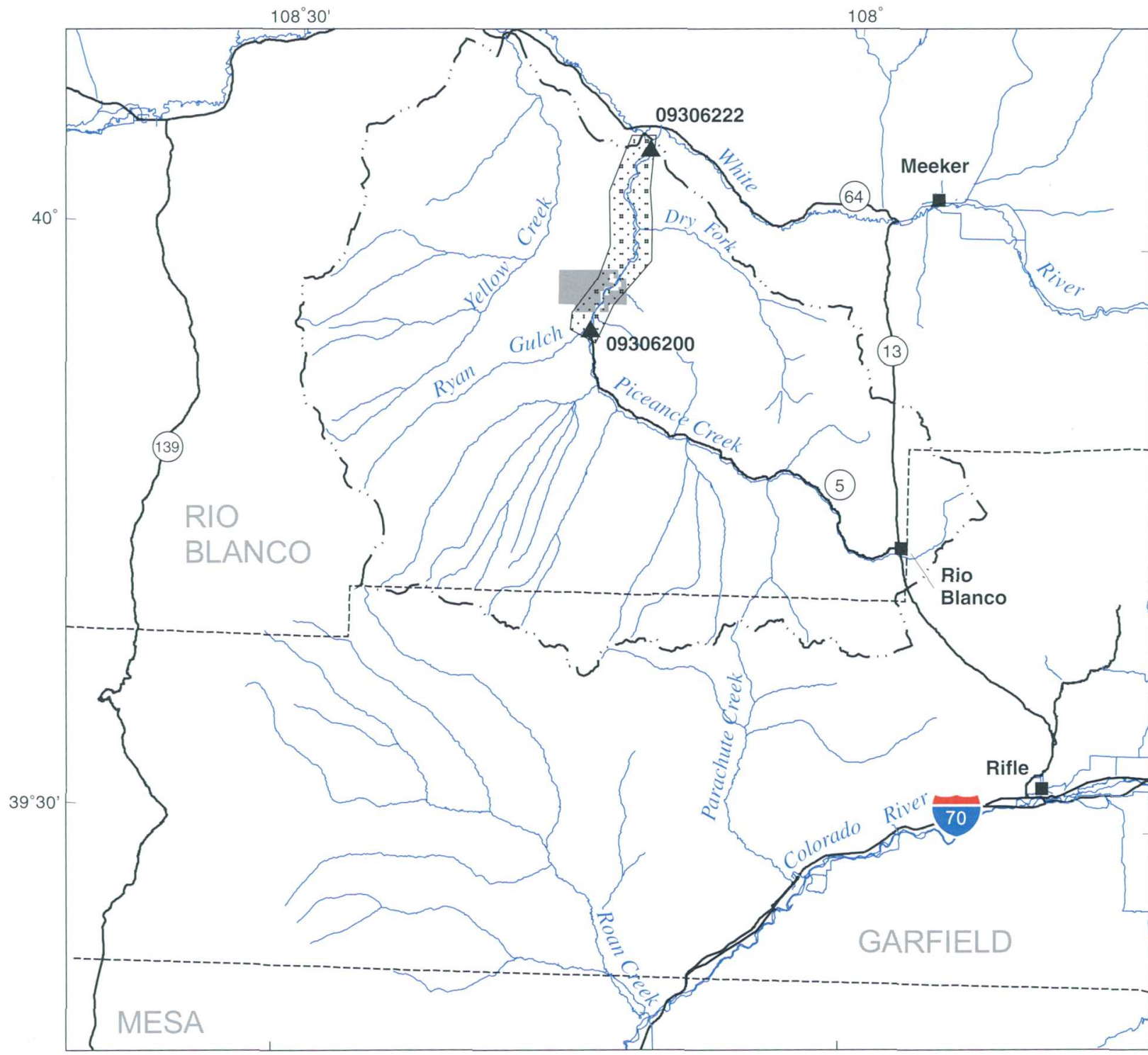

Hydrology modified by Denver Water Board 1998

from U.S. Geological Survey Digital Line Graphs 1:100,000, 1981-82.

Albers Equal-Area projection

Standard parallels $37^{\circ} 30^{\prime} \mathrm{N}$ and $40^{\circ} 30^{\prime} \mathrm{N}$

Central Meridian $105^{\circ} 30^{\prime} \mathrm{W}$
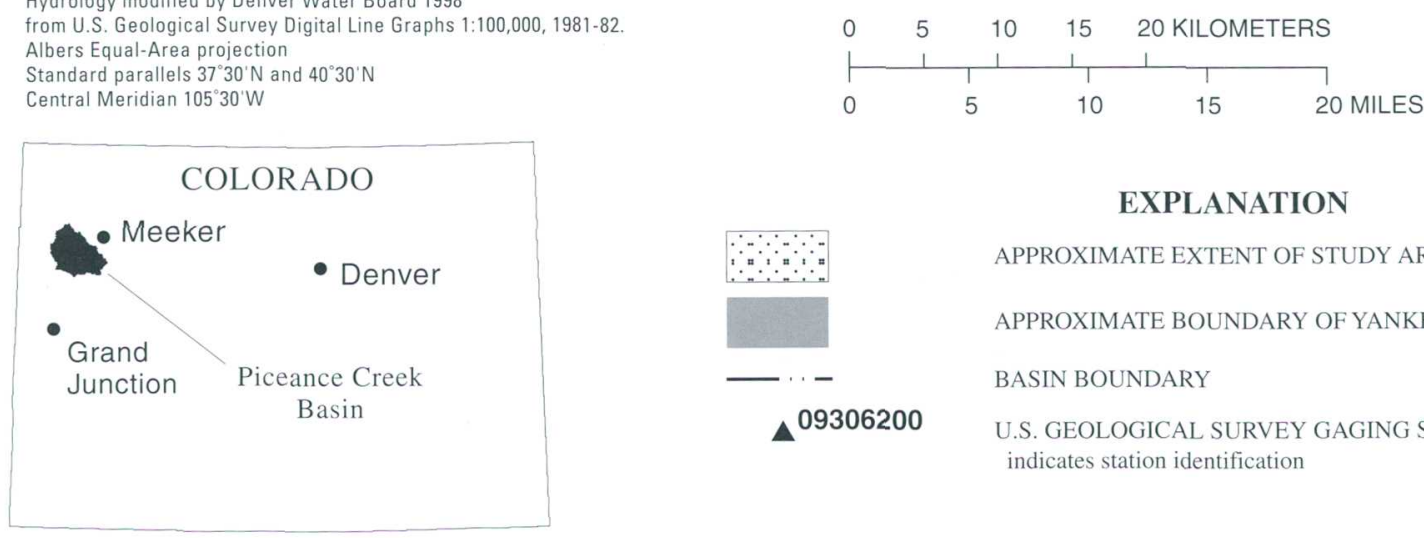

EXPLANATION

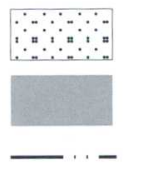

09306200
APPROXIMATE EXTENT OF STUDY AREA

APPROXIMATE BOUNDARY OF YANKEE GULCH LEASE

BASIN BOUNDARY

U.S. GEOLOGICAL SURVEY GAGING STATIONS-Number indicates station identification

Figure 1. Location of the Piceance Basin and the study area, Rio Blanco County, Colorado. 
commercial nahcolite solution mining for sodium bicarbonate (baking soda) and sodium carbonate (soda ash). The Piceance Basin is reported to have the largest and most economically significant nahcolite resources in the world (Beard and others, 1974). Conservative estimates of in-place nahcolite have been reported at 26 billion metric tons.

In 1999, the U.S. Bureau of Land Management (BLM) issued a Draft Environmental Impact Statement that evaluated the effects of a commercial nahcolite solution mining operation on the Yankee Gulch Joint-Venture Lease (fig. 1) within the BLM's White River Resource Area (U.S. Bureau of Land Management, 1999). The Yankee Gulch Sodium Minerals Project (Yankee Gulch Project) would occur at this site about 37 kilometers southwest of Meeker, Colorado (fig. 1). As part of the permitting and regulatory requirements, the mine operators were required to submit a monitoring plan that, in part, would characterize the baseline water quality in the adjacent Piceance Creek (Agapito Associates, Inc., 1999). The primary objective of the baseline characterization, of which this study is a part, is to provide the baseline data needed to assess possible changes in the water quality of Piceance Creek due to continued mining operations. The U.S. Geological Survey (USGS) provided this characterization in cooperation with Rio Blanco County, Colorado.

\section{Purpose and Scope}

The purpose of this report is to (1) provide a baseline characterization of the water quality in Piceance Creek, and (2) quantify the mass load for selected chemical constituents in Piceance Creek during base-flow conditions. Physical and chemical data were collected during the week of December 3-8, 2000, at 47 main-stem sites and 4 inflow sites (table 1). Several quality-assurance samples also were collected. The study reach extended about 28 kilometers between the USGS streamflowgaging stations 09306200 (Ryan Gulch station, PC0) and 09306222 (White River station, PC28,348) on Piceance Creek (fig. 1). The primary focus of the study was along the approximately 11.5 kilometers of the study area adjacent to the lease boundary for the Yankee Gulch Project (primary study reach).

Table 1. Site locations for tracer-dilution and synoptic-sampling study in Piceance Creek, December 4-7, 2000

[s.u., standard units; $\mu \mathrm{S} / \mathrm{cm}$, microsiemens per centimeter; ${ }^{\circ} \mathrm{C}$, degrees Celsius; USGS, U.S. Geological Survey; Y, yes; N, no; NA, not applicable; e, estimated; $\mathrm{LiBr}$, lithium bromide; $\mathrm{NaBr}$, sodium bromide]

\begin{tabular}{|c|c|c|c|c|c|c|c|}
\hline \multirow{2}{*}{$\begin{array}{c}\text { Site } \\
\text { number }\end{array}$} & \multirow{2}{*}{$\begin{array}{l}\text { Distance from } \\
\text { streamflow- } \\
\text { gaging station } \\
09306200 \\
\text { (meters) }\end{array}$} & \multicolumn{2}{|c|}{ Sample collection } & \multirow[b]{2}{*}{$\begin{array}{c}\text { pH } \\
\text { (s.u.) }\end{array}$} & \multirow{2}{*}{$\begin{array}{c}\text { Specific } \\
\text { conductance } \\
(\mu \mathrm{S} / \mathrm{cm} \text { at } \\
\left.25^{\circ} \mathrm{C}\right)\end{array}$} & \multirow{2}{*}{$\begin{array}{c}\text { Back- } \\
\text { ground } \\
\text { bromide } \\
\text { sample } \\
\text { collected }\end{array}$} & \multirow[b]{2}{*}{ Site type designation } \\
\hline & & Date & Time & & & & \\
\hline \multicolumn{8}{|c|}{ Main-stem Piceance Creek sites } \\
\hline $\mathrm{PC} 0$ & 0 & $12-07-00$ & 1040 & 8.0 & 1,540 & NA & $\begin{array}{l}\text { Background, USGS streamflow-gaging } \\
\text { station 09306200, LiBr injection site }\end{array}$ \\
\hline PC180 & 180 & $12-07-00$ & 1035 & 8.0 & 1,590 & $\mathrm{~N}$ & Routine, transport site $\mathrm{T} 1$ \\
\hline PC420 & 420 & $12-07-00$ & 1030 & 8.0 & 1,590 & $\mathrm{Y}$ & Routine \\
\hline PC660 & 660 & $12-07-00$ & 1020 & 8.0 & 1,600 & $\mathrm{~N}$ & Routine \\
\hline PC 1,080 & 1,080 & $12-07-00$ & 1015 & 8.1 & 1,610 & $\mathrm{~N}$ & Routine \\
\hline PC 1,320 & 1,320 & $12-07-00$ & 1005 & 8.1 & 1,610 & $\mathrm{~N}$ & Routine \\
\hline PC 1,560 & 1,560 & $12-07-00$ & 0955 & 8.1 & 1,610 & $\mathrm{Y}$ & Routine \\
\hline PC 1,960 & 1,960 & $12-07-00$ & 0945 & 8.1 & 1,610 & $\mathrm{~N}$ & Routine \\
\hline PC2,205 & 2,205 & $12-07-00$ & 0935 & 8.1 & 1,600 & Y & Indicator, transport site $\mathrm{T} 2$, quality control \\
\hline $\mathrm{PC} 2,445$ & 2,445 & $12-07-00$ & 0925 & 8.1 & 1,610 & $\mathrm{~N}$ & Routine \\
\hline PC2,685 & 2,685 & $12-07-00$ & 0920 & 8.0 & 1,620 & $\mathrm{~N}$ & Routine \\
\hline PC2,925 & 2,925 & $12-07-00$ & 0910. & 8.0 & 1,630 & $\mathrm{~N}$ & Routine \\
\hline PC3,105 & 3,105 & $12-07-00$ & 0900 & 8.0 & 1,630 & Y & Routine \\
\hline
\end{tabular}


Table 1. Site locations for tracer-dilution and synoptic-sampling study in Piceance Creek, December 4-7, 2000-Continued

[s.u., standard units; $\mu \mathrm{S} / \mathrm{cm}$, microsiemens per centimeter; ${ }^{\circ} \mathrm{C}$, degrees Celsius; USGS, U.S. Geological Survey; Y, yes; N, no; NA, not applicable; e, estimated; $\mathrm{LiBr}$, lithium bromide; $\mathrm{NaBr}$, sodium bromide]

\begin{tabular}{|c|c|c|c|c|c|c|c|}
\hline \multirow{2}{*}{$\begin{array}{c}\text { Site } \\
\text { number }\end{array}$} & \multirow{2}{*}{$\begin{array}{l}\text { Distance from } \\
\text { streamflow- } \\
\text { gaging station } \\
09306200 \\
\text { (meters) }\end{array}$} & \multicolumn{2}{|c|}{ Sample collection } & \multirow{2}{*}{$\begin{array}{c}\text { pH } \\
\text { (s.u.) }\end{array}$} & \multirow{2}{*}{$\begin{array}{l}\text { Specific } \\
\text { conductance } \\
(\mu \mathrm{S} / \mathrm{cm} \text { at } \\
\left.25^{\circ} \mathrm{C}\right)\end{array}$} & \multirow{2}{*}{$\begin{array}{c}\text { Back- } \\
\text { ground } \\
\text { bromide } \\
\text { sample } \\
\text { collected }\end{array}$} & \multirow{2}{*}{ Site type designation } \\
\hline & & Date & Time & & & & \\
\hline \multicolumn{8}{|c|}{ Main-stem Piceance Creek sites-Continued } \\
\hline PC 3,278 & 3,278 & $12-07-00$ & 0845 & 8.0 & 1,630 & $\mathrm{~N}$ & Routine \\
\hline PC 3,505 & 3,505 & $12-07-00$ & 0835 & 8.0 & 1,640 & $\mathrm{Y}$ & Routine, quality control \\
\hline PC 3,735 & 3,735 & $12-07-00$ & 0825 & 8.1 & 1,650 & $\mathrm{~N}$ & Routine \\
\hline PC3,935 & 3,935 & $12-07-00$ & 0815 & 8.1 & 1,640 & $\mathrm{Y}$ & Routine \\
\hline PC4,180 & 4,180 & $12-07-00$ & 0800 & 8.0 & 1,630 & $\mathrm{Y}$ & Indicator, transport site $\mathrm{T} 3$ \\
\hline $\mathrm{PC} 4,420$ & 4,420 & $12-07-00$ & 0755 & 8.0 & 1,630 & $\mathrm{~N}$ & Routine \\
\hline PC4,660 & 4,660 & $12-07-00$ & 0745 & 8.0 & 1,630 & $\mathrm{Y}$ & Routine \\
\hline PC4,900 & 4,900 & $12-07-00$ & 0735 & 8.0 & 1,640 & $\mathrm{~N}$ & Routine \\
\hline PC 5,040 & 5,040 & $12-07-00$ & 0727 & 8.1 & 1,630 & $\mathrm{~N}$ & Routine \\
\hline PC5,280 & 5,280 & $12-07-00$ & 0700 & 8.0 & 1,590 & $\mathrm{~N}$ & Indicator, transport site $\mathrm{T} 4$ \\
\hline PC6,625 & 6,625 & $\begin{array}{l}12-05-00 \\
12-07-00\end{array}$ & $\begin{array}{l}1040 \\
1147\end{array}$ & $\begin{array}{l}8.0 \\
8.1\end{array}$ & $\begin{array}{l}1,680 \\
1,690\end{array}$ & $\begin{array}{l}\mathrm{Y} \\
\mathrm{N}\end{array}$ & $\begin{array}{c}\text { Background, } \mathrm{NaBr} \text { injection site } \\
\text { Quality assurance }\end{array}$ \\
\hline PC6,813 & 6,813 & $12-05-00$ & 1020 & 8.0 & 1,690 & $\mathrm{Y}$ & Routine, transport site T5 \\
\hline PC 7,028 & 7,028 & $12-05-00$ & 1010 & 8.0 & 1,690 & Y & Routine \\
\hline PC7,248 & 7,248 & $12-05-00$ & 0955 & 8.0 & 1,700 & $\mathrm{Y}$ & Routine \\
\hline PC7,498 & 7,498 & $12-05-00$ & 0945 & 8.0 & 1,680 & $\mathrm{~N}$ & Routine \\
\hline PC7,738 & 7,738 & $12-05-00$ & 0935 & 8.0 & 1,690 & $\mathrm{Y}$ & Routine \\
\hline PC7,978 & 7,978 & $12-05-00$ & 0930 & 8.0 & 1,710 & $\mathrm{~N}$ & Routine \\
\hline PC8,098 & 8,098 & $12-05-00$ & 0915 & 8.1 & 1,700 & $\mathrm{Y}$ & Indicator, transport site $\mathrm{T} 6$, quality control \\
\hline PC 8,448 & 8,448 & $12-05-00$ & 0905 & 8.0 & 1,720 & $\mathrm{Y}$ & Routine, quality control \\
\hline PC 8,688 & 8,688 & $12-05-00$ & 0855 & 8.0 & 1,730 & Y & Routine \\
\hline PC8,938 & 8,938 & $12-05-00$ & 0850 & 8.0 & 1,720 & $\mathrm{Y}$ & Routine \\
\hline PC9,298 & 9,298 & $12-05-00$ & 0825 & 8.0 & 1,720 & $\mathrm{Y}$ & Routine \\
\hline PC9,608 & 9,608 & $12-05-00$ & 0815 & 8.0 & 1,700 & $\mathrm{Y}$ & Routine \\
\hline PC9,938 & 9,938 & $12-05-00$ & 0805 & 8.0 & 1,740 & $\mathrm{Y}$ & Routine, transport site T7 \\
\hline $\mathrm{PC} 10,328$ & 10,328 & $12-05-00$ & 0800 & 8.0 & 1,730 & $\mathrm{Y}$ & Routine \\
\hline $\mathrm{PC} 10,748$ & 10,748 & $12-05-00$ & 0745 & 8.0 & 1,730 & $\mathrm{Y}$ & Routine \\
\hline PC1 1,483 & 11,483 & $12-05-00$ & 0730 & 8.1 & 1,720 & $\mathrm{Y}$ & Indicator, transport site $\mathrm{T} 8$ \\
\hline $\mathrm{PC} 14,789$ & 14,789 & $12-06-00$ & 1005 & 8.0 & 1,780 & NA & Routine \\
\hline $\mathrm{PC} 16,210$ & 16,210 & $12-06-00$ & 0910 & 8.0 & 1,770 & NA & Routine \\
\hline $\mathrm{PC} 17,860$ & 17,860 & $12-06-00$ & 0805 & 8.1 & 1,710 & NA & Indicator \\
\hline PC20,708 & 20,708 & $12-06-00$ & 1030 & 8.0 & 1,730 & NA & Routine \\
\hline PC23,721 & 23,721 & $12-06-00$ & 0945 & 8.0 & 1,980 & NA & Indicator \\
\hline PC24,787 & 24,787 & $12-06-00$ & 0900 & 7.9 & 1,950 & NA & Routine \\
\hline PC28,348 & 28,348 & $12-06-00$ & 0745 & 8.0 & 1,980 & NA & Routine, USGS station 09306222 \\
\hline \multicolumn{8}{|c|}{ Inflows and springs } \\
\hline RGS & $\mathrm{e} 200$ & $12-04-00$ & 0900 & 7.8 & 3,060 & NA & Ryan Gulch spring \\
\hline HGS & e 1,625 & $12-07-00$ & 1220 & 8.0 & 3,510 & NA & Spring contact near Hatch Gulch \\
\hline PT 16,225 & e16,225 & $12-06-00$ & 0925 & 8.0 & 1,150 & NA & Dry Fork \\
\hline AFS & $\mathrm{e} 21,288$ & $12-04-00$ & 1225 & 7.8 & 12,700 & NA & Alkali Flat spring contacts \\
\hline
\end{tabular}


Tracer-dilution techniques were used to develop a spatial streamflow profile along the primary study reach. This reach is close to the Yankee Gulch Project, a nahcolite-solution mining operation that could possibly affect the water quality of the creek. A less detailed streamflow profile was developed along the lower two-thirds of the study reach (secondary study reach) by using standard USGS streamflow-measurement techniques (Rantz and others, 1982). Synoptic water-quality samples were collected along both study reaches to establish baseline constituent concentrations and to calculate mass loading in Piceance Creek.

\section{Description of Study Area}

The study area described in this report extends between the Ryan Gulch streamflow-gaging station (PC0) and the White River streamflow-gaging station (PC28,348) (fig. 2). Sites were identified by a downstream distance in meters from the PC0. The study area encompasses about 235 square kilometers of drainage area (Crowfoot and others, 2001). Streamchannel elevations range from 1,850 to 1,746 meters above sea level. The highest elevation in the study area is nearly 2,400 meters. Generally, streamflow increases downstream during base-flow conditions from October to April; streamflows are more similar during the irrigation season (fig. 3). Tobin (1987), however, identified a subreach downstream from Dry Fork where streamflow decreased. An estimated 80 percent of the annual runoff in the watershed occurs during base-flow conditions, and springs are an important contributor to streamflow during this period (Robson and Saulnier, 1981). Most of the tributaries to Piceance Creek are ephemeral; Dry Fork was the only surface-water inflow to Piceance Creek measured during the December 2000 field activities (fig. 2). Because of the large number of sites sampled as part of this study, only sample sites specifically addressed in this report are shown in figure 2.

Piceance Creek is characterized by a meandering stream channel incised into the floodplain with deep bank carving that is prone to sloughing. As such, sediment loads to the stream can be considerable during high runoff (Norman, 1987). The streambed is composed of silt, sand, gravel, and occasional cobbles. Pockets of fine material are deposited where slow stream velocity occurs. Although lakes and reservoirs are not abundant in the Piceance Creek Basin, a small irrigation/wildlife impoundment is located in the study reach (fig. 2). Typically, impoundments such as these are less than 4.5 meters in depth and are prone to siltation (U.S. Bureau of Land Management, 1984). The gentle slope of the stream valley provides an area well suited for sub-irrigated or flood-irrigated agricultural production. Irrigation is prevalent from May through mid-October in the relatively narrow (300 to 380 meters wide) alluvial valley. The predominant crops are alfalfa and grass hay for livestock (U.S. Bureau of Land Management, 1984). The climate in the area is characterized by low humidity, sunny days, clear nights, little precipitation, extreme evaporation, and large diurnal temperature changes (U.S. Bureau of Land Management, 1984). The mean daily air temperature during December 2000 at Rifle, Colorado (fig. 1), ranged from -8 to 2 degrees Celsius (Colorado Climate Center, 2001). Stream temperatures during the field activities were routinely near freezing, and ice was observed along much of the streambank of Piceance Creek.

The valleys of the White River (fig. 2) and its tributaries are partly filled with alluvium and fan deposits consisting of sand and gravel. However, test holes drilled downstream from Ryan Gulch (fig. 1) penetrated about 21 meters of clay interbedded with sand and gravel, which indicates deposition in a lake environment (Welder, 1987). The frequency of occurrence of such clay beds is unknown. Downstream water movement in these less permeable aquifers is restricted, which forces the water to discharge as springs. Springs that maintain the streamflow throughout the year are found along the upper reaches of Piceance Creek including Ryan Gulch, where water-bearing marlstones of the Green River Formation intersect the valley of Piceance Creek (Saulnier and Ford, 1977). Springs in the area also may be supplied directly by water discharging from the bedrock aquifers through fractures (Welder, 1987). The complex fracture system in the Piceance Creek Basin has been extensively studied and is the primary conduit through which ground water flows through the bedrock aquifers of the basin (Grout and Verbeek, 1985; Verbeek and Grout, 1983a, 1983b, and 1987).

\section{Acknowledgments}

The author acknowledges the many individuals who assisted in this study. Particular thanks are 


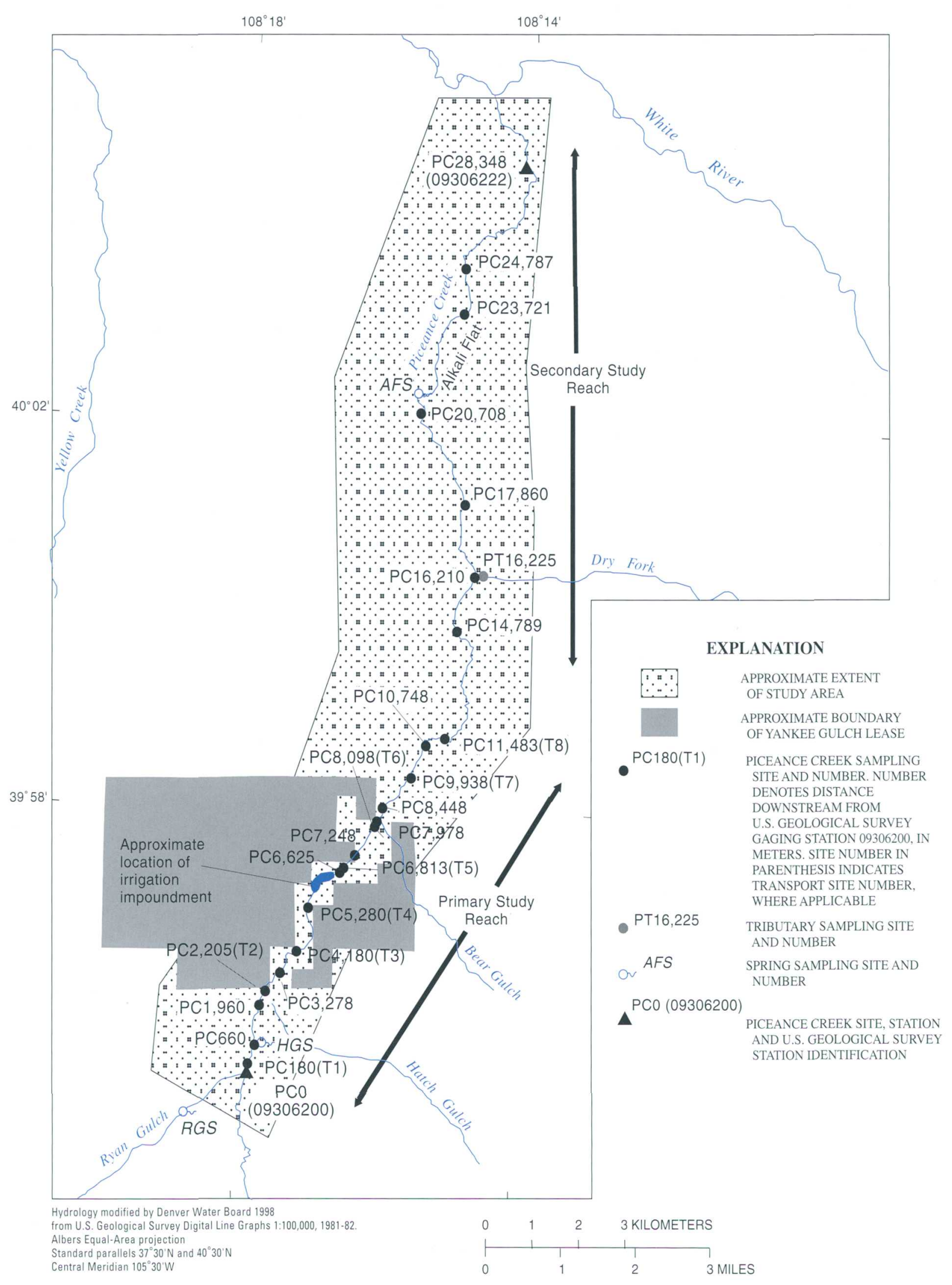

Figure 2. Location of injection and selected sampling sites in Piceance Creek and inflow sites to Piceance Creek, December 4-7, 2000 


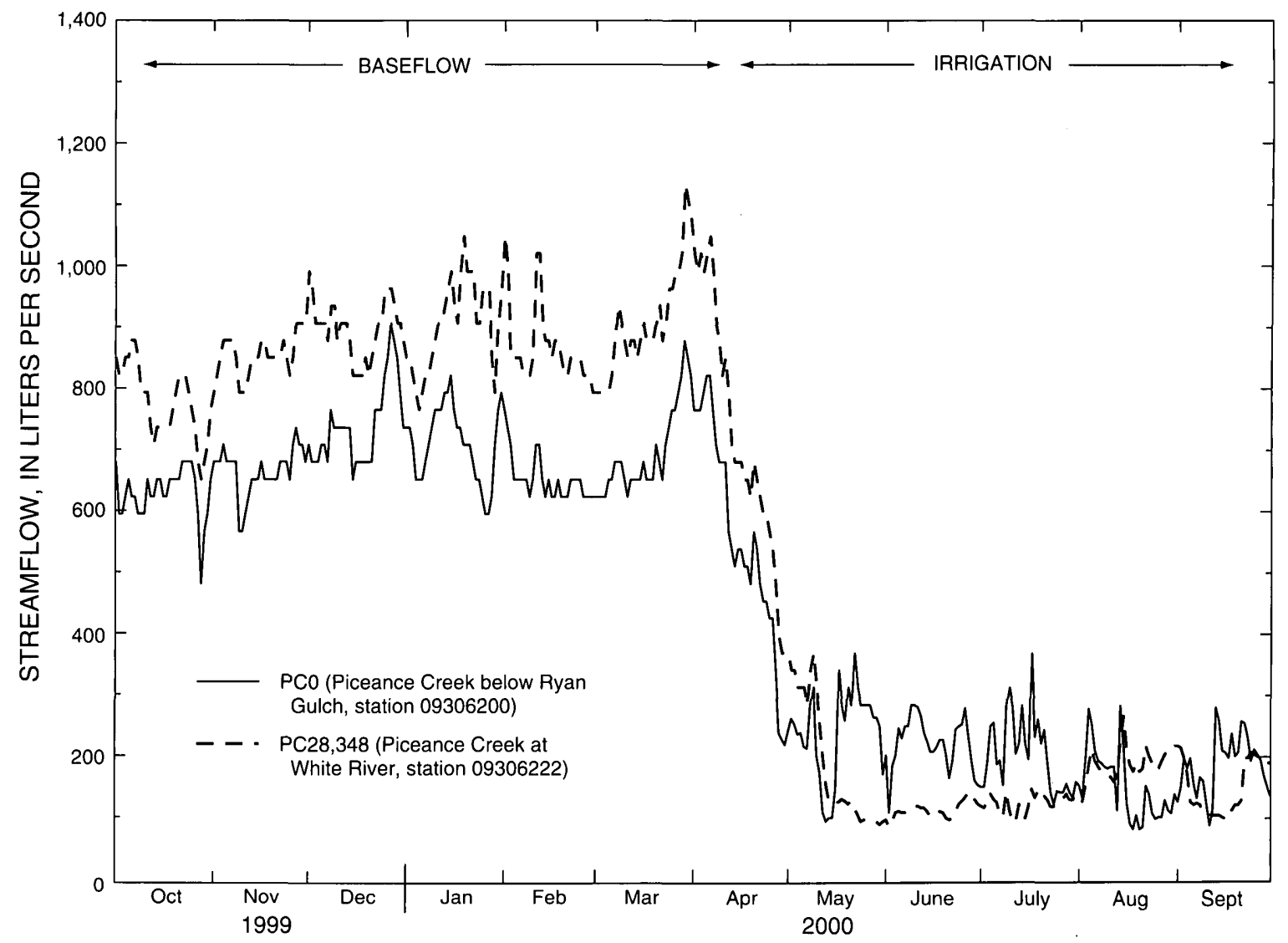

Figure 3. Annual hydrograph at USGS streamflow-gaging stations 09306200 and 09306222 for water year 2000 .

extended to George J. Saulnier, Jr., of Duke Engineering and Celina Akin of American Soda, LLP, for sharing their insight and knowledge of the study area. Individuals assisting in the collection of water-quality, hydrologic, or geologic data are acknowledged and include: Tom Young and Willard Phillips of American Soda, LLP and volunteer Mary Leib. The author also would like to acknowledge the contributions of Daniel L. Brendle, Russell G. Dash, Joseph R. Dungan, Sheryl A. Ferguson, Kenneth J. Leib, Robert L. Runkel, Robert W. Stogner, Sr., Kenneth R. Watts, and Douglas B. Yager of the USGS.

\section{METHODS OF DATA COLLECTION}

This study was designed to determine streamflow and baseline-chemical quality at numerous mainstem sites in Piceance Creek. Tracer-dilution tech- niques and instantaneous streamflow measurements were used to determine streamflow. Synopticsampling techniques were used to determine concentrations for selected constituents in Piceance Creek. Load profiles along subreaches of the creek were generated by combining tracer-dilution and synopticsampling techniques (Kimball, 1997).

A general overview of the field activities is described here. A more detailed account can be found in table 2 and in the following sections of this report. The study area was divided into two areas of investigation. The upper one-third of the study area (primary study reach) was investigated by using tracer-dilution and synoptic-sampling techniques. About 85 percent of the total sites were located along the primary study reach to provide a detailed understanding of the baseline concentrations near the Yankee Gulch Project. The primary study reach was divided further into two separate tracer-dilution experiments for logistical 
Table 2. Sequence of events during tracer-dilution and synoptic-sampling study, September 12-14, 2000, and December 3-7, 2000

[NA, not applicable; $\mathrm{NaBr}$, sodium bromide; $\mathrm{LiBr}$, lithium bromide]

\begin{tabular}{|c|c|c|}
\hline $\begin{array}{l}\text { Start } \\
\text { date }\end{array}$ & $\begin{array}{l}\text { Approximate } \\
\text { start time }\end{array}$ & Activity \\
\hline $9-12-00$ to $9-14-00$ & NA & Reconnaissance to determine location of injection sites and stream sampling sites. \\
\hline \multirow[t]{4}{*}{$12-03-00$} & 0800 & Collection of background bromide samples between PC6,625 and PC11,483. \\
\hline & 0830 & Estimation of traveltimes between PC6,625 and PC11,483. \\
\hline & 1200 & Preparation of $\mathrm{NaBr}$ solution. \\
\hline & 1400 & Installation of automatic samplers at designated transport sites. \\
\hline \multirow[t]{3}{*}{$12-04-00$} & 0800 & $\begin{array}{l}\text { Start of } \mathrm{NaBr} \text { injection and automatic samplers downstream from PC6,625. } \\
\text { Collection of background bromide samples between PC0 and PC5,280. }\end{array}$ \\
\hline & 0830 & Estimation of traveltimes between PC0 and PC5,280. \\
\hline & 1000 & Collection and processing of water-quality samples collected at inflow sites. \\
\hline \multirow[t]{4}{*}{$12-05-00$} & 0730 & $\begin{array}{l}\text { Collection and processing of synoptic water-quality samples from PC1 1,483 to PC6,625. } \\
\text { Collection of bromide samples by hand in response to difficulties with automatic samplers. } \\
\text { Start of instantaneous streamflow measurements along reach. }\end{array}$ \\
\hline & 1100 & $\begin{array}{l}\text { End of synoptic water-quality sampling and } \mathrm{NaBr} \text { injection. } \\
\text { Relocation of injection equipment to upper injection site. }\end{array}$ \\
\hline & 1200 & $\begin{array}{l}\text { Preparation of } \mathrm{LiBr} \text { solution. } \\
\text { End of instantaneous streamflow measurements along reach. }\end{array}$ \\
\hline & 1830 & End of bromide sampling at furthest downstream transport site in reach $(\mathrm{PC} 11,483)$. \\
\hline \multirow[t]{4}{*}{$12-06-00$} & 0730 & $\begin{array}{l}\text { Collection and processing of synoptic water-quality samples and instantaneous streamflow } \\
\text { measurements from PC } 28,348 \text { (USGS } 09306222 \text { ) to PC20,708 (team 1). } \\
\text { Collection and processing of synoptic water-quality samples and instantaneous streamflow } \\
\text { measurements from PC } 17,860 \text { to PC14,789 (team 2). }\end{array}$ \\
\hline & 0800 & $\begin{array}{l}\text { Start of } \mathrm{LiBr} \text { injection downstream from } \mathrm{PC} 0 \text {. } \\
\text { Collection of bromide samples by hand in response to difficulties with automatic samplers. }\end{array}$ \\
\hline & 1030 & End of water-quality sampling along secondary study reach by all teams. \\
\hline & 1800 & Initialization of automatic samplers for limited sample collection during night. \\
\hline \multirow[t]{4}{*}{$12-07-00$} & 0730 & $\begin{array}{l}\text { Collection and processing of synoptic water-quality samples from PC5,280 to PC0. } \\
\text { Collection of bromide samples by hand in response to difficulties with automatic samplers } \\
\text { Start of instantaneous streamflow measurements along reach. }\end{array}$ \\
\hline & 1100 & End of synoptic water-quality sampling and $\mathrm{LiBr}$ injection. \\
\hline & 1200 & End of instantaneous streamflow measurements along reach. \\
\hline & 1630 & End of bromide sampling at furthest downstream transport site in reach $(\mathrm{PC} 5,280)$. \\
\hline
\end{tabular}

reasons. The lower two-thirds of the study area (secondary study reach) was investigated by using conventional current-meter techniques and synoptic water-quality sampling. Several instantaneous streamflow measurements were made at selected sites as a quality-control measure. These data provided a measure of the stability of the streamflow over the several days of field activities and during the actual synoptic sampling. These data also provided a measure of the reasonableness of the streamflow estimates using tracer-dilution techniques. Synoptic sampling along the primary and secondary reaches was done on three separate days. In each case, synoptic sampling was scheduled to be done as early in the day as possible to avoid potential input from melting ice along the banks of Piceance Creek. Sampling was done in an upstream order to avoid potential contamination. 


\section{Tracer Injection}

A reconnaissance of the study area in September 2000 indicated that two tracer injections were needed along the primary study reach because of the length of the reach, the low streamflow velocity, and the presence of a small irrigation impoundment between PC5,280 and PC6,625. Bromide was chosen as the tracer because of the low concentrations in samples collected during the reconnaissance (James W. Ball, USGS, written commun., 2000). The median bromide concentration was 0.09 milligram per liter in 25 background samples collected. The first injection began at 0800 on December 4, 2000, at PC6,625 and was continuous for 28 hours (table 2). A concentrated solution of sodium bromide $(\mathrm{NaBr})$ was injected using a positive-displacement metering pump system. The stream reach extended from just downstream from PC6,625 to PC11,483 (fig. 2). Four samples of the injectate were collected periodically to confirm steady-state injection parameters. The samples were subsequently analyzed by the USGS National Research Program in Boulder, Colorado, to determine injection rates and bromide concentrations (James W. Ball, USGS, written commun., 2001). The injection rate varied by less than 3 percent and ranged from 325 to 335 milliliters per minute (fig. 4); the average rate of 332 milliliters per minute was used to calculate streamflow. The bromide concentration ranged from 176.4 to 177.2 grams per liter (fig. 4); the average concentration of 176.7 grams per liter was used to calculate streamflow.

The second injection began at 0800 on December 6, 2000, and continued for 27 hours (table 2). A concentrated solution of lithium bromide $(\mathrm{LiBr})$ was injected along the stream reach from just downstream from the Ryan Gulch streamflow-gaging station (PC0) to PC5,280 (fig. 2). Seven injectate samples were collected and subsequently analyzed to determine injection rates and bromide concentrations (James W. Ball, USGS, written commun., 2001). The variability in the bromide concentrations for this injection was larger than expected. Concentrations in three samples collected the day before the synoptic sampling were statistically different from the four collected the day of sampling (James W. Ball, USGS, written commun., 2001). As such, only the samples collected on the day of the synoptic sampling were used to calculate streamflow. The injection rate for these four samples varied by 1 percent and ranged from 318.6 to 321.2 milliliters per minute (fig. 4); the average rate of 320 milliliters per minute was used to calculate streamflow. The bromide concentration ranged from 165.1 to 173.5 grams per liter (fig. 4); the average concentration of 168.9 grams per liter was used to calculate streamflow.

Multiple bromide samples were collected at eight transport sites (table 1 and fig. 2) in Piceance Creek during the two tracer injections. Transport sites are sampling locations where numerous tracer samples are collected to determine if steady-state injection parameters have been established prior to synoptic sampling. Transport sites T5 to T8 were associated with the $\mathrm{NaBr}$ injection from PC6,625 to PC11,483 on December 4 and 5, 2000 (fig. 5). Transport sites T1 to $\mathrm{T} 4$ were associated with the $\mathrm{LiBr}$ injection from PC0 to PC5,280 on December 6 and 7, 2000 (fig. 6). Data collected at the transport sites are used to determine if tracer concentrations in the stream have reached a plateau concentration, which indicates that stable injection parameters have been attained. Also, the decrease in plateau concentrations at subsequent downstream transport sites can be used as a measure of the increase in streamflow at these locations (Kimball, 1997). Tracer samples collected at these sites generally are collected manually as the tracer arrives at each site. Thereafter, it is common to use automatic samplers programmed to collect samples at pre-determined times and/or intervals; automatic samplers provide the temporal coverage that cannot be easily maintained by manual sampling.

The automatic samplers were only marginally successful during the $\mathrm{NaBr}$ injection on December 4 and 5 because of cold temperatures in the study area. Intake lines became restricted with ice or froze entirely as water was pumped from the creek. Manual sampling procedures were implemented at 0730 on December 5 when it became apparent that the samplers had not functioned as anticipated (table 2). No plateau concentrations were calculated at T5, T6, $\mathrm{T} 7$, and $\mathrm{T} 8$ because of the limited number of samples and the concern that the samples might not accurately represent the bromide concentration in the creek (fig 5). It was assumed, however, that steady-state injection conditions were in effect and that the injection had proceeded long enough to reach plateau concentrations. Time of travel estimates using a fluorescent dye injection the previous day indicated that sufficient time had elapsed for the bromide tracer to come to a plateau in Piceance Creek. Therefore, 


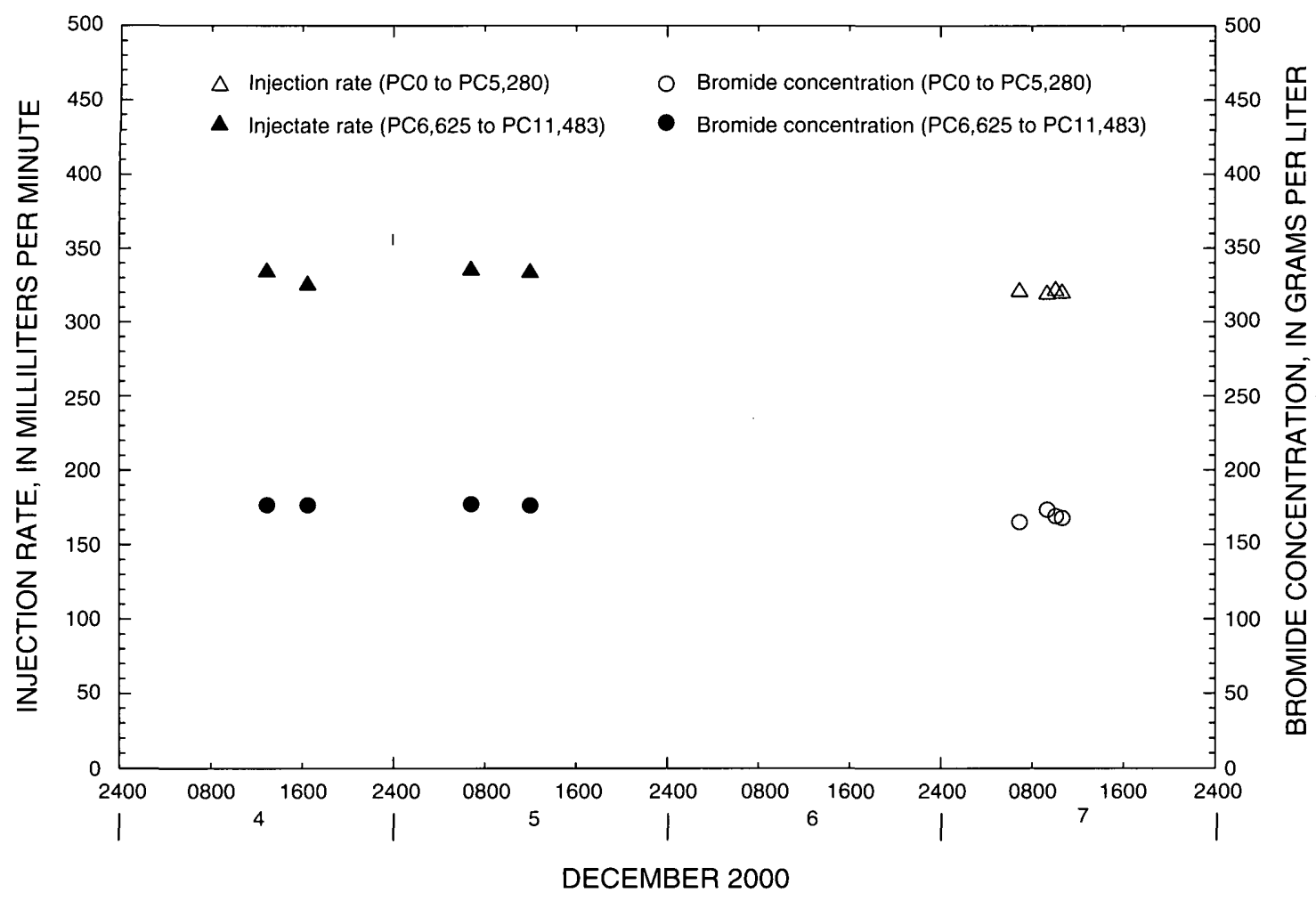

Figure 4. Injection rates and bromide concentrations from injectate samples collected during tracer-injection study in Piceance Creek, December 4 and 5, 2000, and December 7, 2000.

bromide samples collected manually at about the same time as the synoptic water-quality sample were used to represent plateau bromide concentrations at $\mathrm{T} 5, \mathrm{~T} 6$, $\mathrm{T} 7$, and $\mathrm{T} 8$.

The majority of $\mathrm{LiBr}$ samples collected December 6 and 7 were collected manually because of the limitations encountered earlier with the automatic samplers. However, the intake tubing to the automatic samplers was modified so at least one or two samples could be collected early on December 7 . These data points were important in determining if tracer concentrations in the stream had reached plateau concentrations. Sufficient data were collected to calculate plateau concentrations at $\mathrm{T} 1, \mathrm{~T} 2, \mathrm{~T} 3$, and $\mathrm{T} 4$ (fig. 6). The synoptic-bromide concentrations at T1, T3, and T4 compare favorably with the calculated bromide plateaus at each site, whereas, the synoptic concentration at $\mathrm{T} 2$ was somewhat higher than the plateau concentration. It appears that a change in pump parameters increased the bromide concentration in the steam. A more complete description of this event is forthcoming. Samples collected at the rise and fall of the bromide injection were not used to calculate plateau concentrations.

\section{Supplemental Instantaneous Streamflow Measurements}

Instantaneous streamflow measurements using standard techniques (Rantz and others, 1982) were made at selected sites along the primary and secondary study reaches. These data were used to determine if streamflow conditions remained constant throughout the study period, particularly during synoptic sampling. In addition, the measurements help determine the reasonableness of the tracer-dilution streamflow estimates. The data, however, were not intended as a check of the accuracy of the tracer-dilution streamflow estimates because standard techniques do not measure the flow in the hyporheic zone (Zellweger and others, 1988). In high-gradient mountain streams with rock and cobble streambeds, tracer-dilution techniques have been reported to account for about 30 percent more water than instantaneous streamflow measurements (Kimball and others, 1998). Overall, 

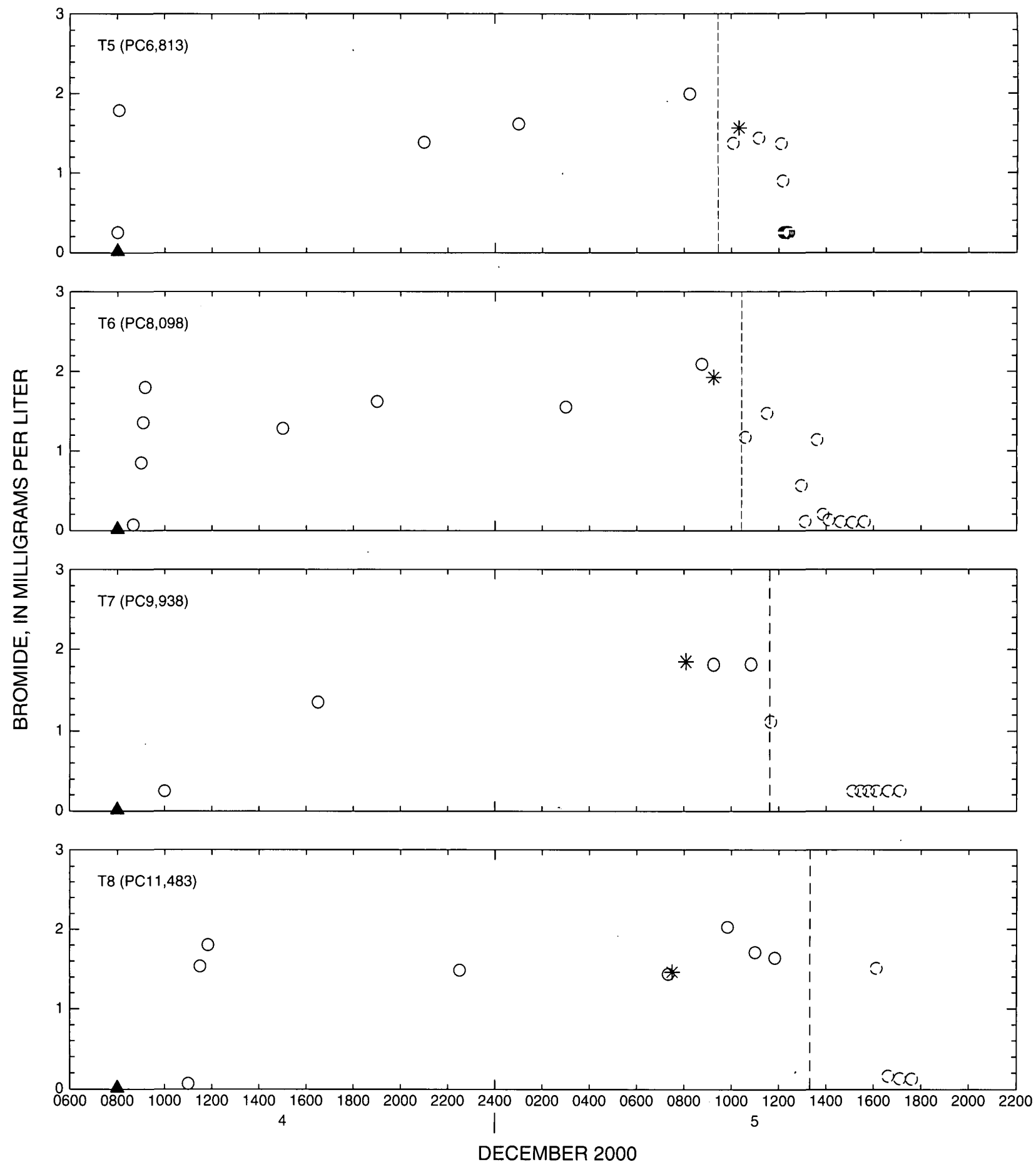

EXPLANATION

O TRANSPORT SAMPLE $\because$ TRANSPORT SAMPLE (SUSPECT) $\quad *$ SYNOPTIC SAMPLE $\quad \boldsymbol{\Delta}$ INJECTION START

Note: Vertical reference line represents the approximate time when increased streamflow affected injectate-bromide concentrations.

Traveltimes estimated from earlier dye injection efforts.

Figure 5. Bromide concentrations at transport sites T5 to T8 in Piceance Creek, December 4 and 5, 2000. 

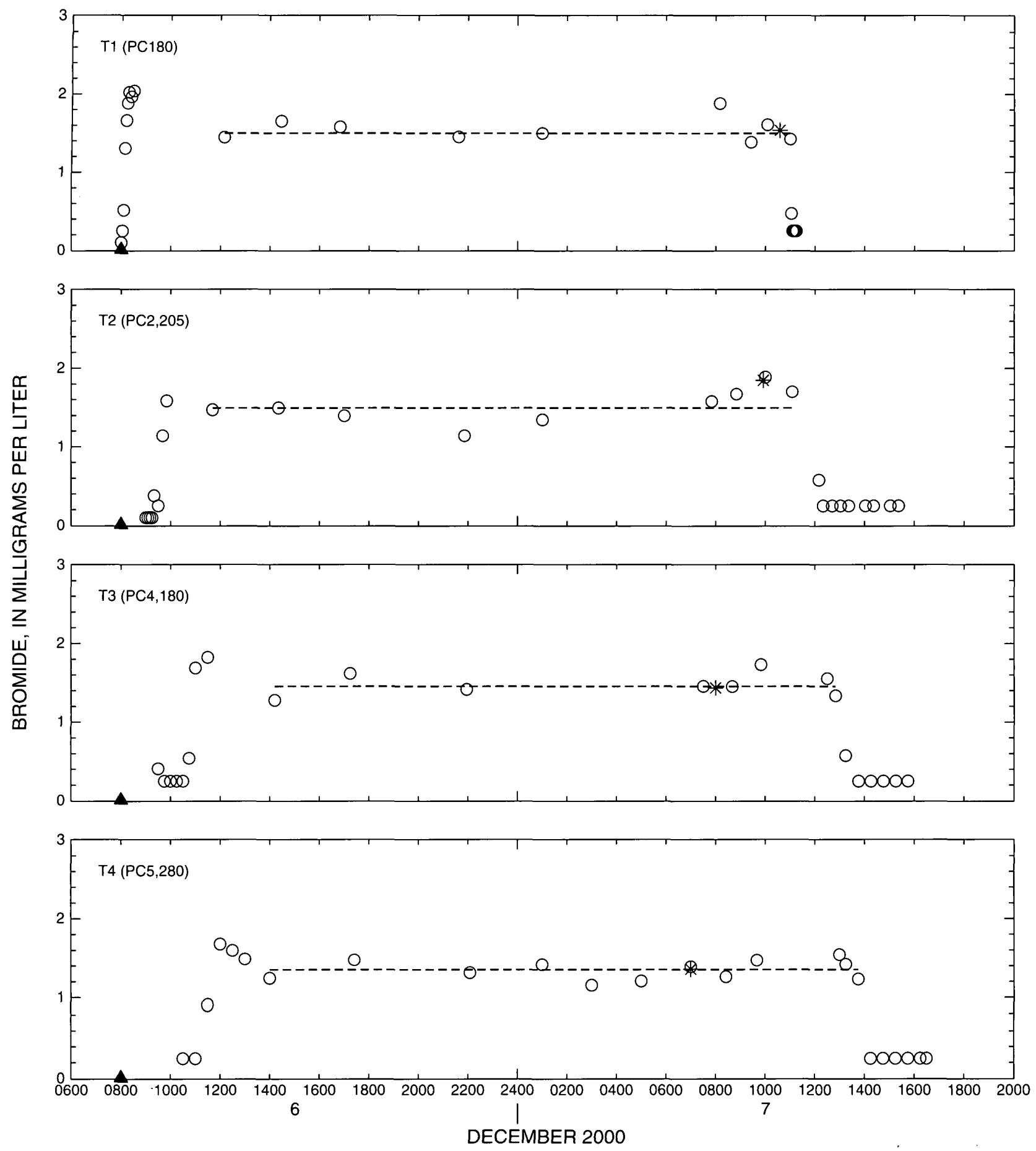

EXPLANATION

--- plateau O transport sample * synoptic sample $\quad$ InJection start

Figure 6. Bromide concentrations at transport sites T1 to T4 in Piceance Creek, December 6 and 7, 2000. 
the error associated with the instantaneous streamflow measurements made during this study was estimated to be about 15 percent.

Streamflow measurements made at PC0 (December 4 at 0740 and December 7 at 0800) and PC11,483 (December 3 at 0945 and December 5 at 1000) were used to determine if base-flow conditions remained constant during the study period (table 3). Instantaneous measurements were needed because the two streamflow-gaging stations in the study area were not operational at the time because of freezing temperatures. The relative percent difference (RPD) of the two sets of measurements was about 6 percent at PC0 and 9 percent at PC11,483. RPD is calculated by dividing the absolute value of the streamflow difference by the mean of the streamflow; the result is shown as a percentage. These data indicated that baseline streamflow conditions were relatively stable during the study period.

Streamflow measurements also were done to determine if streamflow conditions remained constant during synoptic water-quality sampling on December 5 and December 7, 2000. Measurements made on December 5 at PC6,625 (at 0900) and PC11,483 (at 1000) indicated that streamflow probably was stable at 0900 hours (table 3 ); synoptic sampling had proceeded in an upstream order to PC 8,448 by this time (table 1). However, less than 2 hours later, streamflow at PC6,625 had increased nearly twofold (960 liters/second; table 3 ) as water was released from the upstream impoundment. It appears that an ice dam across the outlet works of the impoundment gave way releasing a large amount of water. Analysis of specific conductance and $\mathrm{pH}$ data indicated that the water was native to the stream (table 1) and, as such, no change in chemical concentrations was expected. All synoptic samples collected downstream to PC 7,978 exhibited lower than expected bromide concentrations, which indicated that dilution of the injectate solution had occurred. The implications of the change in streamflow on the synoptic bromide concentrations and subsequent estimates of streamflow downstream will be discussed in a later section. On December 7, instantaneous measurements at PC0; PC2,205; and PC5,280 and gage-height measurements at $\mathrm{PC} 0$ indicated that streamflow was relatively stable throughout the synoptic sampling on that date (table 3 ).

\section{Synoptic Sampling}

Synoptic sampling provides a spatially detailed description of the water quality in a stream and is accomplished by sampling numerous sites in a relatively short time. In addition, synoptic samples provide both the tracer-concentration data needed to estimate streamflow and the concentration data needed to compute loads. Synoptic sampling along each subreach of Piceance Creek was conducted early in the morning and as quickly as possible to avoid changes in streamflow due to diurnal variation. Samples were collected in an upstream order near the centroid of the stream in clean, 4-liter plastic containers. The samples were transported to a centrally located staging area and processed as soon as possible. A list of the sites, sampling dates, and sampling times are in table 1. Field values of $\mathrm{pH}$ and specific conductance were determined on an unfiltered aliquot of each sample (table 1). The remaining sample volume was filtered through a 0.45 -millimeter capsule filter and preserved as described by Horowitz and others (1994). All synoptic samples were submitted for analysis to the USGS National Water Quality Laboratory (NWQL) in Lakewood, Colorado.

All synoptic water-quality samples were analyzed for a base list of constituents that was consistent with the standard list of analytes in the groundwater monitoring program for the Yankee Gulch Project (Agapito Associates, Inc., 1999). The analytes included dissolved major ions, selected trace constituents, alkalinity, and residue on evaporation. These constituents are possible indicators of fluid migration away from the production solution-mining zone (Douglas B. Yager, U.S. Geological Survey, written commun., 2000). In addition, samples collected at seven spatially dispersed sites (designated as indicator sites in table 1) were analyzed for additional dissolved constituents consistent with the USGS water-quality monitoring program at the Ryan Gulch (09306200) and White River (09306222) streamflow-gaging stations (Crowfoot and others, 2001) and the comprehensive list of parameters for the ground-water monitoring program at the Yankee Gulch site (Agapito Associates, Inc., 1999). This expanded list included additional trace constituents, dissolved organic carbon, nitrogen and phosphorus compounds, and gross alpha and beta radioactivity. Specific chemical data for all sites are listed in table 5 in the Data Section at the back of the report. 
Table 3. Summary of instantaneous streamflow measurements made along the primary study reach of Piceance Creek, December 3-7, 2000

[L/s, liters per second; --, no data; 09306200 denotes U.S. Geological Survey streamflow-gaging-station number]

\begin{tabular}{|c|c|c|c|c|c|}
\hline Site name & Date & Time & $\begin{array}{l}\text { Streamflow }{ }^{1} \\
\quad(L / s)\end{array}$ & $\begin{array}{c}\text { Outside } \\
\text { gage } \\
\text { height }^{2} \\
\text { (feet) }\end{array}$ & Remarks \\
\hline PC11,483 & $12-3-00$ & 0945 & 509 & -- & Prior to injection. Needed to determine injection parameters. \\
\hline $\mathrm{PCO}$ & $12-4-00$ & 0740 & 448 & -- & Prior to injection along reach. \\
\hline PC6,625 & $12-5-00$ & 0900 & 500 & -- & Above injection site. Sampling started at 0730 at PC1 1,483. \\
\hline $\mathrm{PC} 11,483$ & $12-5-00$ & 1000 & 466 & -- & $\begin{array}{l}\text { Downstream end of subreach. Soft bottom with ice throughout. Slow } \\
\text { velocities. Measurement likely underestimated streamflow. }\end{array}$ \\
\hline PC6,625 & $12-5-00$ & 1040 & 960 & -- & $\begin{array}{l}\text { Rise in stage noted. Abrupt change in streamflow due to release of water } \\
\text { from impoundment. Last synoptic sample collected at } 1040 \text { at PC6,625. }\end{array}$ \\
\hline PC8,098 & $12-5-00$ & 1120 & 952 & -- & Streamflow increased in response to release of water from impoundment. \\
\hline PC11,483 & $12-5-00$ & 1200 & 764 & -- & Streamflow increasing in response to release of water from impoundment. \\
\hline $\mathrm{PC} 0$ & $12-7-00$ & 0700 & -- & 3.58 & $\begin{array}{l}\text { At } 09306200 \text { (Ryan Gulch streamflow-gaging station). Outside gage height } \\
\text { only. Sampling started at } 0700 \text { at PC5,280. }\end{array}$ \\
\hline PC5,280 & $12-7-00$ & 0720 & 451 & -- & At downstream end of subreach. \\
\hline PC0 & $12-7-00$ & 0800 & 421 & 3.58 & At 09306200 . Approximately 20 percent shore ice. \\
\hline $\mathrm{PCO}$ & $12-7-00$ & 0840 & -- & 3.58 & At 09306200 . Outside gage height only. \\
\hline PC2,205 & $12-7-00$ & 0850 & 434 & -- & At Horse Draw bridge to mine site. \\
\hline $\mathrm{PC} 0$ & $12-7-00$ & 0915 & -- & 3.62 & At 09306200 . Outside gage height only. \\
\hline PC5,280 & $12-7-00$ & 0930 & 438 & -- & At downstream end of subreach. \\
\hline $\mathrm{PCO}$ & $12-7-00$ & 1010 & -- & 3.61 & At 09306200 . Outside gage height only. \\
\hline $\mathrm{PC} 0$ & $12-7-00$ & 1100 & -- & 3.58 & $\begin{array}{l}\text { At } 09306200 \text {. Outside gage height only. Last synoptic sample collected } \\
\text { at } 1040 \text { at } 09306200 .\end{array}$ \\
\hline PC6,625 & $12-7-00$ & 1130 & 730 & -- & Measurement made after last synoptic sampling along upper reach. \\
\hline
\end{tabular}

\footnotetext{
${ }^{1}$ Measurements were rated as fair to poor with an estimated error of 15 percent.
}

${ }^{2}$ Reading taken from wire weight with an estimated error of plus or minus 0.02 foot.

\section{Quality Assurance}

Data-collection and analytical procedures used in this study incorporated practices designed to control, verify, and assess the quality of the sample data. Methods and associated quality control for collection and field processing of water-quality samples are described by Ward and Harr (1990), Horowitz and others (1994), and Wilde and others (1998). The quality of analytical results for waterquality samples can be evaluated with data from quality-control samples submitted from the field and analyzed concurrently in the laboratory with routine samples. In addition, internal quality-assurance practices at the NWQL were performed systematically to provide quality control of the analytical procedures (Pritt and Raese, 1995).

Four duplicate samples were collected to provide quantitative information on the precision and bias of the overall field and laboratory process. Selected analytical results for the field duplicates are presented in table 6 in the Data Section at the back of the report. The RPD among the duplicate concentrations generally was less than 10 percent, which indicates acceptable precision for analytical results.

Two field blanks were analyzed to identify the presence and magnitude of contamination that potentially could bias analytical results. Certified deionized water was used to produce a field blank that was subjected to the same processing and analysis as 
an environmental sample. Analytical results for field blanks are presented in table 7 in the Data Section at the back of the report. For the most part, the concentrations in the blanks were at or below the method reporting limits, which indicates that the synoptic. samples were free of significant or systematic bias from contamination. However, dissolved aluminum and zinc concentrations in the blank collected on December 7, 2000, were five to six times higher than the method reporting level. Further analysis determined that a systematic aluminum contamination had occurred in all synoptic samples collected that day. It is unclear if the contamination was associated the with field-processing procedures or the laboratory analysis. Nevertheless, the contamination was substantial enough to require removal of all aluminum data for samples collected on December 7, 2000. This was not the case with the elevated zinc concentration in the same blank sample. The contamination was not shown to be systematic in any other water-quality sample, and the data were retained.

\section{BASELINE CHARACTERIZATION OF WATER QUALITY}

Routine water-quality data have been collected at the Ryan Gulch (09306200; PC0) and White River (09306222; PC28,348) streamflow-gaging stations since 1970 (Crowfoot and others, 2001). Physical and chemical data collected from 1977 to 1981 for streams in the Piceance Creek Basin have been summarized (Tobin and others, 1985). A spatially comprehensive data-collection effort in Piceance Creek during steadyflow conditions in March 1981 indicated that major dissolved constituents in Piceance Creek generally increased in the downstream direction as ground water discharged to springs, streams, and valley-fill alluvial aquifers in various reaches of Piceance Creek (Tobin, 1987). The exact location and extent of hydrologic connections between aquifers and streams are not well known although bedrock and fracture-controlled springs are observed along Piceance Creek. A substantial change in water quality was observed as ground water discharged upward through an extensive northwest-southeast fracture zone that crosses Piceance Creek in the area known as Alkali Flat (Tobin, 1987) (fig. 2). Salts precipitated on the land surface by evaporation of the shallow ground water are visible during base-flow conditions. Data collected as part of this study provide (1) an updated characterization of the water quality in Piceance Creek between the two USGS streamflow-gaging stations and (2) a baseline characterization of the water quality in Piceance Creek before full-scale nahcolite solution mining begins at the Yankee Gulch Project.

\section{Physical Properties}

In December 2000, pH values in Piceance Creek were stable throughout the study reach (fig. 7). The $\mathrm{pH}$ values ranged from 7.9 to 8.1 (table 1) with a median value of 8.0 standard units. Specific conductance increased steadily along the upper two-thirds of the study reach to $\mathrm{PC} 17,860$ at a rate of about 10 microsiemens per centimeter per kilometer (fig. 7). Along the reach that included the Alkali Flat area (PC20,708 to PC23,721), the rate increased to nearly 1,000 microsiemens per centimeter per kilometer, which equated to a 14-percent increase in less than 3,000 meters. Specific conductance at a spring contact in the area (site AFS) was measured at 12,700 microsiemens per centimeter (table 1). Specific conductance remained elevated downstream to PC28,348. Overall, specific conductance in Piceance Creek ranged from 1,540 to 1,980 microsiemens per centimeter. The profile for dissolved-solids concentrations was similar to that described for specific conductance (fig. 7). Specific conductance was shown to be a good predictor of dissolved solids in Piceance Creek including the stream reach downstream from Alkali Flat (table 4).

\section{Major-Ion Concentrations}

Tobin (1987) reported the principal dissolved constituents in water from Piceance Creek as bicarbonate, sulfate, and sodium. In December 2000, the principal dissolved constituents in the study area remained the same. The median bicarbonate concentration was 610 milligrams per liter (table 5). The median sulfate concentration was 420 milligrams per liter. The median sodium concentration was 170 milligrams per liter. Ground-water dissolution of evaporite minerals of nahcolite and halite (Green River Formation), and oxidation of pyrite and hydrogensulfide gas (Uinta Formation) are most likely sources 


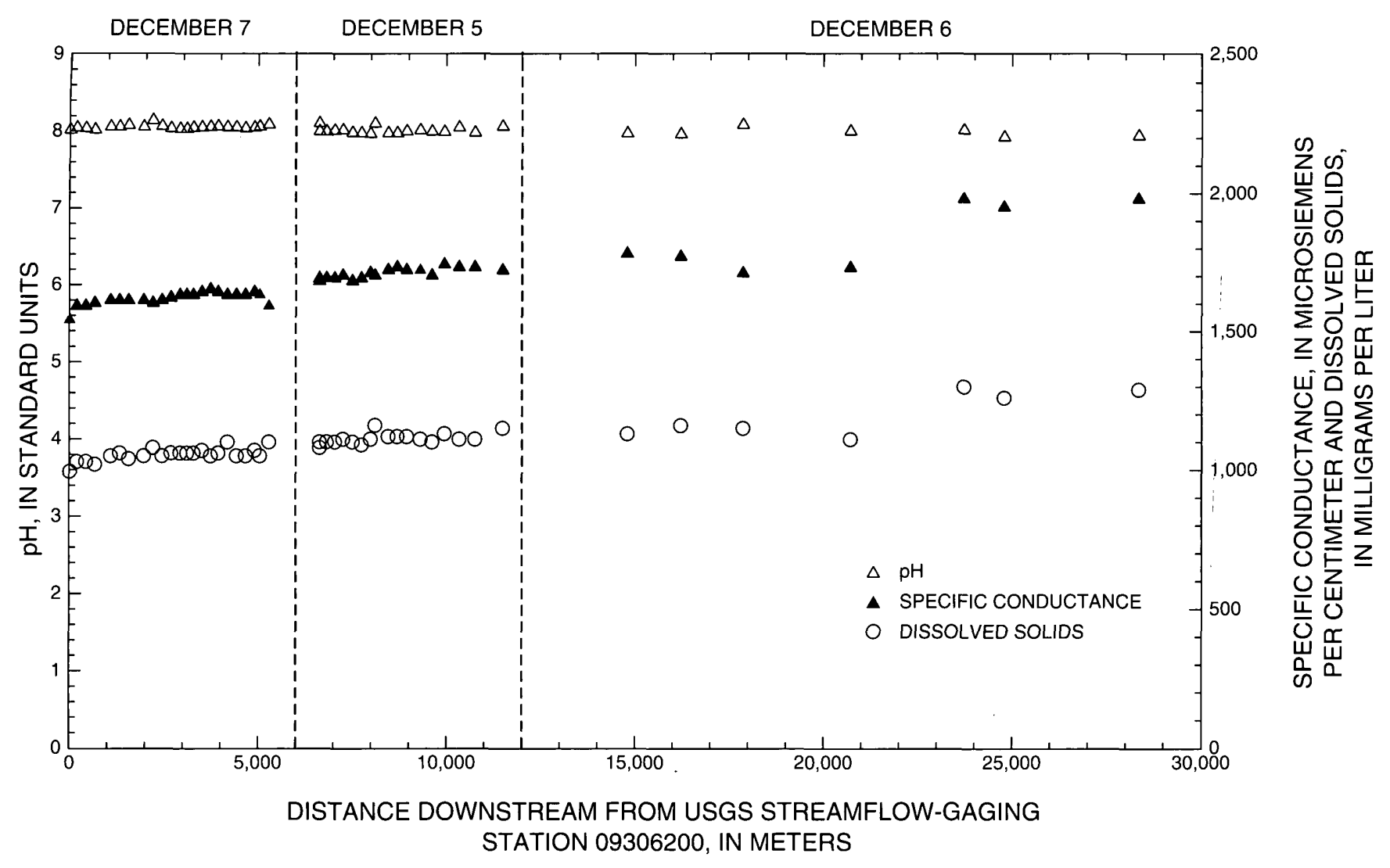

Figure 7. Values of $\mathrm{pH}$, specific conductance, and dissolved solids in Piceance Creek, December 5-7, 2000.

of these ions (George J. Saulnier, Jr., Duke Engineering, written commun., 2001).

Table 4. Linear regression statistics for predicting dissolved solids and selected ion concentrations in Piceance Creek from specific-conductance data, December 2000

\begin{tabular}{lccc}
\hline $\begin{array}{c}\text { Constituent } \\
\text { (in milligram per liter) }\end{array}$ & Slope & y intercept & $\mathbf{R}^{\mathbf{2}}$ \\
\hline Dissolved solids & 0.633 & 31.4 & 0.91 \\
Sodium & .298 & -319.0 & .96 \\
Bicarbonate & .693 & -530.8 & .85 \\
Chloride & .047 & -60.2 & .85 \\
\hline
\end{tabular}

Sodium, bicarbonate, and chloride concentrations increased gradually downstream from $\mathrm{PC} 0$ to PC20,708 as ground water discharged to the stream valley (table 5 and figs. 8 and 9). Overall, the increase along this 21-kilometer reach was from 25 to 35 percent; no sodium data were available from PC6,813 to PC11,483 because sodium bromide was used as the tracer along this reach. In contrast, a sharp increase in sodium ( 35 percent), bicarbonate (19 percent), and chloride ( 89 percent) concentrations was measured along a 3-kilometer reach between PC20,708 and PC23,721. This short reach of Piceance Creek flows across the area known as Alkali Flat (PC20,708 to PC23,721). Sulfate, calcium, magnesium, potassium, silica, and fluoride concentrations remained relatively constant throughout the study area including Alkali Flat. The relation of specific conductance to bicarbonate, sodium, and chloride concentrations in Piceance Creek is listed in table 4.

\section{Trace-Constituent Concentrations}

Characteristic trace constituents in the two major bedrock aquifers of the Piceance Creek Basin were identified as strontium in the Uinta Formation and barium, boron, and lithium in the Green River Formation (Tobin, 1987). Concentrations of barium, boron, lithium, and strontium also were elevated in 


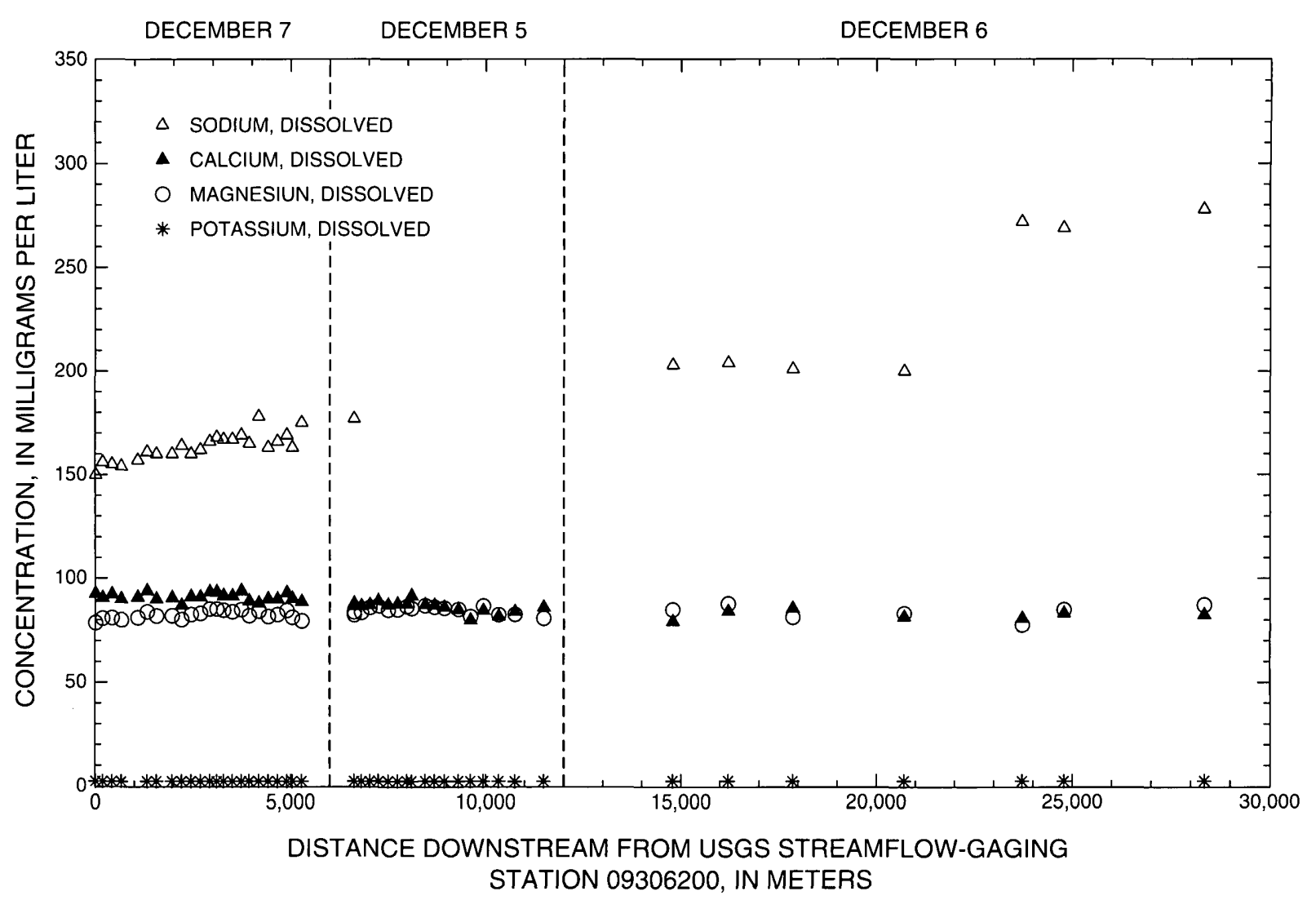

Figure 8. Selected dissolved-cation concentrations in Piceance Creek, December 5-7, 2000.

surface-water samples collected in Piceance Creek in December 2000 (table 5 and fig. 10). Strontium concentrations ranged from 2,810 to 3,390 micrograms per liter and were the highest of the trace constituents. However, concentrations remained relatively stable (median value about 2,990 micrograms per liter) throughout Piceance Creek including the reach along Alkali Flat. Barium concentrations (median value 75 micrograms per liter) and boron concentrations (median value 180 micrograms per liter) increased by about 50 to 65 percent from upstream to downstream. The largest increase in barium and boron concentrations occurred in the area of Alkali Flat. Although lithium was not analyzed for at all sites, a 70-percent increase in concentration was measured between PC17,860 and PC23,721. This reach includes the Alkali Flat area. Most other traceconstituent concentrations were at or near method reporting limits and little or no downstream increases were measured (table 5 and fig. 10).

\section{TRACER-INJECTION RESULTS}

Tracer-injection methods are used to determine streamflow at numerous sites in a relatively short time. This determination is accomplished by continuously injecting a known mass of a conservative tracer into the stream and measuring the concentration of the tracer at each downstream location. Using the principle of conservation of mass, a decrease in tracer concentration downstream (dilution) is a measure of an increase in streamflow. Variations in streamflow, injection flux (mass per unit time), and analytical precision can affect the measured tracer concentration at each site. An understanding of these variables is needed when interpreting the bromide profiles generated as part of these tracer injections. This understanding is particularly important in a stream such as Piceance Creek where downstream increases in streamflow were relatively small. 


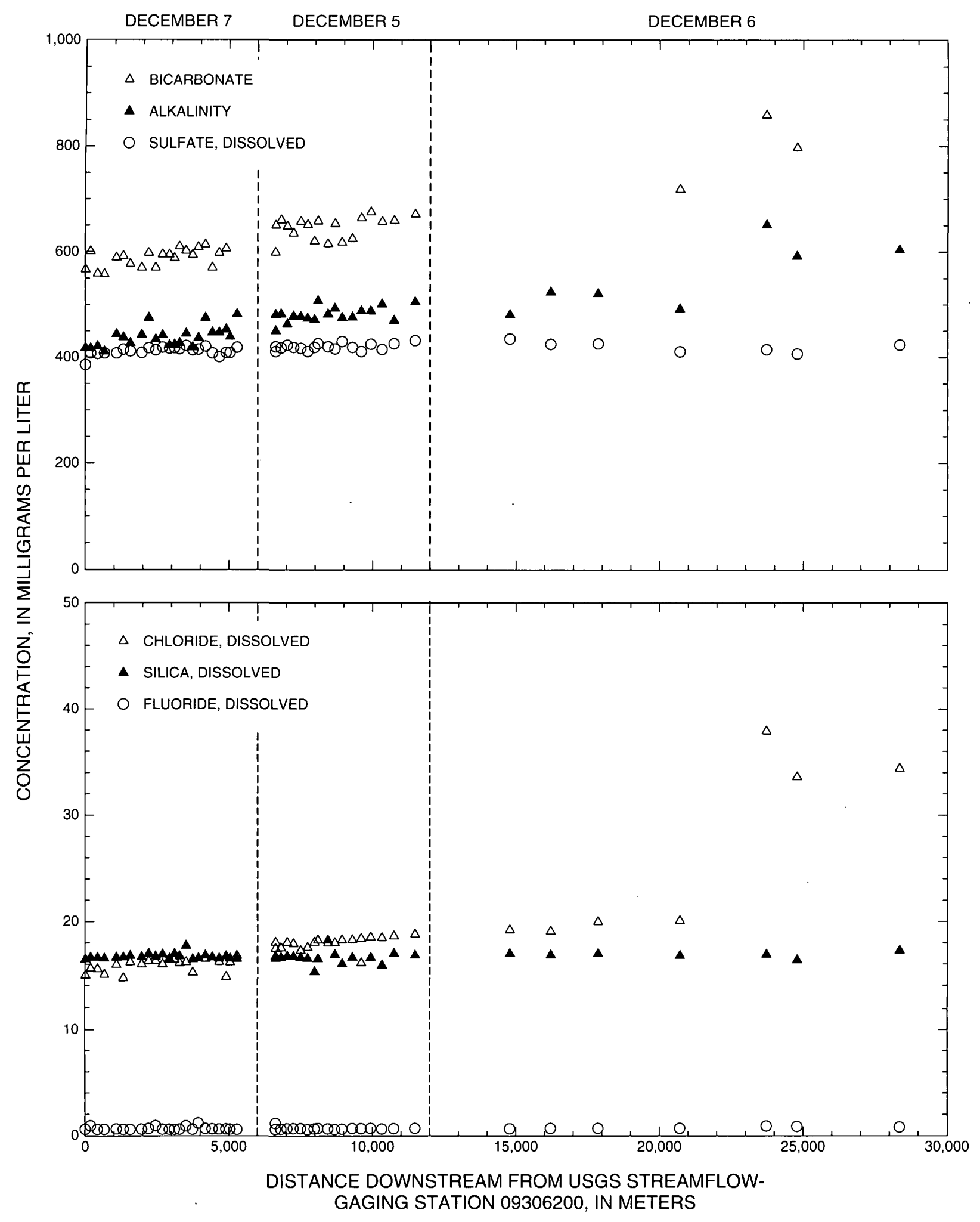

Figure 9. Selected dissolved-anion concentrations in Piceance Creek, December 5-7, 2000. 

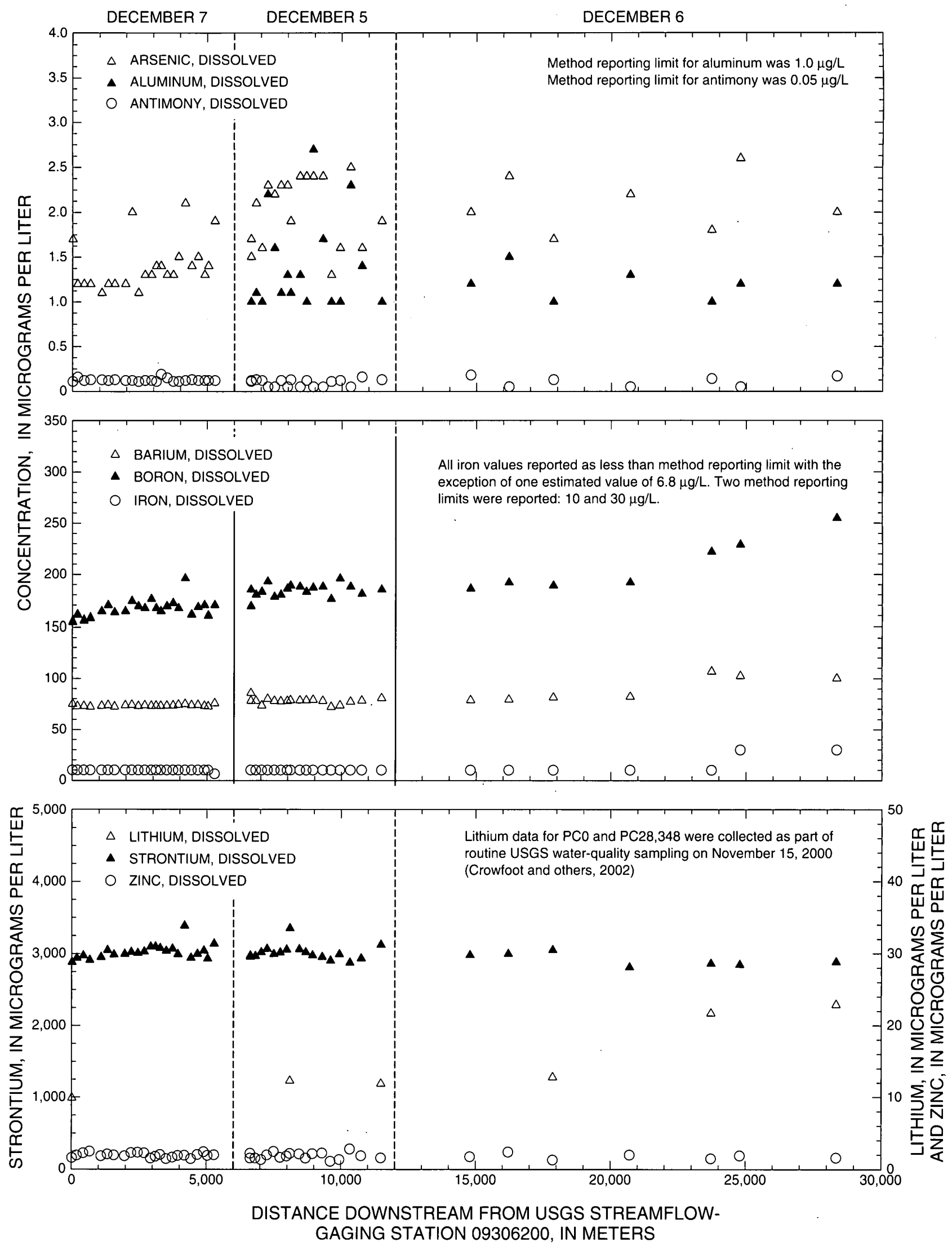

Figure 10. Selected dissolved-trace-constituent concentrations in Piceance Creek, December 5-7, 2000. 


\section{Synoptic Bromide Concentrations}

The first synoptic sampling event began at 0730 on December 5, 2000, along the primary study reach from PC6,625 to PC11,483 (fig. 2). Injectate-bromide concentrations in Piceance Creek were assumed to be at plateau concentrations because nearly 24 hours had elapsed since the start of the $\mathrm{NaBr}$ injection. Sampling began at the downstream site and proceeded upstream under stable streamflow conditions. However, a rapid increase in streamflow part way through the sampling diluted the synoptic-bromide concentrations in the stream upstream from PC8,098 (fig. 5); samples collected downstream from PC8,098 were unaffected by the increase because the samples had already been collected. As a result, synoptic bromide concentrations upstream from PC8,098 did not represent steady-state streamflow conditions (fig. 11). For the purpose of defining a bromide profile along the affected reach, the last bromide concentration collected at PC6,813 as part of the transport data (at 0815 hours) was substituted for the suspect synoptic concentration at this site (fig. 5). Intermediate bromide concentrations were estimated using a linear interpolation between PC6,813 and PC8,098. Bromide concentrations generally decreased downstream from PC8,098 along the reach unaffected by the sudden increase in streamflow. A smoothed line was drawn for these remaining bromide concentrations. The bromide concentrations from the smoothed line were used to develop an estimated streamflow profile for this reach. An error of plus or minus 3 percent was assumed for all bromide determinations.

The second synoptic sampling began at 0730 on December 7, 2000, along the upper section of the primary study reach from PC0 to PC5,280 (fig. 2). Synoptic sampling was done in an upstream order nearly 24 hours after the start of the LiBr injection. Supplemental streamflow measurements and stage data indicated that the streamflow was stable during the sampling (table 3). Synoptic bromide concentrations at PC180 (T1), PC4,180 (T3), and PC5,280 (T4) compared well with plateau bromide concentrations (fig. 6), which indicates that the synoptic concentrations were representative of stable injection conditions. However, the synoptic bromide concentration at PC2,205 (T2) was higher than the plateau concentration at this transport site (fig. 6). Analysis of injectate bromide samples collected at 0655 (882 milligrams per second) and 0920 (922 milligrams per second) indicated that a 4.5-percent increase in bromide flux to the stream occurred during this 2.5 -hour period.

Traveltimes from the injection site to PC2,205 (T2) support the hypothesis that elevated synoptic bromide concentrations observed between PC660 and PC4,180 were the result of increased bromide flux to the stream. For the purpose of defining a bromide profile for this reach, the plateau bromide concentration at PC2,205 (T2) was used in place of the synoptic bromide concentration. A linear interpolation then was used between PC2,205 and PC660 and between PC2,205 and PC4,180 to define intermediate concentrations (fig. 12). Synoptic-bromide concentrations generally decreased downstream from PC4,180.

A smoothed line was drawn between PC4,180 and PC5,280 (fig. 12). The bromide concentrations from the smoothed line were used to develop an estimated streamflow profile for the entire reach. An error of plus or minus 3 percent was assumed for all bromide determinations.

\section{Estimation of Streamflow}

Streamflow can be calculated at any site downstream from the tracer-injection site by using the concentration of the tracer in the stream, the background tracer concentration, the concentration of the injection solution, and the rate of injection. Streamflow profiles for each of the subreaches along the primary study reach of Piceance Creek (figs. 11 and 12) were developed by using the following equation (modified from Ortiz and Bencala, 2001):

$$
\mathrm{Q}=\mathrm{Q}_{\mathrm{INJ}} \mathrm{C}_{\mathrm{INJ}} /\left(\mathrm{C}-\mathrm{C}_{\mathrm{p}}\right)
$$

$$
\begin{gathered}
\text { where } \\
\mathrm{Q} \quad \begin{array}{l}
\text { is streamflow, in liters per second; } \\
\mathrm{Q}_{\mathrm{INJ}}
\end{array} \\
\begin{array}{c}
\text { is the rate of the tracer injection into the } \\
\text { stream, in liters per second; }
\end{array} \\
\mathrm{C}_{\mathrm{INJ}} \quad \begin{array}{c}
\text { is the tracer concentration in the injection } \\
\text { solution, in milligrams per liter; }
\end{array} \\
\mathrm{C} \quad \text { is the tracer concentration from the smoothed } \\
\text { tracer profile, in milligrams per } \\
\text { liter; and } \\
\mathrm{C}_{\mathrm{P}} \quad \text { is the tracer concentration in the background } \\
\text { sample, in milligrams per liter. }
\end{gathered}
$$

The instream tracer concentration was determined at each synoptic sampling site from a smoothed 

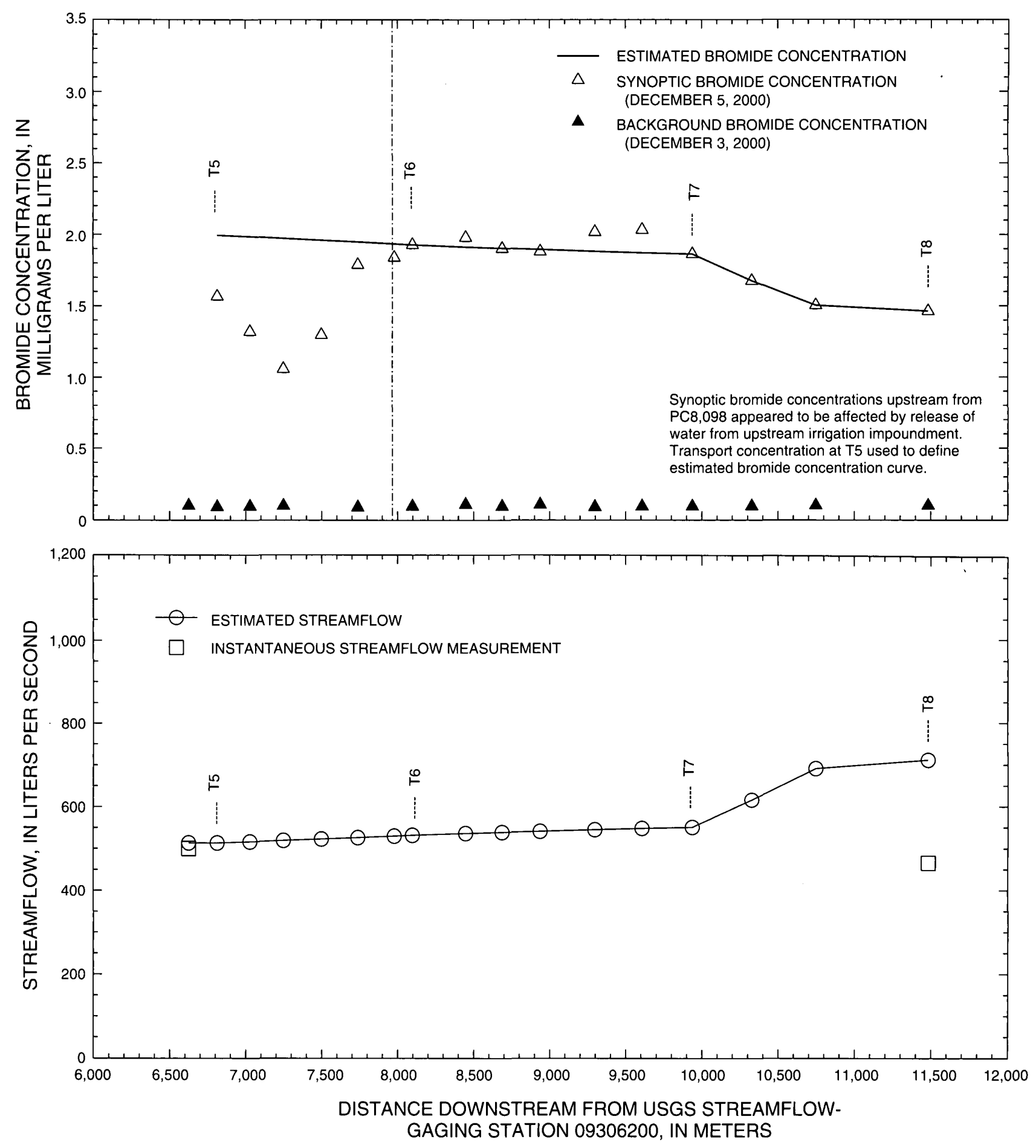

Figure 11. Bromide concentrations and estimated streamflow at synoptic sampling sites in Piceance Creek, December 5, 2000. 

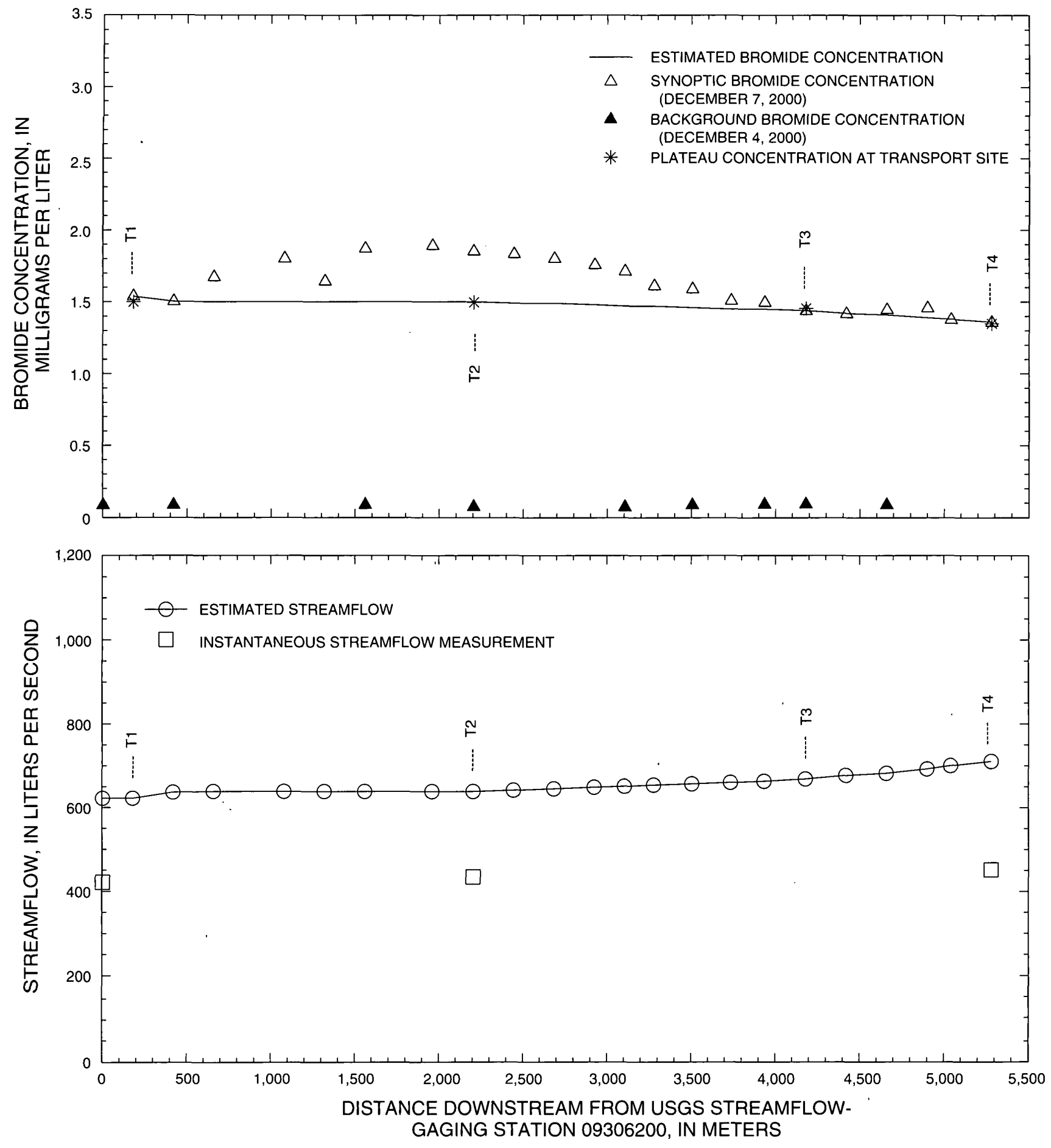

Figure 12: Bromide concentrations and estimated streamflow at synoptic sampling sites in Piceance Creek, December 7, 2000. 
profile of bromide concentrations (figs. 11 and 12). The median background bromide concentration was 0.09 milligram per liter in 25 stream samples collected prior to the injection. The average bromide concentration in the $\mathrm{NaBr}$ injection solution was 176,700 milligrams per liter; the average injection rate was 0.00553 liter per second. The average bromide concentration in the $\mathrm{LiBr}$ injection solution was 168,900 milligrams per liter; the average injection rate was 0.00533 liter per second. Analytical uncertainty associated with these determinations was estimated at plus or minus 2 percent for the $\mathrm{NaBr}$ injection and 4 percent for the $\mathrm{LiBr}$ injection (James W. Ball, U.S. Geological Survey, written commun., 2000).

The profiles show the increase in estimated streamflow along specific reaches of Piceance Creek. Streamflow increased by 14 percent or about 16 liters per second per 1,000 meters along the reach from PC0 to PC5,280 (fig. 12). A similar increase (12 liters per second per 1,000 meters) was measured between
PC6,625 and PC9,938 (fig. 11). Even though the same general streamflow pattern appears to exist along the entire reach from PC0 to PC9,939, the streamflow data derived from the two tracer injections should not be compared directly. Differences in sampling dates, injections solutions, injection parameters, and anomalies specific to each stream reach do not warrant the direct comparison of the streamflow estimates between the two reaches. Streamflow increased by 25 percent downstream from PC9,938 as the valley floor narrowed and, presumably, ground-water inputs increased (fig. 2).

In addition, seven instantaneous streamflow measurements were done in the secondary study reach in conjunction with synoptic sampling on December 6, 2000 (fig. 13). Streamflow generally increased downstream to PC17,860 and PC20,708. A substantial decrease in streamflow occurred between PC20,708 and PC23,721 along the Alkali Flat area; the area is known to be a region of extensive fracturing. Stream-

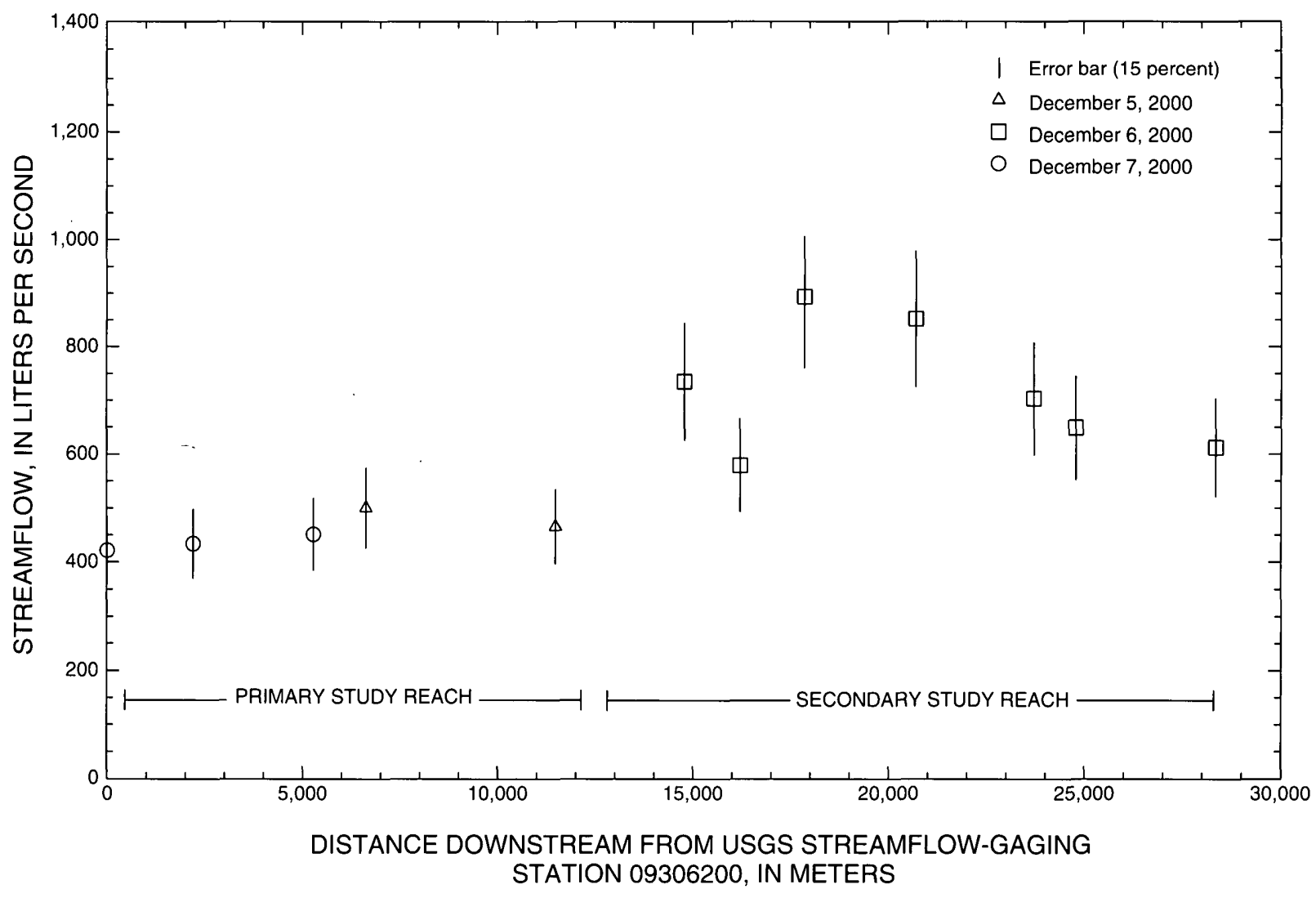

Figure 13. Instantaneous streamflow measurements along the primary and secondary study reaches in Piceance Creek, December 5-7, 2000. 
flow profiles presented by Tobin (1987) show a similar decrease in streamflow near this reach, but additional streamflow data are needed to better quantify these findings. These streamflow data were used to calculate loads along this lower reach of the study area. Instantaneous streamflow data along the secondary study reach should not be compared directly with streamflow estimates derived from the tracer injections (figs. 11 and 12) because tracer-dilution techniques can account for about 30 percent more water (Kimball and others, 1998).

\section{MASS LOADS}

Downstream load profiles can be used to illustrate graphically the spatial distribution of mass loads at many locations along a main stem and can be used to identify sources and sinks that affect the constituent load. The downstream mass load profiles for this study represent the instantaneous loads at each main-stem sampling site for each of the two tracer-injection reaches in the primary study reach and along the secondary study reach. The three stream reaches are presented separately because, as stated previously, streamflow profiles used to compute loads were not continuous between study reaches. No significant load input to Piceance Creek was detected along the primary study reach. Although substantial increases in constituent concentration were observed near Alkali Flat, apparent losses in streamflow along the secondary study reach resulted in relatively small increases in load downstream to the end of the study reach.

\section{Major lons}

Load profiles for dissolved cations (fig. 14) and anions (fig. 15) from PC0 to PC11,483 were similar to streamflow profiles in Piceance Creek for these same reaches (figs. 11 and 12). Overall, the loads increased gradually along the primary study reach, and the only substantial increase in load occurred between PC 9,938 and PC10,748. Increased loading along this short reach was more closely related to increased streamflow than to any large increase in concentration.
Presumably, ground-water inputs to the stream increased as the alluvial cross section constricted in the narrow valley.

Along the secondary study reach, the large increases in ion concentration that were observed in December 2000 (figs. 8 and 9) were offset by decreased streamflow along much of the reach (fig. 13). The resulting load profiles for most dissolved cations and anions downstream from PC 11,483 showed little or no increase (figs. 14 and 15). The only constituent load that increased appreciably along this reach was chloride, which increased nearly 50 percent. Additional investigation along the secondary study reach is needed to substantiate these findings.

\section{Trace Constituents}

Selected dissolved metal loading (fig. 16) from PC0 to PC11,483 also was similar to streamflow profiles in Piceance Creek for these same reaches (figs. 11 and 12). Overall, the loads increased gradually along the primary study reach and the only substantial increase in load occurred between PC9,938 and PC10,748 where, presumably, ground-water inputs to the stream increased as the alluvial valley narrowed. Barium, boron, and strontium loads were the only trace constituents readily quantifiable in the study area and, as such, are the only ones shown in figure 16. Most of the other concentrations were reported as near or below the method reporting levels.

Along the secondary study reach, load profiles for dissolved-trace constituents downstream from PC11,483 showed little or no increase (fig. 16). Because strontium concentrations (fig. 10) were unchanged throughout the secondary study reach, the resulting load profile indicated a loss of strontium mass downstream to PC28,348. Strontium is generally associated with the ground water of the Uinta Formation so increased ground water from the Green River Formation could reduce the proportion of strontium in this area (George J. Saulnier, Jr., Duke Engineering, written commun., 2001). Additional investigation along the secondary reach is needed to substantiate these findings. 


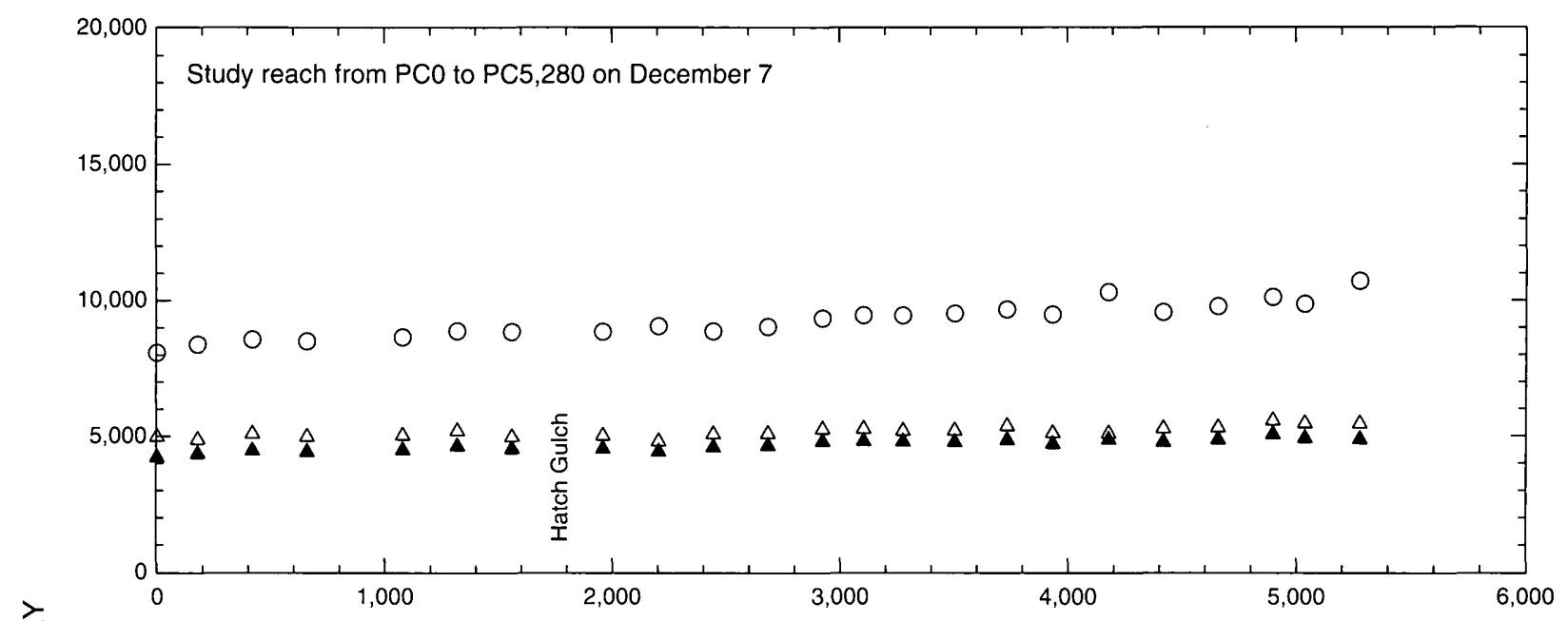

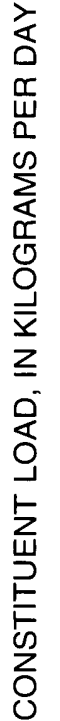
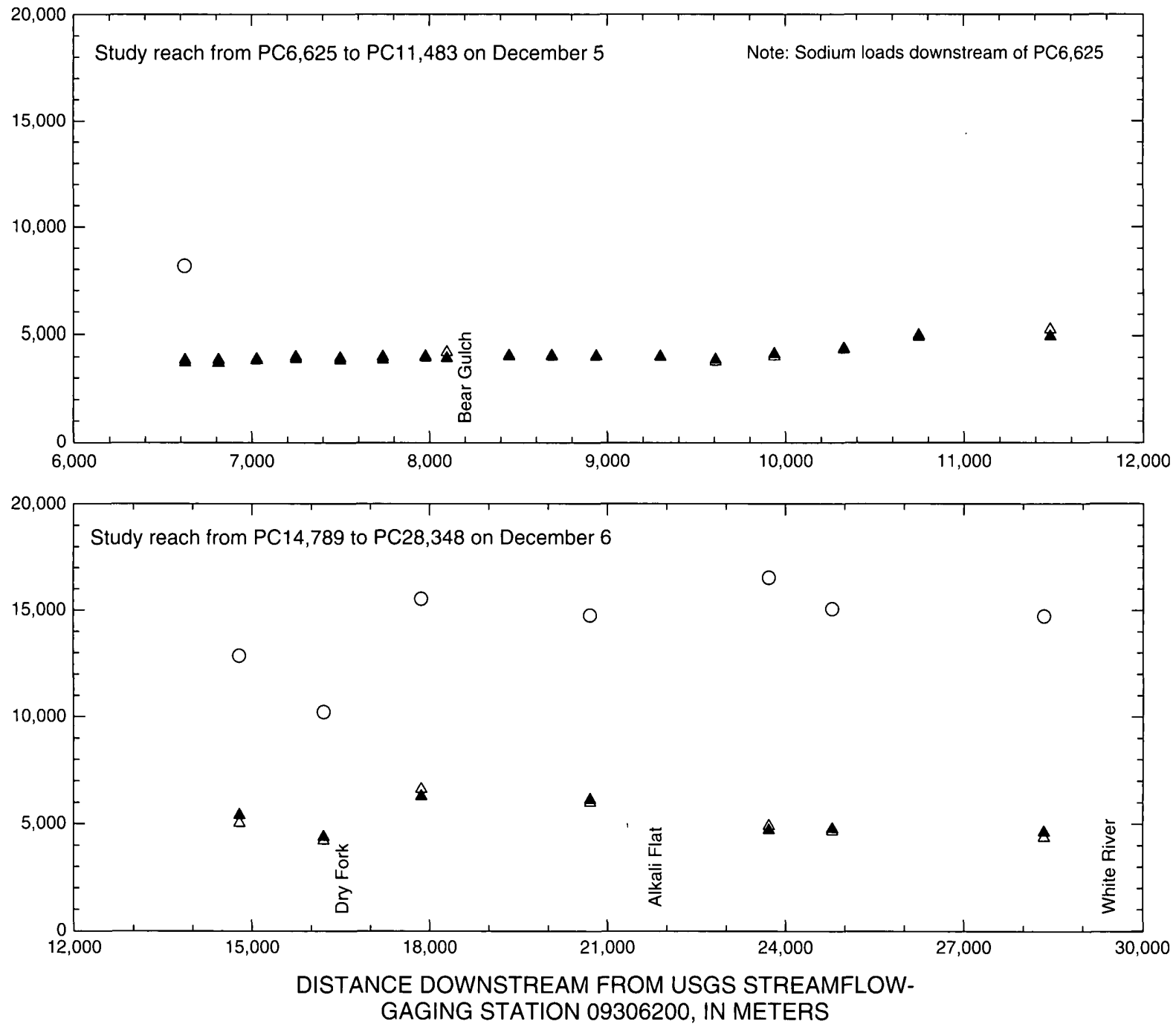

EXPLANATION

$\triangle$ DISSOLVED CALCIUM LOAD \ DISSOLVED MAGNESIUM LOAD O DISSOLVED SODIUM LOAD

Figure 14. Dissolved calcium, magnesium, and sodium loads in Piceance Creek, December 5-7, 2000. 


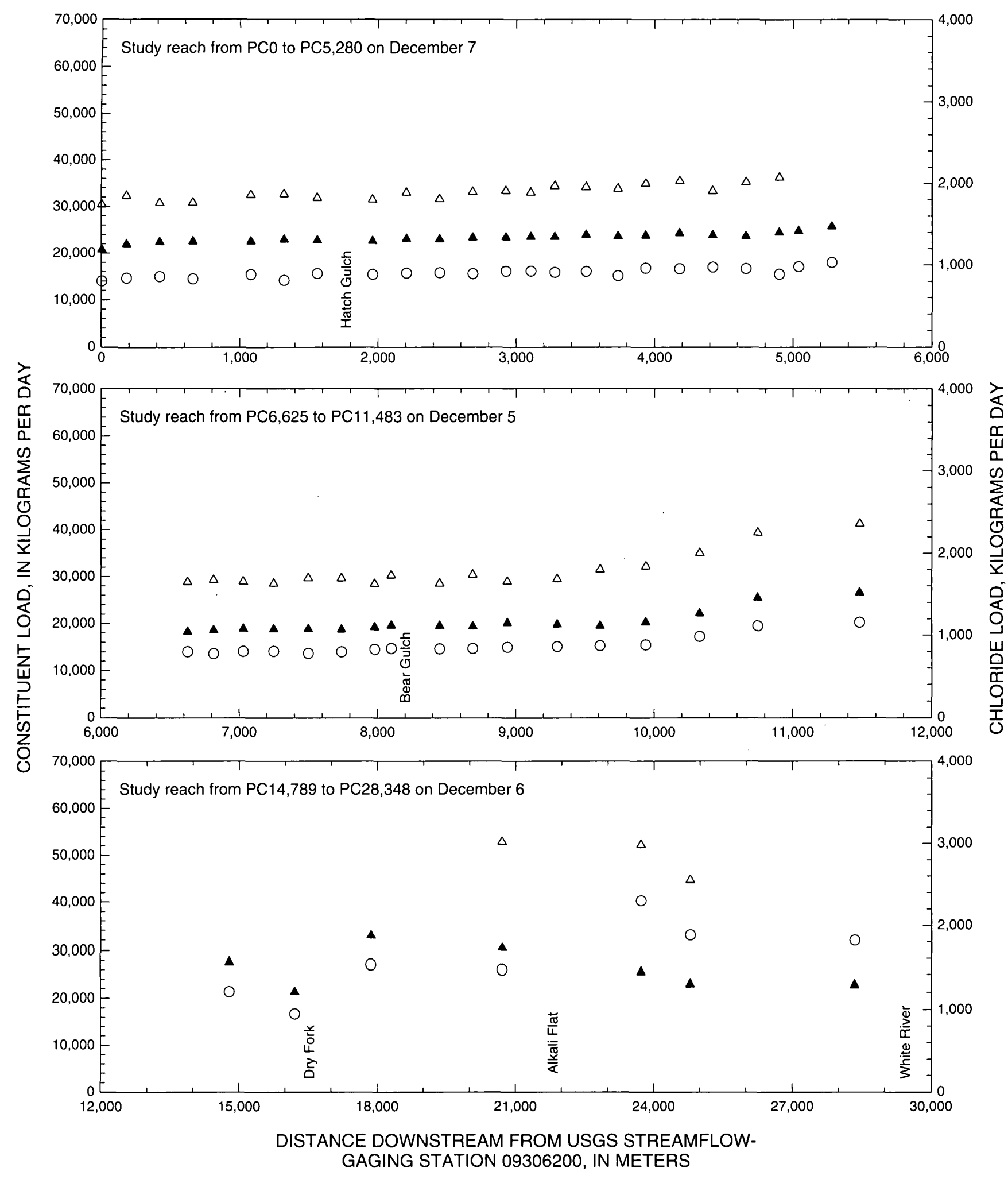

EXPLANATION

$\triangle$ DISSOLVED BICARBONATE LOAD \ DISSOLVED SULFATE LOAD O DISSOLVED CHLORIDE LOAD

Figure 15. Dissolved bicarbonate, sulfate, and chloride loads in Piceance Creek, December 5-7, 2000. 

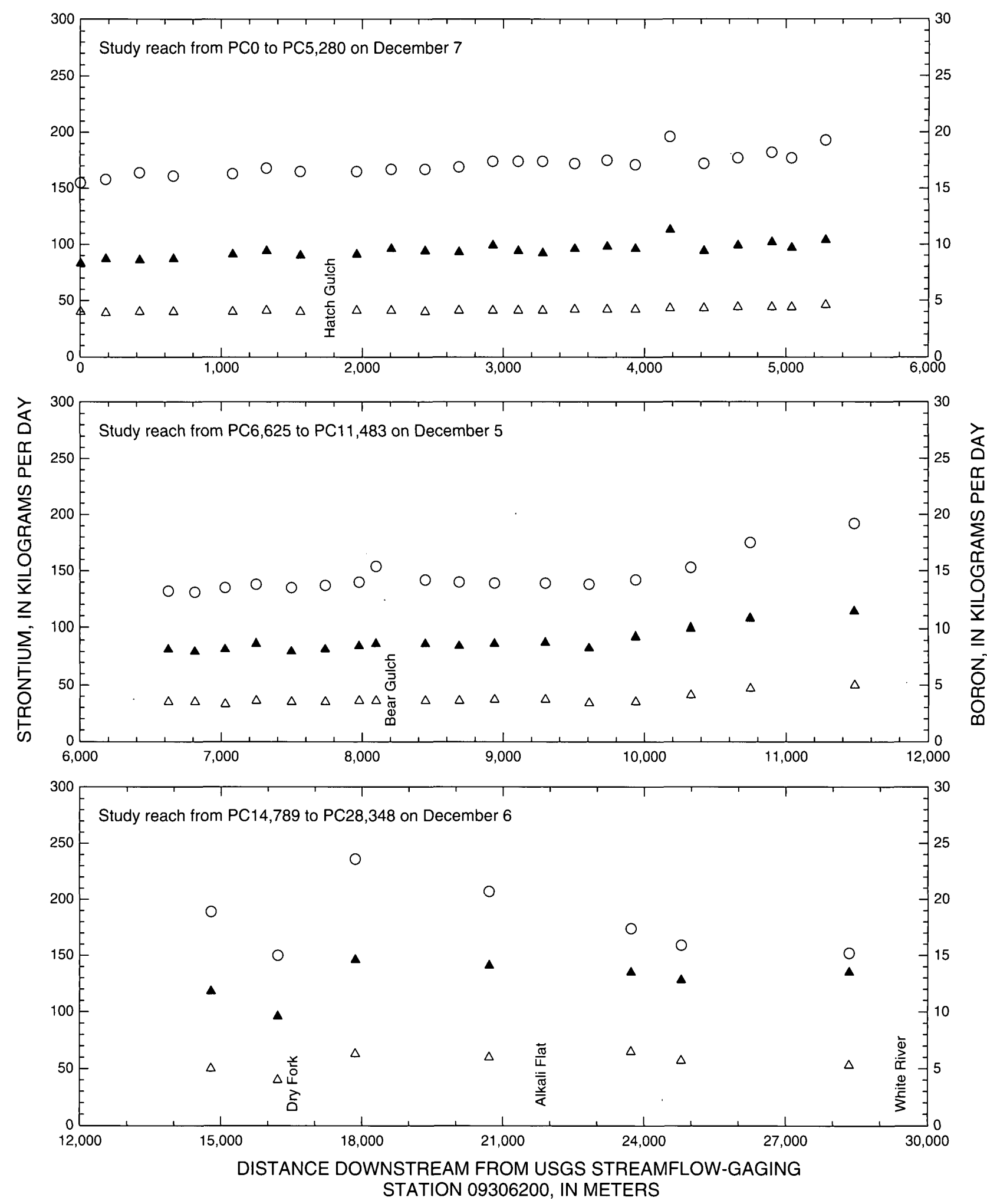

EXPLANATION

$\triangle$ DISSOLVED BARIUM LOAD \ DISSOLVED BORON LOAD O DISSOLVED STRONTIUM LOAD

Figure 16. Dissolved barium, boron, and strontium loads in Piceance Creek, December 5-7, 2000. 


\section{SUMMARY}

In recent years, the emphasis of resource development in the Piceance Basin has turned to commercial nahcolite solution mining for sodium bicarbonate (baking soda) and sodium carbonate (soda ash). The Yankee Gulch Sodium Minerals Project was required to submit a monitoring plan that, in part, would characterize the baseline water quality in the adjacent Piceance Creek. The U.S. Geological Survey (USGS) provided this characterization in cooperation with Rio Blanco County, Colorado. The purpose of this report is to provide a baseline characterization of the water quality in Piceance Creek and to quantify the mass load for selected chemical constituents in Piceance Creek during base-flow conditions. Physical and chemical data were collected during December 2000 at 47 main-stem sites and 4 inflow sites. The study area extended about 28 kilometers along Piceance Creek between the USGS streamflow-gaging stations 09306200 (PC0) and 09306222 (PC28,348). The primary study reach was along the approximately 11.5 kilometers of the study area adjacent to the lease boundary for the Yankee Gulch Sodium Minerals Project.

Tracer-dilution techniques and instantaneous measurements were used to determine streamflow in Piceance Creek. Synoptic-sampling techniques were used to determine baseline concentrations for selected constituents in Piceance Creek. Synoptic water-quality samples were analyzed for a base list of constituents that was consistent with the ground-water monitoring program for the mine. The constituents are possible indicators of fluid migration away from the solutionmining zone. Load profiles along subreaches of the creek were generated by combining tracer-dilution and synoptic-sampling techniques.

Data collected as part of this study provide an updated characterization of the water quality in Piceance Creek between the two USGS streamflowgaging stations 09306200 and 09306222 . In March 1981, a spatially comprehensive data-collection effort in Piceance Creek indicated increases in major dissolved constituents in the downstream direction as ground water discharged to springs, streams, and valley-fill alluvial aquifers. Additionally, a substantial change in water quality was observed as ground water discharged upward through an extensive northwestsoutheast trending fracture zone that crosses Piceance Creek in the area known as Alkali Flat.
In December 2000, $\mathrm{pH}$ values in Piceance Creek were stable throughout the study area and ranged from 7.9 to 8.1 standard units. Specific conductance increased steadily along the upper two-thirds of the study reach. The rate increased by nearly 14 percent along the reach that included Alkali Flat (PC20,708 to PC23,721). Specific conductance was shown to be a good predictor of dissolved solids in Piceance Creek. In 1987, bicarbonate, sulfate, and sodium were reported as the principal dissolved constituents in Piceance Creek. The principal dissolved constituents remained the same in December 2000. High concentrations of bicarbonate and sodium result from the contact of ground water with evaporite minerals nahcolite and halite in the Green River Formation. Sulfate is commonly high in the ground water of the overlying Uinta Formation. Sodium, bicarbonate, and chloride concentrations increased gradually ( 25 to 35 percent) downstream to $\mathrm{PC} 20,708$ as water discharged to the stream valley. A substantial increase in bicarbonate (19 percent), sodium (35 percent), and chloride (89 percent) occurred in the Alkali Flat area of Piceance Creek. Sulfate, calcium, magnesium, potassium, silica, and fluoride concentrations remained relatively constant throughout the study area. Concentrations of barium, boron, lithium, and strontium were elevated in Piceance Creek. Strontium concentrations were the highest but remained relatively constant throughout Piceance Creek. Barium and boron concentrations increased from 50 to 65 percent from upstream to downstream. The largest increase in barium and boron concentrations occurred in the area of Alkali Flat. Lithium also increased substantially between PC17,860 and PC23,721, which includes the Alkali Flat area. Concentrations of most of the other trace constituents were at or near method reporting limits, and little or no downstream increases were observed.

No significant load input to Piceance Creek was detected along the primary study reach. Although the area near Alkali Flat contributed substantially to the increase in constituent concentration in Piceance Creek, losses in streamflow along the secondary study reach resulted in relatively small increases in load downstream to the end of the study reach. Load profiles for dissolved cations, anions, and trace constituents from PC0 to PC11,483 were similar to streamflow profiles in Piceance Creek for this same reach. Overall, the loads increased gradually along the primary study reach, and the only substantial increase 
in load occurred between PC9,938 and PC10,748. Presumably, increased ground-water inputs to the stream resulted in a gradual increase in streamflow as the alluvial valley narrows. Along the secondary study reach, the increases in ion concentration that were observed were offset by decreased streamflow along much of the reach. The resulting load profiles for dissolved cations, anions, and trace constituents downstream from PC11,483 showed little or no increase. Additional investigation along the secondary study reach is needed to substantiate these findings.

\section{REFERENCES CITED}

Agapito Associates, Inc., 1999, Groundwater, surface water, and process monitoring plan for the Yankee Gulch Sodium Minerals Project: prepared for American Soda, LLP., Agapito Associates Inc., Grand Junction, Colorado, $30 \mathrm{p}$.

Beard, T.N., Tait, D.B., and Smith, J.W., 1974, Nahcolite and dawsonite resources in the Green River Formation, Piceance Creek Basin, Colorado: Rocky Mountain Association of Geologists 1974 Guidebook.

Colorado Climate Center, 2001, Daily temperature summary for Rifle, Colorado, for calendar year 2000: at URL http://ccc.atmos.colostate.edu

Crowfoot, R.M., Unruh, J.W., Boulger, R.W., and O'Neill, B.B., 2001, Water resources data for Colorado, Water Year 2000, v. 2, Colorado River Basin: U.S. Geological Survey Water-Data Report CO-00-2, 596 p.

___ 2002, Water resources data for Colorado, Water Year 2001, v. 2, Colorado River Basin: U.S. Geological Survey Water-Data Report CO-01-2, 596 p.

Dyni, J.R., 1987, Origin of the oil shale and associated minerals, in Taylor, J.O., ed., Oil shale, water resources, and valuable minerals of the Piceance Basin, Colorado: U.S. Geological Survey Professional Paper 1310, p. 17-20.

Donnell, J.R., 1987, Storehouse of energy minerals in the Piceance Basin, in Taylor, J.O., ed., Oil shale, water resources, and valuable minerals of the Piceance Basin, Colorado: U.S. Geological Survey Professional Paper 1310, p. 21-28.

Grout, M.A., and Verbeek, E.A., 1985, Fracture history of the Plateau Creek and adjacent Colorado River valleys, southern Piceance Basin-Implications for predicting joint patterns at depth: U.S. Geological Survey OpenFile Report 85-0744, 17 p.

Horowitz, A.J., Demas, C.R., Fitzgerald, K.K., Miller, T.L., and Rickert, D.A., 1994, U.S. Geological Survey protocol for the collection and processing of surfacewater samples for the subsequent determination of inorganic constituents in filtered water: U.S. Geological Survey Open-File Report 94-539, 57 p.

Kimball, B.A., 1997, Use of tracer injections and synoptic sampling to measure loadings from acid mine drainage: U.S. Geological Survey Fact Sheet 245-96, $4 \mathrm{p}$.

Kimball, B.A., Runkel, R.L., and Gerner, L.J., 1998, Quantification of metal loading in French Gulch, Summit County, Colorado, using a tracer-injection study, July 1996: U.S. Geological Survey Water-Resources Investigations Report 98-4078, 38 p.

Maclachlan, M.E., 1987, General geology of the Piceance Basin, in Taylor, J.O., ed., Oil shale, water resources, and valuable minerals of the Piceance Basin, Colorado: U.S. Geological Survey Professional Paper 1310, p. 7-17.

Norman, V.W., 1987, Suspended sediment in Piceance Creek, in Taylor, J.O., ed., Oil shale, water resources, and valuable minerals of the Piceance Basin, Colorado: U.S. Geological Survey Professional Paper 1310, p. $77-80$.

Ortiz, R.F., and Bencala, K.E., 2001, Determination of instream metal loads using tracer-injection and synoptic-sampling techniques in Wightman Fork, Southwestern Colorado, September 1997: U.S. Geological Survey Water-Resources Investigations Report 00-4154, 26 p.

Pritt, J.W., and Raese, J.W., eds., 1995, Quality assurance/quality control manual-National Water Quality Laboratory: U.S. Geological Survey Open-File Report 95-443, 35 p.

Rantz, S.E., and others, 1982, Measurement and computation of streamflow, Volume 1-Measurement of stage and discharge: U.S. Geological Survey Water-Supply Paper 2175, $284 \mathrm{p}$.

Robson, S.G., and Saulnier, Jr., G.J., 1981, Hydrogeochemistry and simulated solute transport, Piceance Basin, Northwest Colorado: U.S. Geological Survey Professional Paper 1196, 65 p.

Saulnier, Jr., G.J., and Ford, T.R., 1977, Springs and fractures as an indication of potentially productive wells in the Piceance Basin, Northwest Colorado [abs.]: Ground Water, v. 15 , no. 4 , p. 326. 
Tobin, R.L., Stranathan, H.E., and Covay, K.J., 1985, Waterquality characteristics of streams in the Piceance Creek and Yellow Creek Drainage Basins, Northwestern Colorado: U.S. Geological Survey Water-Resources Investigations Report 84-4261, 35 p.

Tobin, R.L., 1987, Water quality in the Piceance Basin, in Taylor, J.O., ed., Oil shale, water resources, and valuable minerals of the Piceance Basin, Colorado: U.S. Geological Survey Professional Paper 1310, p. 81-86.

U.S. Bureau of Land Management, 1984, Volume 1-Piceance Basin Resource Management Plan and Environmental Impact Statement: U.S. Department of the Interior, Bureau of Land Management, White River Resource Area, Colorado, 270 p. _, 1999, Draft Environmental Impact StatementYankee Gulch Sodium Minerals Project, to produce sodium products, Piceance Basin, right-of-way permit and COE Section 404 permit, Rio Blanco County, Colorado: EIS No. 99004.

Verbeek, E.R., and Grout, M.A., 1983a, Fracture history of the northern Piceance Creek basin, northwestern Colorado, in Gary, J.H., ed., Oil Shale Symposium Proceedings, v.16, Colorado School of Mines, Golden, Colorado, p. 26-44. 1983b, Fracture studies at C-a Mine, Piceance Creek basin, Colorado: Abstracts with Programs Geological Society of America, v.15, no.5, p. 375

, 1987, Systematic joints within oil shales and associated rocks of the Green River Formation, in Taylor, J.O., ed., Oil shale, water resources, and valuable minerals of the Piceance Basin, Colorado: U.S. Geological Survey Professional Paper 1310, p. 45-56.

Ward, J.R., and Harr, C.A., eds., 1990, Methods for collection and processing of surface-water and bed-material samples for physical and chemical analyses: U.S. Geological Survey Open-File Report 90-140, 71 p.

Welder, F.A., 1987, Unconsolidated deposits of the Piceance Basin, in Taylor, J.O., ed., Oil shale, water resources, and valuable minerals of the Piceance Basin, Colorado: U.S. Geological Survey Professional Paper 1310, p. 57-62.

Wilde, F.D., Radtke, D.B., Gibs, J., and Iwatsubo, R.T., eds., 1998, National field manual for the collection of waterquality data: U.S. Geological Techniques of WaterResources Investigations, book 9, chap. A1-A5.

Zellweger, G.W., Bencala, K.E., McKnight, D.M., Hirsch, R.M., and Kimball, B.A., 1988, Practical aspects of tracer experiments in acidic, metal enriched stream, in Mallard, G.E., ed., U.S. Geological Survey Toxic Substances Hydrology Program-Surface-Water Contamination, Open-File Report 87-764, p. 125-130 
DATA SECTION 

Table 5. Chemical data for synoptic samples collected in Piceance Creek Basin, December 4-7, 2000

[mg/L, milligrams per liter; $\mathrm{HCO}_{3}$, bicarbonate; $\mathrm{CaCO}_{3}$, calcium carbonate; nd, no data; mv, missing value; e, estimated; <, less than; $\mu \mathrm{g} / \mathrm{L}$, microgram per liter; pCi/L, picocurie per liter]

\begin{tabular}{|c|c|c|c|c|c|c|c|c|c|c|}
\hline \multirow{2}{*}{ Site name } & \multicolumn{2}{|c|}{ Sample collection } & \multirow{2}{*}{$\begin{array}{l}\text { Calcium, } \\
\text { dissolved } \\
(\mathrm{mg} / \mathrm{L})\end{array}$} & \multirow{2}{*}{$\begin{array}{c}\text { Mag- } \\
\text { nesium, } \\
\text { dissolved } \\
\text { (mg/L) }\end{array}$} & \multirow{2}{*}{$\begin{array}{l}\text { Sodium, } \\
\text { dissolved } \\
(\mathrm{mg} / \mathrm{L})\end{array}$} & \multirow{3}{*}{$\begin{array}{l}\text { Potas- } \\
\text { sium, } \\
\text { dissolved } \\
\text { (mg/L) }\end{array}$} & \multirow{3}{*}{$\begin{array}{c}\text { Bicar- } \\
\text { bonate } \\
(\mathrm{mg} / \mathrm{L} \text { as } \\
\left.\mathrm{HCO}_{3}\right)\end{array}$} & \multirow{3}{*}{$\begin{array}{c}\text { Alk- } \\
\text { alinity } \\
\text { (mg/L } \\
\text { as total } \\
\mathrm{CaCO}_{3} \text { ) }\end{array}$} & \multirow{3}{*}{$\begin{array}{l}\text { Sulfate, } \\
\text { dissolved } \\
\text { (mg/L) }\end{array}$} & \multirow{3}{*}{$\begin{array}{c}\text { Chloride, } \\
\text { dissolved } \\
(\mathrm{mg} / \mathrm{L})\end{array}$} \\
\hline & Date & Time & & & & & & & & \\
\hline \multicolumn{6}{|c|}{ Main-stem sites } & & & & & \\
\hline PCO & $12-07-00$ & 1040 & 93 & 79 & 150 & 2.4 & 570 & 420 & 390 & 14.9 \\
\hline PC 180 & $12-07-00$ & 1035 & 91 & 81 & 160 & 2.4 & 600 & 420 & 410 & 15.6 \\
\hline PC420 & $12-07-00$ & 1030 & 92 & 81 & 160 & 2.4 & 560 & 420 & 410 & 15.5 \\
\hline PC660 & $12-07-00$ & 1020 & 90 & 80 & 150 & 2.4 & 560 & 410 & 410 & 15.0 \\
\hline PC 1,080 & $12-07-00$ & 1015 & 91 & 81 & 160 & $\mathrm{mv}$ & 590 & 440 & 410 & 15.9 \\
\hline $\mathrm{PC} 1,320$ & $12-07-00$ & 1005 & 94 & 84 & 160 & 2.5 & 590 & 440 & 420 & 14.7 \\
\hline $\mathrm{PC} 1,560$ & $12-07-00$ & 0955 & 90 & 82 & .160 & 2.4 & 580 & 430 & 410 & 16.2 \\
\hline PC 1,960 & $12-07-00$ & 0945 & 91 & 82 & 160 & 2.4 & 570 & 440 & 410 & 16.0 \\
\hline PC2,205 & $12-07-00$ & 0935 & 87 & 80 & 160 & 2.5 & 600 & 470 & 420 & 16.3 \\
\hline PC2,445 & $12-07-00$ & 0925 & 91 & 83 & 160 & 2.5 & 570 & 430 & 410 & 16.3 \\
\hline PC2,685 & $12-07-00$ & 0920 & 91 & 83 & 160 & 2.4 & 590 & 440 & 420 & 16.0 \\
\hline PC2,925 & $12-07-00$ & 0910 & 94 & 85 & 170 & 2.4 & 600 & 420 & 420 & 16.4 \\
\hline PC 3,105 & $12-07-00$ & 0900 & 93 & 85 & 170 & 2.4 & 590 & 420 & 420 & 16.4 \\
\hline PC 3,278 & $12-07-00$ & 0845 & 92 & 85 & 170 & 2.5 & 610 & 430 & 420 & 16.1 \\
\hline PC3,505 & $12-07-00$ & 0835 & 92 & 84 & 170 & 2.4 & 600 & 440 & 420 & 16.2 \\
\hline PC3,735 & $12-07-00$ & 0825 & 94 & 85 & 170 & 2.4 & 590 & 420 & 410 & 15.2 \\
\hline PC 3,935 & $12-07-00$ & 0815 & 89 & 82 & 170 & 2.5 & 610 & 440 & 420 & 16.8 \\
\hline PC4,180 & $12-07-00$ & 0800 & 88 & 84 & 180 & 2.4 & 610 & 470 & 420 & 16.5 \\
\hline $\mathrm{PC} 4,420$ & $12-07-00$ & 0755 & 90 & 82 & 160 & 2.4 & 570 & 450 & 410 & 16.6 \\
\hline PC4,660 & $12-07-00$ & 0745 & 90 & 82 & 170 & 2.4 & 600 & 450 & 400 & 16.2 \\
\hline PC4,900 & $12-07-00$ & 0735 & 93 & 84 & 170 & 2.4 & 610 & 450 & 410 & 14.8 \\
\hline PC5,040 & $12-07-00$ & 0727 & 90 & 81 & 160 & 2.4 & $\mathrm{mv}$ & 440 & 410 & 16.2 \\
\hline PC5,280 & $12-07-00$ & 0700 & 89 & 79 & 170 & 2.4 & $\mathrm{mv}$ & 480 & 420 & 16.8 \\
\hline PC6,625 & $12-07-00$ & 1147 & 88 & 82 & 180 & 2.5 & 600 & 450 & 420 & 17.5 \\
\hline PC6,625 & $12-05-00$ & 1040 & 87 & 84 & 180 & 2.5 & 650 & 480 & 410 & 18.1 \\
\hline PC6,813 & $12-05-00$ & 1020 & 87 & 84 & $\mathrm{mv}$ & 2.3 & 660 & 480 & 420 & 17.5 \\
\hline PC7,028 & $12-05-00$ & 1010 & 87 & 86 & $\mathrm{mv}$ & 2.4 & 650 & 460 & 420 & 18.0 \\
\hline PC7,248 & $12-05-00$ & 0955 & 89 & 87 & $\mathrm{mv}$ & 2.5 & 640 & 480 & 420 & 17.9 \\
\hline PC7,498 & $12-05-00$ & 0945 & 87 & 85 & $\mathrm{mv}$ & 2.4 & 660 & 480 & 420 & 17.3 \\
\hline PC7,738 & $12-05-00$ & 0935 & 88 & 85 & $\mathrm{mv}$ & 2.3 & 650 & 470 & 410 & 17.6 \\
\hline PC7,978 & $12-05-00$ & 0930 & 88 & 86 & $\mathrm{mv}$ & 2.5 & 620 & 470 & 420 & 18.0 \\
\hline PC 8,098 & $12-05-00$ & 0915 & 92 & 86 & $\mathrm{mv}$ & 2.4 & 660 & 510 & 430 & 18.2 \\
\hline PC 8,448 & $12-05-00$ & 0905 & 87 & 87 & $\mathrm{mv}$ & 2.6 & 620 & 480 & 420 & 18.0 \\
\hline PC 8,688 & $12-05-00$ & 0855 & 87 & 86 & $\mathrm{mv}$ & 2.4 & 650 & 490 & 420 & 18.0 \\
\hline PC8,938 & $12-05-00$ & 0850 & 86 & 86 & $\mathrm{mv}$ & 2.4 & 620 & 470 & 430 & 18.3 \\
\hline PC9,298 & $12-05-00$ & 0825 & 85 & 85 & $\mathrm{mv}$ & 2.4 & 630 & 480 & 420 & 18.3 \\
\hline PC9,608 & $12-05-00$ & 0815 & 80 & 82 & $\mathrm{mv}$ & 2.5 & 660 & 490 & 410 & 18.4 \\
\hline PC9,938 & $12-05-00$ & 0805 & 85 & 87 & $\mathrm{mv}$ & 2.5 & 680 & 490 & 420 & 18.5 \\
\hline $\mathrm{PC} 10,328$ & $12-05-00$ & 0800 & 82 & 82 & $\mathrm{mv}$ & 2.5 & 660 & 500 & 420 & 18.5 \\
\hline PC 10,748 & $12-05-00$ & 0745 & 84 & 83 & $\mathrm{mv}$ & 2.4 & 660 & 470 & 430 & 18.6 \\
\hline PC1 1,483 & $12-05-00$ & 0730 & 86 & 81 & $\mathrm{mv}$ & 2.5 & 670 & 500 & 430 & 18.8 \\
\hline
\end{tabular}


Table 5. Chemical data for synoptic samples collected in Piceance Creek Basin, December 4-7, 2000—Continued $\left[\mathrm{mg} / \mathrm{L}\right.$, milligrams per liter; $\mathrm{HCO}_{3}$, bicarbonate; $\mathrm{CaCO}_{3}$, calcium carbonate; nd, no data; mv, missing value; e, estimated; <, less than; $\mu \mathrm{g} / \mathrm{L}$, microgram per liter; $\mathrm{pCi} / \mathrm{L}$, picocurie per liter]

\begin{tabular}{|c|c|c|c|c|c|c|c|c|c|c|c|}
\hline Site name & Sample c & llection & $\begin{array}{c}\text { Calcium, } \\
\text { dissolved } \\
(\mathrm{mg} / \mathrm{L})\end{array}$ & \multicolumn{2}{|c|}{$\begin{array}{c}\text { Mag- } \\
\text { nesium, } \\
\text { dissolved } \\
\text { (mg/L) }\end{array}$} & $\begin{array}{l}\text { Sodium, } \\
\text { dissolved } \\
(\mathrm{mg} / \mathrm{L})\end{array}$ & $\begin{array}{l}\text { Potas- } \\
\text { sium, } \\
\text { dissolved } \\
\text { (mg/L) }\end{array}$ & \multirow[t]{2}{*}{$\begin{array}{c}\text { Bicar- } \\
\text { bonate } \\
(\mathrm{mg} / \mathrm{L} \text { as } \\
\left.\mathrm{HCO}_{3}\right)\end{array}$} & \multirow[t]{2}{*}{$\begin{array}{c}\text { Alk- } \\
\text { alinity } \\
\text { (mg/L } \\
\text { as total } \\
\mathrm{CaCO}_{3} \text { ) }\end{array}$} & \multirow[t]{2}{*}{$\begin{array}{c}\text { Sulfate, } \\
\text { dissolved } \\
\text { (mg/L) }\end{array}$} & \multirow[t]{2}{*}{$\begin{array}{c}\text { Chloride, } \\
\text { dissolved } \\
\text { (mg/L) }\end{array}$} \\
\hline \multicolumn{8}{|c|}{ Main-stem sites-Continued } & & & & \\
\hline $\mathrm{PC} 14,789$ & $12-06-00$ & 1005 & 79 & 8 & & 200 & 2.5 & $\mathrm{mv}$ & 480 & 430 & 19.2 \\
\hline $\mathrm{PC} 16,210$ & $12-06-00$ & 0910 & 84 & 8 & & 200 & 2.5 & $\mathrm{mv}$ & 520 & 430 & 19.1 \\
\hline $\mathrm{PC} 17,860$ & $12-06-00$ & 0805 & 86 & 8 & & 200 & 2.4 & $\mathrm{mv}$ & 520 & 430 & 20.0 \\
\hline PC20,708 & $12-06-00$ & 1030 & 81 & 8 & & 200 & 2.5 & 720 & 490 & 410 & 20.1 \\
\hline PC23,721 & $12-06-00$ & 0945 & 81 & 7 & & 270 & 2.5 & 860 & 650 & 410 & 37.9 \\
\hline PC24,787 & $12-06-00$ & 0900 & 83 & 8 & & 270 & 2.5 & 800 & 590 & 410 & 33.6 \\
\hline PC28,348 & $12-06-00$ & 0745 & 82 & 8 & & 80 & 2.6 & $\mathrm{mv}$ & 600 & 420 & 34.4 \\
\hline \multicolumn{12}{|c|}{ Input sites } \\
\hline RGS & $12-04-00$ & 0900 & 110 & 20 & & 360 & 1.8 & $\mathrm{mv}$ & 640 & 1,210 & 24.9 \\
\hline HGS & $12-07-00$ & 1220 & 32 & 10 & & 50 & 1.9 & 1,570 & 1,290 & 700 & 43.9 \\
\hline PT 16,225 & $12-06-00$ & 0925 & 73 & 5 & & 10 & 2.0 & 370 & 330 & 240 & 15.2 \\
\hline AFS & $12-04-00$ & 1225 & 17 & 4 & & 40 & 7.3 & $\mathrm{mv}$ & 6,860 & 100 & 900 \\
\hline Site name & Sample co & Time & $\begin{array}{c}\text { Fluoride, } \\
\text { dis- } \\
\text { solved } \\
\text { (mg/L) }\end{array}$ & $\begin{array}{c}\text { Bro- } \\
\text { mide, } \\
\text { dis- } \\
\text { solved } \\
\text { (mg/L) }\end{array}$ & $\begin{array}{c}\text { Silica, } \\
\text { dis- } \\
\text { solved } \\
\text { (mg/L) }\end{array}$ & $\begin{array}{c}\text { Total } \\
\text { dis- } \\
\text { solved } \\
\text { solids } \\
\text { (mg/L) }\end{array}$ & $\begin{array}{l}\text { Nitrite, } \\
\text { dis- } \\
\text { solved } \\
\text { (mg/L) }\end{array}$ & $\begin{array}{c}\text { Nitrite } \\
\text { plus } \\
\text { nitrate, } \\
\text { dis- } \\
\text { solved } \\
\text { (mg/L) }\end{array}$ & $\begin{array}{c}\text { Am- } \\
\text { monia, } \\
\text { dis- } \\
\text { solved } \\
(\mathrm{mg} / \mathrm{L})\end{array}$ & $\begin{array}{l}\text { Ammonia } \\
\text { plus } \\
\text { organic } \\
\text { nitrogen, } \\
\text { dissolved } \\
\text { (mg/L) }\end{array}$ & $\begin{array}{c}\text { Phos- } \\
\text { phorus, } \\
\text { dis- } \\
\text { solved } \\
\text { (mg/L) }\end{array}$ \\
\hline \multicolumn{12}{|c|}{ Main-stem sites } \\
\hline PC0 & $12-07-00$ & 1040 & 0.61 & 0.10 & 16.4 & 1,000 & nd & nd & nd & nd & nd \\
\hline PC180 & $12-07-00$ & 1035 & .93 & $\mathrm{mv}$ & 16.6 & 1,030 & nd & nd & nd & nd & nd \\
\hline PC420 & $12-07-00$ & 1030 & .59 & $\mathrm{mv}$ & 16.6 & 1,030 & nd & nd & nd & nd & nd \\
\hline PC660 & $12-07-00$ & 1020 & .59 & $\mathrm{mv}$ & 16.5 & 1,020 & nd & nd & nd & nd & nd \\
\hline PC 1,080 & $12-07-00$ & 1015 & .63 & $\mathrm{mv}$ & 16.6 & 1,050 & nd & nd & nd & nd & nd \\
\hline PC1,320 & $12-07-00$ & 1005 & .59 & $\mathrm{mv}$ & 16.6 & 1,060 & nd & nd & nd & nd & nd \\
\hline PC 1,560 & $12-07-00$ & 0955 & .59 & $\mathrm{mv}$ & 16.8 & 1,040 & nd & nd & nd & nd & nd \\
\hline PC1,960 & $12-07-00$ & 0945 & .62 & $\mathrm{mv}$ & 16.7 & 1,050 & nd & nd & nd & nd & nd \\
\hline PC2,205 & $12-07-00$ & 0935 & .67 & $\mathrm{mv}$ & 17.0 & 1,080 & .01 & .69 & e. .04 & .28 & $<.06$ \\
\hline PC2,445 & $12-07-00$ & 0925 & .94 & $\mathrm{mv}$ & 16.7 & 1,050 & nd & nd & nd & nd & nd \\
\hline PC2,685 & $12-07-00$ & 0920 & .61 & $\mathrm{mv}$ & 16.9 & 1,060 & nd & nd & nd & nd & nd \\
\hline PC 2,925 & $12-07-00$ & 0910 & .60 & $\mathrm{mv}$ & 16.5 & 1,060 & nd & nd & nd & nd & nd \\
\hline PC 3,105 & $12-07-00$ & 0900 & .59 & $\mathrm{mv}$ & 17.0 & 1,060 & nd & nd & nd & nd & nd \\
\hline PC 3,278 & $12-07-00$ & 0845 & .60 & $\mathrm{mv}$ & 16.8 & 1,060 & nd & nd & nd & nd & nd \\
\hline PC 3,505 & $12-07-00$ & 0835 & .92 & $\mathrm{mv}$ & 17.7 & 1,070 & nd & nd & nd & nd & nd \\
\hline PC 3,735 & $12-07-00$ & 0825 & .60 & $\mathrm{mv}$ & 16.4 & 1,050 & nd & nd & nd & nd & nd \\
\hline PC 3,935 & $12-07-00$ & 0815 & 1.19 & $\mathrm{mv}$ & 16.6 & 1,060 & nd & nd & nd & nd & nd \\
\hline PC4,180 & $12-07-00$ & 0800 & .68 & $\mathrm{mv}$ & 16.8 & 1,100 & .01 & .67 & e .04 & .30 & $<.06$ \\
\hline PC4,420 & $12-07-00$ & 0755 & .64 & $\mathrm{mv}$ & 16.6 & $1,050^{\circ}$ & nd & nd & nd & nd & nd \\
\hline PC4,660 & $12-07-00$ & 0745 & .62 & $\mathrm{mv}$ & 16.5 & 1,050 & nd & nd & nd & nd & nd \\
\hline PC4,900 & $12-07-00$ & 0735 & .63 & $\mathrm{mv}$ & 16.7 & 1,070 & nd & nd & nd & nd & nd \\
\hline PC5,040 & $12-07-00$ & 0727 & .61 & $\mathrm{mv}$ & 16.5 & 1,050 & nd & nd & nd & nd & nd \\
\hline PC5,280 & $12-07-00$ & 0700 & .59 & $\mathrm{mv}$ & 16.5 & 1,100 & .01 & .66 & .05 & .32 & $<.06$ \\
\hline
\end{tabular}


Table 5. Chemical data for synoptic samples collected in Piceance Creek Basin, December 4-7, 2000-Continued [mg/L, milligrams per liter; $\mathrm{HCO}_{3}$, bicarbonate; $\mathrm{CaCO}_{3}$, calcium carbonate; nd, no data; mv, missing value; e, estimated; <, less than; $\mu \mathrm{g} / \mathrm{L}$, microgram per liter; pCi/L, picocurie per liter]

\begin{tabular}{|c|c|c|c|c|c|c|c|c|c|c|c|c|}
\hline Site name & Sample & e collec & ction & $\begin{array}{l}\text { Fluoride, } \\
\text { dis- } \\
\text { solved } \\
\text { (mg/L) }\end{array}$ & $\begin{array}{c}\text { Bro- } \\
\text { mide, } \\
\text { dis- } \\
\text { solved } \\
\text { (mg/L) }\end{array}$ & $\begin{array}{l}\text { Silica, } \\
\text { dis- } \\
\text { solved } \\
(\mathrm{mg} / \mathrm{L})\end{array}$ & $\begin{array}{l}\text { Total } \\
\text { dis- } \\
\text { solved } \\
\text { solids } \\
\text { (mg/L) }\end{array}$ & $\begin{array}{l}\text { Nitrite, } \\
\text { dis- } \\
\text { solved } \\
\text { (mg/L) }\end{array}$ & $\begin{array}{c}\text { Nitrite } \\
\text { plus } \\
\text { nitrate, } \\
\text { dis- } \\
\text { solved } \\
\text { (mg/L) }\end{array}$ & $\begin{array}{c}\text { Am- } \\
\text { monia, } \\
\text { dis- } \\
\text { solved } \\
\text { (mg/L) }\end{array}$ & $\begin{array}{l}\text { Ammonia } \\
\text { plus } \\
\text { organic } \\
\text { nitrogen, } \\
\text { dissolved } \\
\text { (mg/L) }\end{array}$ & $\begin{array}{l}\text { Phos- } \\
\text { phorus, } \\
\text { dis- } \\
\text { solved } \\
\text { (mg/L) }\end{array}$ \\
\hline \multicolumn{13}{|c|}{ Main-stem sites-Continued } \\
\hline PC6,625 & \multicolumn{2}{|c|}{$12-07-00$} & 1147 & 0.59 & $\mathrm{mv}$ & 16.5 & 1,080 & nd & nd & nd & nd & nd \\
\hline PC6,625 & \multicolumn{2}{|c|}{$12-05-00$} & 1040 & 1.15 & $\mathrm{mv}$ & 16.7 & 1,100 & nd & nd & nd & nd & nd \\
\hline PC6,813 & \multicolumn{2}{|c|}{$12-05-00$} & 1020 & .60 & $\mathrm{mv}$ & 16.6 & 1,100 & nd & nd & nd & nd & nd \\
\hline PC7,028 & \multicolumn{2}{|c|}{$12-05-00$} & 1010 & .65 & $\mathrm{mv}$ & 16.7 & 1,100 & nd & nd & nd & nd & nd \\
\hline PC7,248 & \multicolumn{2}{|c|}{$12-05-00$} & 0955 & .66 & $\mathrm{mv}$ & 16.7 & 1,110 & nd & nd & nd & nd & nd \\
\hline PC7,498 & \multicolumn{2}{|c|}{$12-05-00$} & 0945 & .66 & $\mathrm{mv}$ & 16.6 & 1,100 & nd & nd & nd & nd & nd \\
\hline PC7,738 & \multicolumn{2}{|c|}{$12-05-00$} & 0935 & .57 & $\mathrm{mv}$ & 16.5 & 1,090 & nd & nd & nd & nd & nd \\
\hline PC7,978 & \multicolumn{2}{|c|}{$12-05-00$} & 0930 & .64 & $\mathrm{mv}$ & 15.3 & 1,110 & nd & nd & nd & nd & nd \\
\hline PC8,098 & \multicolumn{2}{|c|}{$12-05-00$} & 0915 & .69 & $\mathrm{mv}$ & 16.5 & 1,160 & .01 & .66 & .06 & .32 & $<.06$ \\
\hline PC 8,448 & \multicolumn{2}{|c|}{$12-05-00$} & 0905 & .64 & $\mathrm{mv}$ & 18.2 & 1,120 & nd & nd & nd & nd & nd \\
\hline PC8,688 & \multicolumn{2}{|c|}{$12-05-00$} & 0855 & .58 & $\mathrm{mv}$ & 16.9 & 1,120 & nd & nd & nd & nd & nd \\
\hline PC8,938 & $12-05-$ & & 0850 & .62 & $\mathrm{mv}$ & 16.0 & 1,120 & nd & nd & nd & nd & nd \\
\hline PC9,298 & $12-05-$ & & 0825 & .67 & $\mathrm{mv}$ & 16.6 & 1,110 & nd & nd & nd & nd & nd \\
\hline PC9,608 & $12-05-$ & & 0815 & .66 & $\mathrm{mv}$ & 16.1 & 1,100 & nd & nd & nd & nd & nd \\
\hline РC9,938 & $12-05-$ & & 0805 & .69 & $\mathrm{mv}$ & 16.6 & 1,130 & nd & nd & nd & nd & nd \\
\hline PC10,328 & $12-05-$ & & 0800 & .63 & $\mathrm{mv}$ & 15.9 & 1,110 & nd & nd & nd & nd & nd \\
\hline PC10,748 & $12-05-$ & & 0745 & .66 & $\mathrm{mv}$ & 17.0 & 1,110 & nd & nd & nd & nd & nd \\
\hline PC 11,483 & $12-05-$ & & 0730 & .69 & $\mathrm{mv}$ & 16.8 & 1,150 & .01 & .61 & .06 & .33 & $<.06$ \\
\hline $\mathrm{PC} 14,789$ & $12-06-$ & & 1005 & .64 & .10 & 17.0 & 1,130 & nd & nd & nd & nd & nd \\
\hline $\mathrm{PC} 16,210$ & $12-06-$ & & 0910 & .67 & .09 & 16.8 & 1,160 & nd & nd & nd & nd & nd \\
\hline $\mathrm{PC} 17,860$ & $12-06-$ & & 0805 & .68 & .12 & 17.0 & 1,150 & .01 & .70 & .06 & .37 & $<.06$ \\
\hline PC20,708 & $12-06-$ & & 1030 & .67 & .09 & 16.8 & 1,110 & nd & nd & nd & nd & nd \\
\hline PC 23,721 & $12-06-$ & & 0945 & .90 & .12 & 16.9 & 1,300 & .01 & .67 & .15 & .49 & e .05 \\
\hline PC 24,787 & $12-06-$ & & 0900 & .86 & .13 & 16.4 & 1,260 & nd & nd & nd & nd & nd \\
\hline PC28,348 & $12-06-$ & & 0745 & .79 & .19 & 17.3 & 1,290 & nd & nd & nd & nd & nd \\
\hline & & & & & & & put sites & & & & & \\
\hline RGS & $12-04-$ & & 0900 & .37 & .20 & 21.6 & 2,310 & nd & nd & nd & nd & nd \\
\hline HGS & $12-07-$ & & 1220 & 2.77 & .20 & 15.5 & 2,330 & nd & nd & nd & nd & nd \\
\hline PT16,225 & $12-06-$ & & 0925 & .40 & .11 & 16.4 & 710 & nd & nd & nd & nd & nd \\
\hline AFS & $12-04-$ & & 1225 & 15.5 & .69 & .8 & 8,760 & nd & nd & nd & nd & nd \\
\hline Site name & Sample co & Ilection & $\begin{array}{r}\text { Or } \\
\text { pl } \\
\text { ph } \\
\text { diss } \\
\text { (m }\end{array}$ & $\begin{array}{l}\text { rtho- } \\
\text { hos- } \\
\text { orus, } \\
\text { solved dis } \\
\text { ig/L) }\end{array}$ & $\begin{array}{l}\text { Alum- } \\
\text { inum, } \\
\text { ssolved } \\
(\mu \mathrm{g} / \mathrm{L})\end{array}$ & $\begin{array}{c}\text { Anti- } \\
\text { mony, } \\
\text { dissolved } \\
(\mu \mathrm{g} / \mathrm{L})\end{array}$ & $\begin{array}{l}\text { Arsenic, } \\
\text { dissolved } \\
(\mu \mathrm{g} / \mathrm{L})\end{array}$ & $\begin{array}{c}\text { Barium, } \\
\text { dissolved } \\
(\mu \mathrm{g} / L)\end{array}$ & $\begin{array}{c}\text { Beryllium, } \\
\text { dissolved } \\
(\mu \mathrm{g} / \mathrm{L})\end{array}$ & $\begin{array}{c}\text { Boron, } \\
\text { dissolved } \\
(\mu \mathrm{g} / \mathrm{L})\end{array}$ & $\begin{array}{c}\text { Cad- } \\
\text { mium, } \\
\text { dissolved } \\
(\mu \mathrm{g} / \mathrm{L})\end{array}$ & $\begin{array}{c}\text { Chro- } \\
\text { mium, } \\
\text { dissolved } \\
(\mu \mathrm{g} / L)\end{array}$ \\
\hline & & & & & & Main & 1-stem sites & & & & & \\
\hline PCO & $12-07-00$ & 1040 & & nd & $\mathrm{mv}$ & 0.11 & 1.7 & 75 & nd & 160 & nd & nd \\
\hline PC180 & $12-07-00$ & 1035 & & nd & $\mathrm{mv}$ & .16 & 1.2 & 73 & nd & 160 & nd & nd \\
\hline PC420 & $12-07-00$ & 1030 & & nd & $\mathrm{mv}$ & .12 & 1.2 & 73 & nd & 160 & nd & nd \\
\hline PC660 & $12-07-00$ & 1020 & & nd & $\mathrm{mv}$ & .13 & 1.2 & 72 & nd & 160 & nd & nd \\
\hline PC 1,080 & $12-07-00$ & 1015 & & nd & $\mathrm{mv}$ & .13 & 1.1 & 73 & nd & 160 & nd & nd \\
\hline PC1,320 & $12-07-00$ & 1005 & & nd & $\mathrm{mv}$ & .12 & 1.2 & 74 & nd & 170 & nd & nd \\
\hline
\end{tabular}


Table 5. Chemical data for synoptic samples collected in Piceance Creek Basin, December 4-7, 2000_Continued [mg/L, milligrams per liter; $\mathrm{HCO}_{3}$, bicarbonate; $\mathrm{CaCO}_{3}$, calcium carbonate; nd, no data; mv, missing value; e, estimated; <, less than; $\mu \mathrm{g} / \mathrm{L}$, microgram per liter; $\mathrm{pCi} / \mathrm{L}$, picocurie per liter]

\begin{tabular}{|c|c|c|c|c|c|c|c|c|c|c|c|}
\hline Site name & Sample co & $\begin{array}{l}\text { llection } \\
\text { Time }\end{array}$ & $\begin{array}{l}\text { Ortho- } \\
\text { phos- } \\
\text { phorus, } \\
\text { dissolved } \\
\text { (mg/L) }\end{array}$ & $\begin{array}{c}\text { Alum- } \\
\text { inum, } \\
\text { dissolved } \\
(\mu \mathrm{g} / \mathrm{L})\end{array}$ & $\begin{array}{c}\text { Anti- } \\
\text { mony, } \\
\text { dissolved } \\
(\mu \mathrm{g} / \mathrm{L})\end{array}$ & $\begin{array}{c}\text { Arsenic, } \\
\text { dissolved } \\
(\mu \mathrm{g} / \mathrm{L})\end{array}$ & $\begin{array}{c}\text { Barium, } \\
\text { dissolved } \\
(\mu \mathrm{g} / L)\end{array}$ & $\begin{array}{c}\text { Beryllium, } \\
\text { dissolved } \\
(\mu \mathrm{g} / \mathrm{L})\end{array}$ & $\begin{array}{c}\text { Boron, } \\
\text { dissolved } \\
(\mu \mathrm{g} / \mathrm{L})\end{array}$ & $\begin{array}{c}\text { Cad- } \\
\text { mium, } \\
\text { dissolved } \\
(\mu \mathrm{g} / L)\end{array}$ & $\begin{array}{c}\text { Chro- } \\
\text { mium, } \\
\text { dissolved } \\
(\mu \mathrm{g} / \mathrm{L})\end{array}$ \\
\hline \multicolumn{12}{|c|}{ Main-stem sites-Continued } \\
\hline PC1,560 & $12-07-00$ & 0955 & nd & $\mathrm{mv}$ & 0.13 & . $\quad 1.2$ & 72 & nd & 160 & nd & nd \\
\hline $\mathrm{PC} 1,960$ & $12-07-00$ & 0945 & nd & $\mathrm{mv}$ & .12 & 1.2 & 74 & nd & 160 & nd & nd \\
\hline PC2,205 & $12-07-00$ & 0935 & 0.02 & $\mathrm{mv}$ & .12 & e 2.0 & 74 & $<0.06$ & 170 & 0.04 & $<0.8$ \\
\hline PC2,445 & $12-07-00$ & 0925 & nd & $\mathrm{mv}$ & .11 & 1.1 & 73 & nd & 170 & nd & nd \\
\hline $\mathrm{PC} 2,685$ & $12-07-00$ & 0920 & nd & $\mathrm{mv}$ & .12 & 1.3 & 74 & nd & 170 & nd & nd \\
\hline PC2,925 & $12-07-00$ & 0910 & nd & $\mathrm{mv}$ & .12 & 1.3 & 73 & nd & 180 & nd & nd \\
\hline PC3,105 & $12-07-00$ & 0900 & nd & $\mathrm{mv}$ & .11 & 1.4 & 73 & nd & 170 & nd & nd \\
\hline PC 3,278 & $12-07-00$ & 0845 & nd & $\mathrm{mv}$ & .19 & 1.4 & 73 & nd & 160 & nd & nd \\
\hline PC3,505 & $12-07-00$ & 0835 & nd & $\mathrm{mv}$ & .15 & 1.3 & 73 & nd & 170 & nd & nd \\
\hline PC 3,735 & $12-07-00$ & 0825 & nd & $\mathrm{mv}$ & .11 & 1.3 & 74 & nd & 170 & nd & nd \\
\hline PC 3,935 & $12-07-00$ & 0815 & nd & $\mathrm{mv}$ & .11 & 1.5 & 74 & nd & 170 & nd & nd \\
\hline PC4, 180 & $12-07-00$ & 0800 & .02 & $\mathrm{mv}$ & .12 & 2.1 & 75 & $<.06$ & 200 & .04 & $<.8$ \\
\hline PC4,420 & $12-07-00$ & 0755 & nd & $\mathrm{mv}$ & .13 & 1.4 & 74 & nd & 160 & nd & nd \\
\hline PC4,660 & $12-07-00$ & 0745 & nd & $\mathrm{mv}$ & .12 & 1.5 & 74 & nd & 170 & nd & nd \\
\hline PC4,900 & $12-07-00$ & 0735 & nd & $\mathrm{mv}$ & .12 & 1.3 & 73 & nd & 170 & nd & nd \\
\hline PC5,040 & $12-07-00$ & 0727 . & nd & $\mathrm{mv}$ & .12 & 1.4 & 73 & nd & 160 & nd & nd \\
\hline PC5,280 & $12-07-00$ & 0700 & .02 & $\mathrm{mv}$ & .12 & e 1.9 & 76 & $<.06$ & 170 & .05 & $<.8$ \\
\hline PC6,625 & $12-07-00$ & 1147 & nd & $\mathrm{mv}$ & .12 & 1.5 & 86 & nd & 170 & nd & nd \\
\hline PC6,625 & $12-05-00$ & 1040 & nd & $<1.0$ & .11 & 1.7 & 78 & nd & 190 & nd & nd \\
\hline PC6,813 & $12-05-00$ & 1020 & nd & 1.1 & .13 & 2.1 & 78 & nd & 180 & nd & nd \\
\hline PC7,028 & $12-05-00$ & 1010 & nd & 1.0 & .12 & 1.6 & 74 & nd & 180 & nd & nd \\
\hline PC7,248 & $12-05-00$ & 0955 & nd & 2.2 & $<.05$ & 2.3 & 80 & nd & 190 & nd & nd \\
\hline PC7,498 & $12-05-00$ & 0945 & nd & 1.6 & $<.05$ & 2.2 & 78 & nd & 180 & nd & nd \\
\hline PC7,738 & $12-05-00$ & 0935 & nd & 1.1 & .12 & 2.3 & 78 & nd & 180 & nd & nd \\
\hline PC7,978 & $12-05-00$ & 0930 & nd & 1.3 & $<.05$ & 2.3 & 78 & nd & 190 & nd & nd \\
\hline PC8,098 & $12-05-00$ & 0915 & .04 & 1.1 & .13 & e 1.9 & 79 & $<.06$ & 190 & .59 & $<.8$ \\
\hline PC 8,448 & $12-05-00$ & 0905 & nd & 1.3 & $<.05$ & 2.4 & 78 & nd & 190 & nd & nd \\
\hline PC8,688 & $12-05-00$ & 0855 & nd & $<1.0$ & .12 & 2.4 & 78 & nd & 180 & nd & nd \\
\hline PC8,938 & $12-05-00$ & 0850 & nd & 2.7 & $<.05$ & 2.4 & 79 & nd & 190 & nd & nd \\
\hline РC9,298 & $12-05-00$ & 0825 & nd & 1.7 & $<.05$ & 2.4 & 78 & nd & 190 & nd & nd \\
\hline PC9,608 & $12-05-00$ & 0815 & nd & $<1.0$ & .11 & 1.3 & 72 & nd & 180 & nd & nd \\
\hline PC9,938 & $12-05-00$ & 0805 & nd & $<1.0$ & .12 & 1.6 & 74 & nd & 200 & nd & nd \\
\hline PC 10,328 & $12-05-00$ & 0800 & nd & 2.3 & $<.05$ & 2.5 & 77 & nd & 190 & nd & nd \\
\hline PC 10,748 & $12-05-00$ & 0745 & nd & 1.4 & .16 & 1.6 & 78 & nd & 180 & nd & nd \\
\hline PC11,483 & $12-05-00$ & 0730 & .05 & $<1.0$ & .13 & e 1.9 & 81 & $<.06$ & 180 & e .03 & $<.8$ \\
\hline $\mathrm{PC} 14,789$ & $12-06-00$ & 1005 & nd & 1.2 & .18 & 2.0 & 79 & nd & 190 & nd & nd \\
\hline $\mathrm{PC} 16,210$ & $12-06-00$ & 0910 & nd & 1.5 & $<.05$ & 2.4 & 79 & nd & 190 & nd & nd \\
\hline PC 17,860 & $12-06-00$ & 0805 & .03 & $<1.0$ & .13 & e 1.7 & 81 & $<.06$ & 190 & e .03 & e .5 \\
\hline PC20,708 & $12-06-00$ & 1030 & nd & 1.3 & $<.05$ & 2.2 & 82 & nd & 190 & nd & nd \\
\hline PC23,721 & $12-06-00$ & 0945 & .06 & $<1.0$ & .14 & e 1.8 & 110 & $<.06$ & 220 & .20 & $<.8$ \\
\hline PC24,787 & $12-06-00$ & 0900 & nd & 1.2 & $<.05$ & 2.6 & 100 & nd & 230 & nd & nd \\
\hline PC28,348 & $12-06-00$ & 0745 & nd & 1.2 & .17 & 2.0 & 100 & nd & 260 & nd & nd \\
\hline
\end{tabular}


Table 5. Chemical data for synoptic samples collected in Piceance Creek Basin, December 4-7, 2000-Continued $\left[\mathrm{mg} / \mathrm{L}\right.$, milligrams per liter; $\mathrm{HCO}_{3}$, bicarbonate; $\mathrm{CaCO}_{3}$, calcium carbonate; nd, no data; mv, missing value; e, estimated; <, less than; $\mu \mathrm{g} / \mathrm{L}$, microgram per liter; $\mathrm{pCi} / \mathrm{L}$, picocurie per liter]

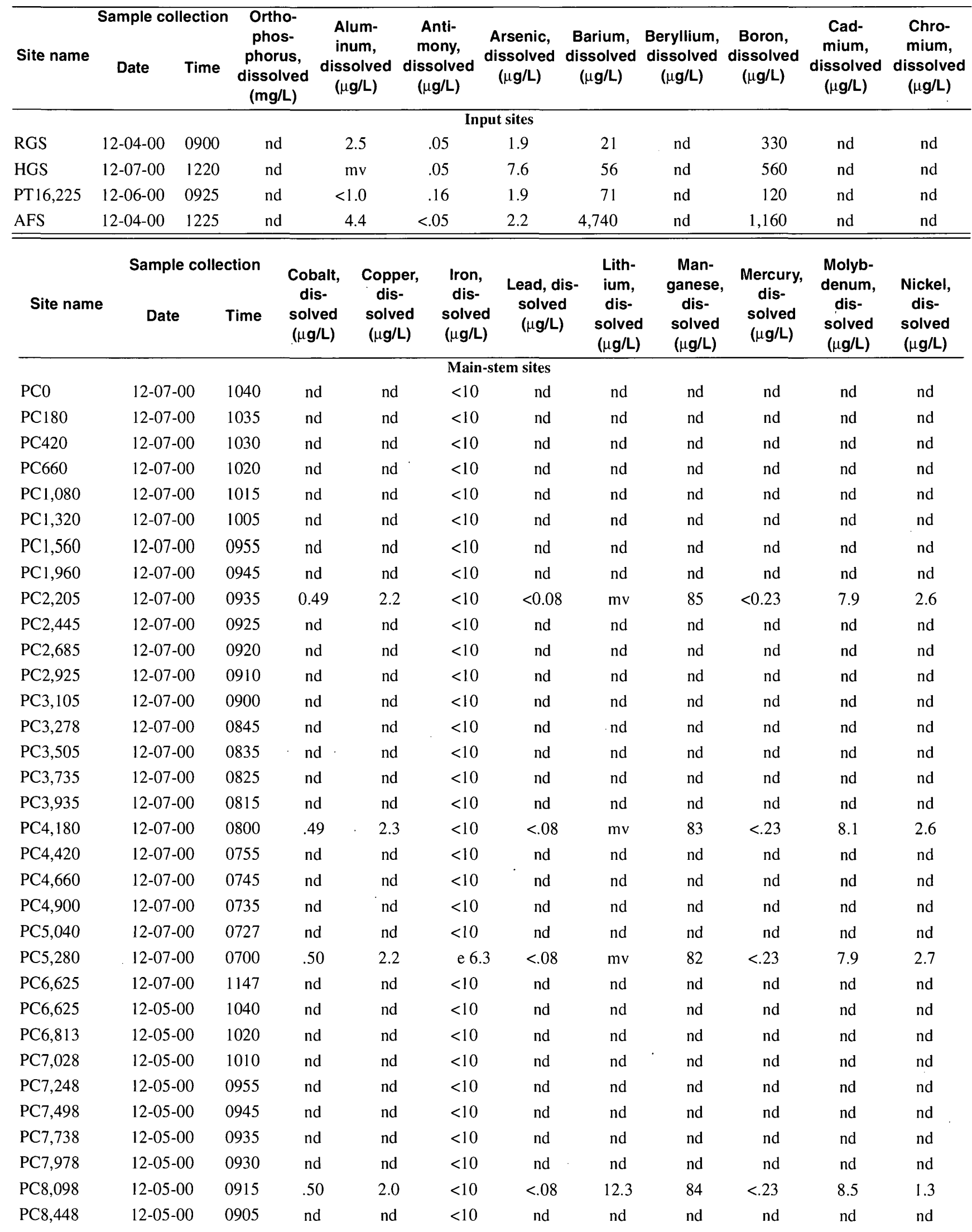


Table 5. Chemical data for synoptic samples collected in Piceance Creek Basin, December 4-7, 2000—Continued [mg/L, milligrams per liter; $\mathrm{HCO}_{3}$, bicarbonate; $\mathrm{CaCO}_{3}$, calcium carbonate; nd, no data; mv, missing value; e, estimated; <, less than; $\mu \mathrm{g} / \mathrm{L}$, microgram per liter; $\mathrm{pCi} / \mathrm{L}$, picocurie per liter]

\begin{tabular}{|c|c|c|c|c|c|c|c|c|c|c|c|}
\hline Site name & Sample c & ollectio & $\begin{array}{c}\text { Cobalt, } \\
\text { dis- } \\
\text { solved } \\
(\mu \mathrm{g} / \mathrm{L})\end{array}$ & $\begin{array}{c}\text { Copper, } \\
\text { dis- } \\
\text { solved } \\
(\mu \mathrm{g} / \mathrm{L})\end{array}$ & $\begin{array}{l}\text { Iron, } \\
\text { dis- } \\
\text { solved } \\
(\mu \mathrm{g} / \mathrm{L})\end{array}$ & $\begin{array}{l}\text { Lead, dis- } \\
\text { solved } \\
(\mu \mathrm{g} / L)\end{array}$ & $\begin{array}{l}\text { Lith- } \\
\text { ium, } \\
\text { dis- } \\
\text { solved } \\
(\mu \mathrm{g} / \mathrm{L})\end{array}$ & $\begin{array}{c}\text { Man- } \\
\text { ganese, } \\
\text { dis- } \\
\text { solved } \\
(\mu \mathrm{g} / \mathrm{L})\end{array}$ & $\begin{array}{c}\text { Mercury, } \\
\text { dis- } \\
\text { solved } \\
(\mu \mathrm{g} / \mathrm{L})\end{array}$ & $\begin{array}{l}\text { Molyb- } \\
\text { denum, } \\
\text { dis- } \\
\text { solved } \\
(\mu \mathrm{g} / \mathrm{L})\end{array}$ & $\begin{array}{c}\text { Nickel, } \\
\text { dis- } \\
\text { solved } \\
(\mu \mathrm{g} / \mathrm{L})\end{array}$ \\
\hline \multicolumn{12}{|c|}{ Main-stem sites-Continued } \\
\hline PC8,688 & $12-05-00$ & 085 & nd & nd & $<10$ & nd & nd & nd & nd & nd & nd \\
\hline PC8,938 & $12-05-00$ & 085 & nd & nd & $<10$ & nd & nd & nd & nd & nd & nd \\
\hline PC9,298 & $12-05-00$ & 082 & nd & nd & $<10$ & nd & nd & nd & nd & nd & nd \\
\hline PC9,608 & $12-05-00$ & 081 & nd & nd & $<10$ & nd & nd & nd & nd & nd & nd \\
\hline PC 9,938 & $12-05-00$ & 080 & nd & nd & $<10$ & nd & nd & nd & nd & nd & nd \\
\hline PC10,328 & $12-05-00$ & 080 & nd & nd & $<10$ & nd & nd & nd & nd & nd & nd \\
\hline PC 10,748 & $12-05-00$ & 074 & nd & nd & $<10$ & nd & nd & nd & nd & nd & nd \\
\hline PC11,483 & $12-05-00$ & 073 & 0.52 & 2.0 & $<10$ & $<0.08$ & 11.9 & 79 & $<0.23$ & 8.8 & 1.4 \\
\hline PC14,789 & $12-06-00$ & 100 & nd & nd & $<10$ & nd & nd & nd & nd & nd & nd \\
\hline PC16,210 & $12-06-00$ & 091 & nd & nd & $<10$ & nd & nd & nd & nd & nd & nd \\
\hline $\mathrm{PC} 17,860$ & $12-06-00$ & 080 & .50 & 2.0 & $<10$ & $<.08$ & 12.8 & 74 & $<.23$ & 9.0 & 1.0 \\
\hline PC20,708 & $12-06-00$ & 103 & nd & nd & $<10$ & nd & nd & nd & nd & nd & nd \\
\hline PC23,721 & $12-06-00$ & 094 & .54 & 2.0 & $<10$ & e .04 & 21.7 & 72 & $<.23$ & 8.4 & 1.2 \\
\hline PC24,787 & $12-06-00$ & 090 & nd & nd & $<30$ & nd & nd & nd & nd & nd & nd \\
\hline PC28,348 & $12-06-00$ & 074 & nd & nd & $<30$ & nd & nd & nd & nd & nd & nd \\
\hline \multicolumn{12}{|c|}{ Input sites } \\
\hline RGS & $12-04-00$ & 090 & nd & nd & 30 & nd & nd & nd & nd & nd & nd \\
\hline HGS & $12-07-00$ & 122 & nd & nd & e 27 & nd & nd & nd & nd & nd & nd \\
\hline PT16,225 & $12-06-00$ & 092 & nd & nd & $<10$ & nd & nd & nd & nd & nd & nd \\
\hline AFS & $12-04-00$ & 122 & nd & nd & $<100$ & nd & nd & nd & nd & nd & nd \\
\hline Site name & Sample colle & ection & $\begin{array}{c}\text { Sele- } \\
\text { nium, } \\
\text { dissolved } \\
(\mu \mathrm{g} / \mathrm{L})\end{array}$ & $\begin{array}{c}\text { Silver, } \\
\text { dis- } \\
\text { solved } \\
(\mu \mathrm{g} / \mathrm{L})\end{array}$ & $\begin{array}{c}\text { Strontium, } \\
\text { dissolved } \\
(\mu g / L)\end{array}$ & $\begin{array}{l}\text { Vana- } \\
\text { dium, } \\
\text { dis- } \\
\text { solved } \\
(\mu \mathrm{g} / \mathrm{L})\end{array}$ & $\begin{array}{c}\text { Zinc, dis- } \\
\text { solved } \\
(\mu \mathrm{g} / \mathrm{L})\end{array}$ & $\begin{array}{l}\text { Gross- } \\
\text { alpha } \\
\text { radio- } \\
\text { activity } \\
\text { (pCi/L) }\end{array}$ & $\begin{array}{c}\text { Gross- } \\
\text { beta } \\
\text { radio- } \\
\text { activity, } \\
\text { (pCi/L) }\end{array}$ & $\begin{array}{l}\text { Uranium, } \\
\text { natural, } \\
\text { dis- } \\
\text { solved } \\
((\mu \mathrm{g} / L)\end{array}$ & $\begin{array}{c}\text { Organic } \\
\text { carbon, } \\
\text { dis- } \\
\text { solved } \\
\text { (mg/L) }\end{array}$ \\
\hline \multicolumn{12}{|c|}{ Main-stem sites } \\
\hline PC0 & $12-07-00$ & 1040 & nd & nd & 2,880 & nd & 1.6 & nd & nd & nd & nd \\
\hline PC180 & $12-07-00$ & 1035 & nd & nd & 2,940 & nd & 2.0 & nd & nd & nd & nd \\
\hline PC420 & $12-07-00$ & 1030 & nd & nd & 2,970 & nd & 2.3 & nd & nd & nd & nd \\
\hline PC660 & $12-07-00$ & 1020 & nd & nd & 2,910 & nd & 2.5 & nd & nd & nd & nd \\
\hline PC 1,080 & $12-07-00$ & 1015 & nd & nd & 2,950 & nd & 1.8 & nd & nd & nd & nd \\
\hline PC1,320 & $12-07-00$ & 1005 & nd & nd & 3,050 & nd & 2.1 & nd & nd & nd & nd \\
\hline PC 1,560 & $12-07-00$ & 0955 & nd & nd & 2,990 & nd & 2.0 & nd & nd & nd & nd \\
\hline PC 1,960 & $12-07-00$ & 0945 & nd & nd & 3,000 & nd & 1.8 & nd & nd & nd & nd \\
\hline PC2,205 & $12-07-00$ & 0935 & e 1.5 & $<1$ & 3,020 & e 4.2 & 2.3 & 3.1 & $<4.0$ & 3.5 & 3.6 \\
\hline PC2,445 & $12-07-00$ & 0925 & nd & nd & 3,010 & nd & 2.3 & nd & nd & nd & nd \\
\hline PC2,685 & $12-07-00$ & 0920 & nd & nd & 3,030 & nd & 2.3 & nd & nd & nd & nd \\
\hline PC2,925 & $12-07-00$ & 0910 & nd & nd & 3,100 & nd & 1.5 & nd & nd & nd & nd \\
\hline PC 3,105 & $12-07-00$ & 0900 & nd & nd & 3,100 & nd & 1.8 & nd & nd & nd & nd \\
\hline PC 3,278 & $12-07-00$ & 0845 & nd & nd & 3,080 & nd & 2.0 & nd & nd & nd & nd \\
\hline PC3,505 & $12-07-00$ & 0835 & nd & nd & 3,040 & nd & 1.5 & nd & nd & nd & nd \\
\hline PC 3,735 & $12-07-00$ & 0825 & nd & nd & 3,070 & nd & 1.7 & nd & nd & nd & nd \\
\hline
\end{tabular}


Table 5. Chemical data for synoptic samples collected in Piceance Creek Basin, December 4-7, 2000-Continued [mg/L, milligrams per liter; $\mathrm{HCO}_{3}$, bicarbonate; $\mathrm{CaCO}_{3}$, calcium carbonate; nd, no data; mv, missing value; e, estimated; <, less than; $\mu \mathrm{g} / \mathrm{L}$, microgram per liter; $\mathrm{pCi} / \mathrm{L}$, picocurie per liter]

\begin{tabular}{|c|c|c|c|c|c|c|c|c|c|c|c|}
\hline Site name & Sample cc & ection & $\begin{array}{c}\text { Sele- } \\
\text { nium, } \\
\text { dissolved } \\
(\mu \mathrm{g} / \mathrm{L})\end{array}$ & $\begin{array}{l}\text { Silver, } \\
\text { dis- } \\
\text { solved } \\
(\mu \mathrm{g} / \mathrm{L})\end{array}$ & $\begin{array}{c}\text { Strontium, } \\
\text { dissolved } \\
(\mu \mathrm{g} / \mathrm{L})\end{array}$ & $\begin{array}{l}\text { Vana- } \\
\text { dium, } \\
\text { dis- } \\
\text { solved } \\
(\mu \mathrm{g} / \mathrm{L})\end{array}$ & $\begin{array}{c}\text { Zinc, dis- } \\
\text { solved } \\
(\mu \mathrm{g} / \mathrm{L})\end{array}$ & $\begin{array}{l}\text { Gross- } \\
\text { alpha } \\
\text { radio- } \\
\text { activity } \\
\text { (pCi/L) }\end{array}$ & $\begin{array}{l}\text { Gross- } \\
\text { beta } \\
\text { radio- } \\
\text { activity, } \\
\text { (pCi/L) }\end{array}$ & $\begin{array}{l}\text { Uranium, } \\
\text { natural, } \\
\text { dis- } \\
\text { solved } \\
((\mu \mathrm{g} / \mathrm{L})\end{array}$ & $\begin{array}{c}\text { Organic } \\
\text { carbon, } \\
\text { dis- } \\
\text { solved } \\
\text { (mg/L) }\end{array}$ \\
\hline \multicolumn{12}{|c|}{ Main-stem sites-Continued } \\
\hline PC3,935 & $12-07-00$ & 0815 & nd & nd & 2,990 & nd & 1.9 & nd & nd & nd & nd \\
\hline PC4, 180 & $12-07-00$ & 0800 & $<2.4$ & $<1$ & 3,390 & e 7.5 & 1.9 & 3.8 & $<4.0$ & 3.5 & 3.9 \\
\hline PC4,420 & $12-07-00$ & 0755 & nd & nd & 2,940 & nd & 1.5 & nd & nd & nd & nd \\
\hline PC4,660 & $12-07-00$ & 0745 & nd & nd & 3,000 & nd & 2.0 & nd & nd & nd & nd \\
\hline PC4,900 & $12-07-00$ & 0735 & nd & nd & 3,040 & nd & 2.4 & nd & nd & nd & nd \\
\hline PC5,040 & $12-07-00$ & 0727 & nd & nd & 2,930 & nd & 1.9 & nd & nd & nd & nd \\
\hline PC5,280 & $12-07-00$ & 0700 & $<2.4$ & $<1$ & 3,140 & e 6.9 & 2.0 & 5.0 & $<4.0$ & 3.5 & 3.7 \\
\hline PC6,625 & $12-07-00$ & 1147 & na & na & 2,960 & na & 1.6 & na & na & na & na \\
\hline PC6,625 & $12-05-00$ & 1040 & nd & nd & 2,970 & nd & 2.2 & nd & nd & nd & nd \\
\hline PC6,813 & $12-05-00$ & 1020 & na & na & 2,970 & na & 1.6 & na & na & na & na \\
\hline PC7,028 & $12-05-00$ & 1010 & na & na & 3,020 & na & 1.3 & na & na & na & na \\
\hline PC7,248 & $12-05-00$ & 0955 & na & na & 3,070 & na & 2.0 & na & na & na & na \\
\hline PC7,498 & $12-05-00$ & 0945 & na & na & 2,990 & na & 2.5 & na & na & na & na \\
\hline PC7,738 & $12-05-00$ & 0935 & na & na & 3,020 & na & 1.6 & na & na & na & na \\
\hline PC7,978 & $12-05-00$ & 0930 & na & na & 3,060 & na & 1.8 & na & na & na & na \\
\hline PC 8,098 & $12-05-00$ & 0915 & e 1.4 & $<1$ & 3,350 & e 6.4 & 2.2 & 3.8 & $<4.0$ & 3.6 & 3.8 \\
\hline PC8,448 & $12-05-00$ & 0905 & na & na & 3,060 & na & 2.1 & na & na & na & na \\
\hline PC8,688 & $12-05-00$ & 0855 & na & na & 3,020 & na & 1.5 & na & na & na & na \\
\hline PC8,938 & $12-05-00$ & 0850 & na & na & 2,980 & na & 2.2 & na & na & na & na \\
\hline PC9,298 & $12-05-00$ & 0825 & na & na & 2,950 & na & 2.3 & na & na & na & na \\
\hline PC9,608 & $12-05-00$ & 0815 & na & na & 2,900 & na & 1.1 & na & na & na & na \\
\hline PC9,938 & $12-05-00$ & 0805 & na & na & 2,990 & na & 1.4 & na & na & na & na \\
\hline PC 10,328 & $12-05-00$ & 0800 & na & na & 2,880 & na & 2.8 & na & na & na & na \\
\hline PC 10,748 & $12-05-00$ & 0745 & na & na & 2,930 & na & 1.9 & na & na & na & na \\
\hline $\mathrm{PC} 11,483$ & $12-05-00$ & 0730 & $<2.4$ & $<1$ & 3,120 & e 4.7 & 1.6 & $<3.0$ & 8.8 & 3.6 & 3.9 \\
\hline $\mathrm{PC} 14,789$ & $12-06-00$ & 1005 & na & na & 2,980 & na & 1.7 & na & na & na & na \\
\hline $\mathrm{PC} 16,210$ & $12-06-00$ & 0910 & na & na & 3,000 & na & 2.4 & na & na & na & na \\
\hline $\mathrm{PC} 17,860$ & $12-06-00$ & 0805 & e 1.6 & $<1$ & 3,050 & e 5.0 & 1.3 & 4.3 & $<4.0$ & 3.8 & 4.0 \\
\hline PC20,708 & $12-06-00$ & 1030 & na & na & 2,810 & na & 2.0 & na & na & na & na \\
\hline PC23,721 & $12-06-00$ & 0945 & $<2.4$ & $<1$ & 2,860 & e 6.2 & 1.5 & 3.0 & $<4.0$ & 3.7 & 4.3 \\
\hline PC24,787 & $12-06-00$ & 0900 & na & na & 2,840 & na & 1.9 & na & na & na & na \\
\hline PC28,348 & $12-06-00$ & 0745 & na & na & 2,880 & na & 1.6 & na & na & na & na \\
\hline \multicolumn{12}{|c|}{ Input sites } \\
\hline RGS & $12-04-00$ & 0900 & na & na & 6,930 & na & 6.0 & na & na & na & na \\
\hline HGS & $12-07-00$ & 1220 & na & na & 3,000 & na & 2.0 & na & na & na & na \\
\hline PT16,225 & $12-06-00$ & 0925 & na & na & 1,590 & na & $<1.0$ & na & na & na & na \\
\hline AFS & $12-04-00$ & 1225 & na & na & 4,070 & na & 6.7 & na & na & na & na \\
\hline
\end{tabular}


Table 6. Comparison of selected constituent concentrations for duplicate water-quality samples collected in Piceance Creek Basin, December 4-7, 2000

[RPD, relative percent difference; $\mathrm{mg} / \mathrm{L}$, milligram per liter; $\mu \mathrm{g} / \mathrm{L}$, microgram per liter; NA, not applicable]

\begin{tabular}{|c|c|c|c|c|c|c|c|c|}
\hline \multirow{2}{*}{$\begin{array}{l}\text { Dissolved } \\
\text { constituent }\end{array}$} & \multicolumn{2}{|c|}{$\begin{array}{c}\text { Site } P C 3,305 \\
12 / 7 / 00 \text { at } 0835 \text { and } 0836\end{array}$} & \multicolumn{2}{|c|}{$\begin{array}{c}\text { Site } P C 8,448 \\
12 / 5 / 00 \text { at } 0905 \text { and } 0906\end{array}$} & \multicolumn{2}{|c|}{$\begin{array}{c}\text { Site BURKE }^{\top} \\
12 / 4 / 00 \text { at } 1035 \text { and } \\
1036\end{array}$} & \multicolumn{2}{|c|}{$\begin{array}{c}\text { Site PC28,348 } \\
12 / 6 / 00 \text { at } 0745 \text { and } \\
0746\end{array}$} \\
\hline & $\begin{array}{l}\text { Concen- } \\
\text { tration }\end{array}$ & $\operatorname{RPD}^{(2)}$ & $\begin{array}{l}\text { Concen- } \\
\text { tration }\end{array}$ & $\mathrm{RPD}^{(2)}$ & $\begin{array}{l}\text { Concen- } \\
\text { tration }\end{array}$ & $\mathrm{RPD}^{(2)}$ & $\begin{array}{l}\text { Concen- } \\
\text { tration }\end{array}$ & $\mathrm{RPD}^{(2)}$ \\
\hline \multirow[t]{2}{*}{ Calcium, mg/L } & 92 & 0 & 87 & 0 & 54 & 0 & 82 & 0 \\
\hline & 92 & & 87 & & 54 & & 82 & \\
\hline \multirow[t]{2}{*}{ Magnesium, mg/L } & 84 & 0 & 87 & 1.1 & 68 & 0 & 87 & 0 \\
\hline & 84 & & 86 & & 68 & & 87 & \\
\hline \multirow[t]{2}{*}{ Potassium, mg/L } & 2.4 & 4.1 & 2.6 & 8.0 & 1.4 & 0 & 2.6 & 0 \\
\hline & 2.5 & & 2.4 & & 1.4 & & 2.6 & \\
\hline \multirow[t]{2}{*}{ Chloride, $\mathrm{mg} / \mathrm{L}$} & 16 & 0 & 18 & 0 & 8.1 & 0 & 34 & 0 \\
\hline & 16 & & 18 & & 8.1 & & 34 & \\
\hline \multirow[t]{2}{*}{ Silica, mg/L } & 18 & 11 & 18 & 5.7 & 20 & 0 & 17 & 6.1 \\
\hline & 16 & & 17 & & 20 & & 16 & \\
\hline \multirow[t]{2}{*}{ Sulfate, $\mathrm{mg} / \mathrm{L}$} & 420 & 0 & 420 & 0 & 340 & 0 & 420 & 0 \\
\hline & 420 & & 420 & & 340 & & 420 & \\
\hline \multirow[t]{2}{*}{ Aluminum, $\mu \mathrm{g} / \mathrm{L}$} & 5.8 & 19 & 1.3 & 7.4 & $<1$ & NA & 1.2 & 70 \\
\hline & 7.0 & & 1.4 & & $<1$ & & 2.5 & \\
\hline \multirow[t]{2}{*}{ Barium, $\mu \mathrm{g} / \mathrm{L}$} & 73 & 1.4 & 78 & 0 & 38 & 0 & 100 & 0 \\
\hline & 74 & & 78 & & 38 & & 100 & \\
\hline \multirow[t]{2}{*}{ Boron, $\mu \mathrm{g} / \mathrm{L}$} & 170 & 0 & $190^{\circ}$ & 0 & 120 & 0 & 260 & 8.0 \\
\hline & 170 & & 190 & & 120 & & 240 & \\
\hline \multirow[t]{2}{*}{ Strontium, $\mu \mathrm{g} / \mathrm{L}$} & 3,040 & 0 & 3,060 & 1.7 & 2,060 & .5 & 2,880 & 1.0 \\
\hline & 3,040 & & 3,010 & & 2,070 & & 2,850 & \\
\hline \multirow[t]{2}{*}{ Bromide, $\mathrm{mg} / \mathrm{L}$} & 1.59 & 11 & 1.98 & 6.2 & .07 & 13 & .18 & 0 \\
\hline & 1.43 & & 1.86 & & .08 & & .18 & \\
\hline
\end{tabular}

The site BURKE was a domestic well. Although the site is not incorporated in the text of the report, these data do provide an adequate measurement of sample bias and are included in this table.

${ }^{2}$ Relative percent difference is calculated by dividing the absolute value of the concentration difference by the mean of the concentrations. The quotient is shown as a percentage. 
Table 7. Water-quality data for field blanks processed December 5 and December 7, 2000

\begin{tabular}{lcc}
\hline \multicolumn{1}{c}{$\begin{array}{c}\text { Field parameter } \\
\text { or } \\
\text { dissolved constituent }\end{array}$} & $\begin{array}{c}\text { Processed after } \\
\text { site PC8,098 } \\
\mathbf{1 2 / 5 / 0 0 ~ a t ~ 0 9 1 5 ~}\end{array}$ & $\begin{array}{c}\text { Processed after } \\
\text { site PC2,205 } \\
\mathbf{1 2 / 7 / 0 0} \text { at 0935 }\end{array}$ \\
\hline pH, standard unit & 7.7 & 7.9 \\
Specific conductance, microsiemens per centimeter & 3.9 & 4.0 \\
Calcium, milligram per liter & $<.011$ & .011 \\
Magnesium, milligram per liter & $<.008$ & $<.008$ \\
Sodium, milligram per liter & $<.06$ & $<.06$ \\
Potassium, milligram per liter & $<.09$ & $<.09$ \\
Alkalinity, milligram per liter & 2.0 & 1.6 \\
Sulfate, milligram per liter & $<.11$ & $<.11$ \\
Chloride, milligram per liter & $<.08$ & $<.08$ \\
Fluoride, milligram per liter & $<.16$ & $<.16$ \\
Silica, milligram per liter & $<.48$ & $<.48$ \\
Aluminum, microgram per liter & $<1$ & 6.3 \\
Antimony, microgram per liter & $<.048$ & $<.048$ \\
Arsenic, microgram per liter & $<.18$ & $<.18$ \\
Barium, microgram per liter & $<1$ & $<1$ \\
Boron, microgram per liter & $<13$ & $<13$ \\
Iron, microgram per liter & $<10$ & $<10$ \\
Strontium, microgram per liter & $<.8$ & $<.8$ \\
Zinc, microgram per liter & $<1$ & 5.1 \\
\hline
\end{tabular}




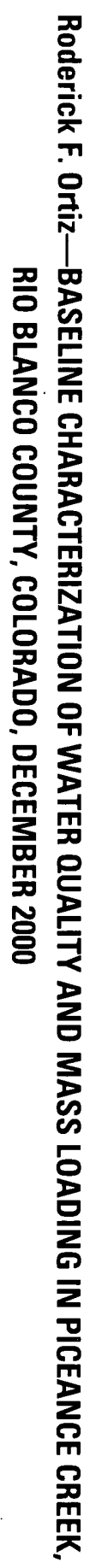

83 Printed on recycled paper 